C7- Uy

A Directory of

Crocodilian Farming

Operations

Display copy do net cenove

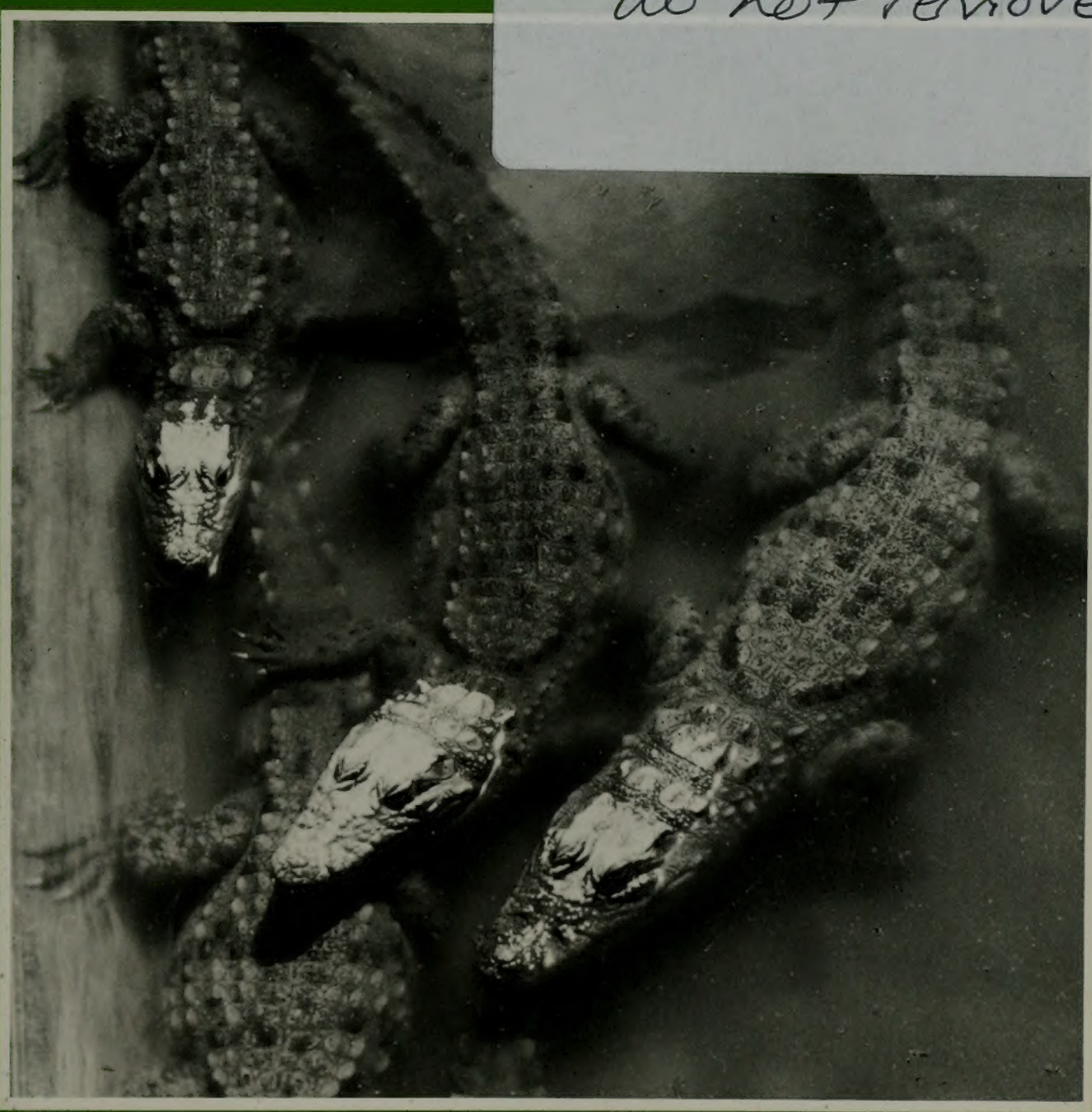





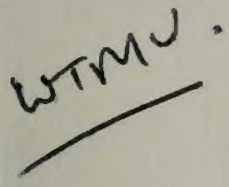

A Directory of Crocodilian Farming Operations 



\title{
A Directory of Crocodilian Farming Operations
}

\author{
Répertoire des élevages de crocodiliens
}

\section{Una guía de criaderos de cocodrilos}

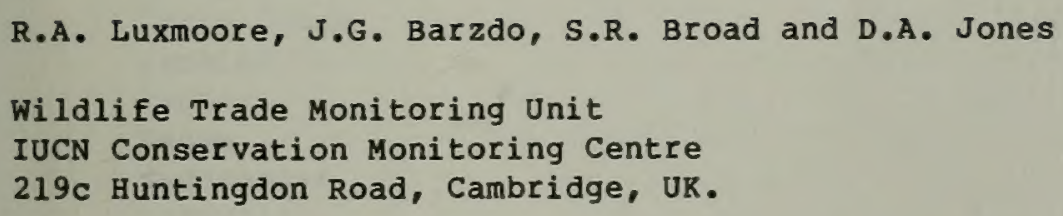


A joint publication of the International Union for Conservation of Nature and Natural Resources (IUCN), Gland, Switzerland and Cambridge, U.K. and the Secretariat of the Convention on International Trade in Endangered Species of Wild Fauna and Flora, Lausanne, Switzerland. 1985.

The publishers acknowledge the financial support of the International Fur Trade Federation in the preparation of this report.

(C) International Union for Conservation of Nature and Natural Resources 1985

ISBN 2-88032-809-8

Printed in Great Britain at the University Press, Cambridge.

Cover photo:WWF/Gerald Cubitt. Mugger Crocodiles Crocodylus palustris at breeding station in Sasan Gir, Gujarat, India.

Cover design by James Butler

The presentation of material in this document and the geographical designations employed do not imply the expression of any opinion whatsoever on the part of IUCN or CITES concerning the legal status of any country, territory, or area, or concerning the delimitation of its frontiers or boundaries. 


\section{CONTENTS}

\begin{tabular}{|c|c|c|}
\hline Introductio & & 1 \\
\hline Introductio & n Francais & 11 \\
\hline Introduccio & n Espagnol & 23 \\
\hline Tables & & 35 \\
\hline CITES Resol & utions & 41 \\
\hline Australia & Northern Territory & 51 \\
\hline Australia & Queensland & 55 \\
\hline Bangladesh & & 59 \\
\hline Bolivia & & 60 \\
\hline Botswana & & 61 \\
\hline Brazil & & 62 \\
\hline Brunei & & 63 \\
\hline Burma & & 64 \\
\hline Cameroon & & 65 \\
\hline Chad & & 66 \\
\hline China & & 67 \\
\hline Colombia & & 71 \\
\hline Costa Rica & & 72 \\
\hline Cuba & & 73 \\
\hline Ethiopia & & 75 \\
\hline France & & 76 \\
\hline Greece & & 77 \\
\hline India & & 78 \\
\hline Indonesia & General Information & 81 \\
\hline Indonesia & Irian Jaya & 84 \\
\hline Indonesia & Java & 91 \\
\hline Indonesia & Sumatra & 93 \\
\hline Indonesia & Kalimantan \& Mentawai & 94 \\
\hline Israel & & 95 \\
\hline Italy & & 97 \\
\hline Ivory Coast & & 98 \\
\hline Jamaica & & 99 \\
\hline Japan & & 100 \\
\hline Kenya & & 101 \\
\hline Madagascar & & 103 \\
\hline Malaysia & & 106 \\
\hline Mali & & 109 \\
\hline Mauritius & & 110 \\
\hline Mexico & & 111 \\
\hline Mozambique & & 115 \\
\hline Nepal & & 116 \\
\hline Pakistan & & 118 \\
\hline Papua New G & Suinea & 119 \\
\hline PNG Commer & cial ranches & 122 \\
\hline Philippines & & 129 \\
\hline Rwanda & & 131 \\
\hline Senegal & & 132 \\
\hline Singapore & & 133 \\
\hline South Afric & ca Cape Province & 136 \\
\hline South Afric & ca Natal & 111 \\
\hline South Afric & ca Transvaal & 142 \\
\hline
\end{tabular}


Spain

Sri Lanka

Suriname

Taiwan

Tanzania

Thai land

Togo

Uganda

United States General

United States Louisiana

United States Florida

162

Uruguay

170

Venezuela

Western Samoa

Zambia

Zimbabwe General

Zimbabwe The Operations

References 
Crocodilians have long been exploited commercially for their skins which attract a high price. Until relatively recently the demand for skins was met exclusively from the hunting of wild populations, but in the last few years a great expansion has taken place in the farming of crocodilians. The earliest so-called "farms" were undoubtedly for the purpose of public display, more in the nature of zoos, and many today still fulfil this role. However farming for the commercial production of skins is increasingly being practised. Some farms also sell crocodile meat and, as in Taiwan, this may occasionally provide the major source of income.

The reasons for the rise in popularity of the farming of crocodilians are difficult to assess, but they undoubtedly include the reduction in the supply of wild skins. In part this has been due to a decline in wild populations through over-hunting, persecution and habitat destruction, but legal controls may have been more important. Chief amongst these is the Convention on International Trade in Endangered Species of Wild Fauna and Flora (CITES). The majority of crocodilians are in Appendix I of CITES (see Table 1) which means that nearly all commercial trade between party nations is prohibited unless the specimens derive from captive-bred populations. Since the Convention came into force, in 1975, the efficacy of the controls on trade has been increasing as more countries have become party to the Convention and as enforcement procedures have improved. The demand for the higher value "classic" crocodilian skins, especially those of Crocodylus niloticus and Crocodylus porosus, has remained high and, as other legal sources of skins have been shut off, farming appears to have prospered.

This directory of crocodilian farming operations was compiled partially to assist in the enforcement of CITES controls, by identifying captive-breeding operations and so-called "farms" which are not breeding crocodilians, and also to ascertain the extent of farming so that its effect on crocodilian conservation can be assessed. It attempts to list all commercial crocodilian farms, giving details of their stock, production, breeding success and husbandry. The survey was designed primarily to locate commercial farming operations but large conservation-orientated crocodilian-breeding centres have also been included, partially because some may develop into commercial farms in the future. Proposed plans for commercial farming have also received attention for the same reason. In this directory the term "farm" has been used to denote any operation rearing crocodilians in captivity; it therefore includes both ranches, which obtain stock from the wild, and captive-breeding operations. Crocodilians are kept, and regularly breed, in zoos around the world, but these have not been considered.

It must be stressed that the listing of a farm in this directory does not in any way imply that the farm meets the requirements of CITES for recognition as a captive-breeding operation. This function is fulfilled by the register of such operations 
maintained by the crTes secretariat, as explained in the following section.

\section{CITES controls on trade}

Because CITES controls are so important to the understanding of the farming of crocodilians, and because so much confusion surrounds their interpretation, the following section is provided as a summary of the requirements in relation to trade in crocodilian products.

All trade involving countries party to the Convention is subject to the terms of the Convention unless it involves products acquired prior to the Convention's coming into force or unless the country holds a reservation for the species involved, in which case it is treated as a non-Party. Countries currently holding reservations on crocodilians are shown in Table 1. Other countries, notably Italy and France, have held reservations in the past, but these have now been withdrawn.

All crocodilians are afforded protection under the Convention by being listed in either Appendix I or Appendix II.

Appendix I lists those taxa which are threatened with extinction which are, or may be, affected by trade. Virtually all international trade in these species is prohibited unless the exporting Party grants an export permit. This may only be done if the trade is not detrimental to the survival of the wild population and if a permit has been issued by the importing Party stating that the animals or products are not to be used for primarily commercial purposes. There are few exceptions to this, the major one being if the animals traded derive from populations bred in captivity in accordance with the conditions described below. Such animals are treated as being in Appendix II.

Appendix II lists those taxa in which trade must be subject to strict regulation in order to prevent them, or similar species in the list, becoming threatened with extinction in the future. Trade is therefore permitted only when the exporting country issues an export permit indicating that the trade is not detrimental to the survival of the wild population.

Countries which are party to the Convention must treat non-party states more or less as if they were also Parties. In other words, if a trader in a party state wants to import a species in Appendix II from a non-Party then he must obtain a cITES-equivalent export permit.

\section{Captive-breeding}

The conditions under which specimens of an Appendix I species may be considered "captive-bred" were defined at the CITES Meeting in San José, Costa Rica, in 1979 and are set out in CITES Resolution Conf. 2.12. Briefly these state that: 
1. Animals may only be traded as captive-bred if they are born in captivity and are the offspring of parents which mated in captivity (or a "controlled environment").

2. The parental breeding stock must be (i) obtained in a manner not detrimental to the survival of the species in the wild; (ii) maintained without augmentation from the wild population except for occasional introductions for the purposes of genetic improvement; and (iii) managed in a manner which has been demonstrated to be capable of reliably producing second generation captive-bred offspring.

It should be noted that second generation offspring do not actually need to have been produced on the farm provided it is using a husbandry technique which has been demonstrated elsewhere to have been capable of producing such offspring.

\section{Register of captive-breeding operations}

These regulations are open to abuse by unscrupulous dealers who merely collect animals from the wild and sell them, claiming that they were captive-bred. There is therefore a need for an authoritative register of approved operations which are producing captive-bred Appendix I species. This need was recognised at the CITES Meeting in Gabarone, Botswana, in 1983 when a Resolution (Conf. 4.15) was adopted recommending that commercial trade in cantive-bred Appendix I species should only be permitted from operations which are registered with the CITES Secretariat. Registration is achieved when the CITES Management Authority in the country of origin reports to the secretariat details of the farm (specified in CITES Notification to the Parties No. 233, 13 october 1983) and confirms that it complies with conditions set out in Resolution Conf. 2.12. At the date of going to press there are only five registered operations breeding Appendix I crocodilians, one in Madagascar, one in Queensland, Australia, one in Thailand, and two in South Africa.

\section{Ranching}

It has been recognised that some populations of species in Appendix I have recovered as a result of conservation, and are now no longer endangered. They may be capable of sustaining a controlled level of exploitation, and indeed may even benefit from it. A procedure was therefore recommended at the CITES Meeting in New Delhi, India, in 1981, whereby populations of species in Appendix I which would benefit from ranching could be transferred to Appendix II (Conf. 3.15). Ranching is defined as the rearing in a controlled environment of specimens taken from the wild, for the purposes of trade. In order to be eligible, the ranching scheme must be beneficial to the wild population and the products of it must be marked so that they may be distinguished from the products of other populations of the same species in Appendix I.

It should be noted that, as there is potentially a continuous interchange between the ranch-reared and wild populations in the 
country, they are treated identically in the eyes of CITES and may both be traded. It is up to the local Management Authority to set regulations which differentiate between ranch-reared and wild-caught products. However a Resolution adopted in 1985 (Conf. 5.16) now requires that any conditions specified in the original ranching proposal must be observed by all parties trading in specimens from the ranched population. Thus since the Australian proposal for ranching $\mathrm{C}$. porosus states that the sale of skins from animals which have not been kept on a ranch for at least one year is prohibited, other Parties should not accept imports of such skins.

The population of $\mathrm{C}$. niloticus in $\mathrm{zimbabwe}$ was transferred to Appendix II in 1983 as a result of a ranching scheme, and the population of $\mathrm{C}$. porosus in Australia was transferred in 1985 under a similar scheme.

A further Resolution was adopted at Buenos Aires in 1985 on the trade in ranched specimens which recommended, among other things, that ranched products should not be exported to non-Parties nor to Parties holding reservations on the ranched species, and that imports of ranched products should not be accepted from such states. Some of the ramifications of this are that exports of ranched $C$. porosus skins should not be permitted from Australia to singapore, as it is a non-Party, nor to Japan, as it has a reservation on this species.

The Meeting at Buenos Aires, Argentina, was notable for a change in the procedure for transferring, from Appendix I to Appendix II, those species which had been listed in Appendix I before the agreement of scientific criteria for so doing, and which could withstand some exploitation. The new procedure involves the setting of a quota for each country wishing to trade in these species, in conjunction with an approved management plan. Under this procedure, the populations of $C$. niloticus in nine African countries listed in Table 2 were transferred to Appendix II with the quotas indicated. The population of $C$. porosus in Indonesia was transferred to Appendix II with an annual quota of 2000 skins, although in this case the population is still endangered (204).

Ranching programmes have many advantages over direct harvesting in that they permit a greater offtake from a given wild population, they produce higher quality skins and they are easier to police. They are, however, more difficult to set up and are more capital-intensive. It is therefore ironic that the developments at Buenos Aires have removed some of the economic advantages of establishing ranching programmes for Appendix I species, in that their potential markets are now restricted, while the quota system for transferring populations to Appendix II is permitted greater flexibility of marketing.

\section{METHODS}

The survey was undertaken during 1983 and 1984. The CITES Secretariat sent a Notification to all CITES Parties of the need to register all commercial captive-breeding operations involving Appendix 
I species. The Wildife Trade Monitoring Unit also approached the wildife management authorities of non-CITES governments. Contact was made with members of the SSC Crocodile Specialist Group, with crocodile farmers associations and with other individuals knowledgeable on the subject. Wherever possible, questionnaires were sent to the farms themselves requesting details of their stocks, breeding, wild capture, commercial production and husbandry. The results presented in this paper are drawn from the responses to these enquiries and also from published and unpublished material and press reports. In the directory the results are arranged by country.

\section{RESULTS AND DISCUSSION}

The countries and species mentioned in the text are listed in Table 3, which also indicates where commercial operations are found. The species most widely farmed are c. niloticus and c. porosus: this partially reflects their widespread distribution, but also the value of their skins, as they are both highly esteemed by the skin industry.

The numbers of the main species kept on commercial farms are shown in Table 4, where it can be seen that Alligator mississippiensis is probably the most numerous species although $C$. niloticus and $C$. porosus are kept in similar numbers, and the data on these species are less complete. The total number of farms is shown on Table 5 together with other data relating to their production. There are thought to be other farms, for instance in singapore and Malaysia, for which details were not obtained. Of the 152 farms known in 1985 fewer than 20 were in existence in 1974, and all the indications are that the rapid growth is continuing. The total crocodilian stock of 161603 is also evidently growing. Recruitment from the collection of wild animals and captive breeding is running at some 72000 a year.

As would be expected from such a young industry, skin production is relatively low while farmers are apparently attempting to build up their stocks. Prior to 1979 when the farms in Papua New Guinea started production the only appreciable quantities of skins being sold from farms originated in Zimbabwe. This survey has shown that at least $14769 \mathrm{farm}$ skins were marketed in 1983/84. If it is assumed that the majority of the recruitment to farm stocks is to be slaughtered in four years time, then production might rise to 60000 by 1989 , although it is unlikely that the growth will be so fast.

\section{Pinances}

Although legislative controls on hunting wild crocodilians undoubtedly play an important part in generating favourable conditions for the establishment of farms, the factor which will ultimately determine their continued survival is their financial success.

Commercial companies are understandably reluctant to release their accounts for scrutiny, and so it is difficult to assess their profitability. In addition most farms are currently in the development phase and would consequently be expected to be in negative cash balance 
until they reach full production. As a starting point it therefore seems reasonable to examine first the oldest-established farms.

One of the oldest farms in the world is the samutprakan farm in Thailand. In 1983 this was said to have a stock of some 30000 crocodilians, but produced only 200 skins. It could clearly not have been financially viable purely on skin sales, but the operation derives the major part of its income from tourists and claims to be selffinancing on this basis.

The farms in the USA similarly have a poor stock/production ratio, although they also sell meat as well as skins which may help to boost their profits. Some farms generate additional income by selling livestock to other farmers and some also rely partially on tourist income. A recent analysis (96) suggested that value of an animal at slaughter was US\$200-300 while production costs including feeding, labour and hatchling acquisition, were US\$85-110. This gives a calculated profit, after allowing for a 108 mortality, of US\$80-192 for each animal. Set against this are the capital investment costs, estimated to be US\$50 000-200 000 (40), the interest on which would be worth some US\$5000-20 000 a year for four years, before any production took place. On the most pessimistic estimates a farmer would therefore need to sell 345 animals merely to pay off his interest before starting to recoup any of his initial investment.

The growth in the number of farms in the USA was slow until 1982 and it has been suggested that the chief reason for farming was an interest in alligators, which could be indulged only by rich individuals not unduly interested in swift profits (123). However the rapid increase in the last two years in the number of farmers, particularly in Florida, suggests that substantial profits are expected, if not yet realised. This may be associated with the increasing availability of hatchlings from wild-collected eggs from Louisiana Rockefeller Refuge and, particularly, the Florida supplement programme.

The farms in zimbabwe also benefit from a state-run egg collection programme and Magnusson (123) attributes their apparent profitability to cheap labour and a plentiful supply of cheap protein food for the crocodiles, both of which he suggests may decline in the future. Several of these farms also derive a substantial part of their income from tourists and the sale of curios (179).

The crocodile ranching industry in Papua New Guinea provides a model which other countries are attempting to emulate and which contributes the bulk of the world production of farmed skins (Table 5). Although many of the small farms initially established have been discontinued, those that survive are apparently capable of running at a profit, almost exclusively on skin sales (85). An analysis of the proposed ranching industry in Australia, also using $C$. porosus, estimated that total acquisition and rearing costs per hatchling were A $\$ 35-55$ to a slaughter size of $5-6 \mathrm{ft}(1.52-1.83 \mathrm{~m})$, at which point the skins were valued at $\mathrm{A} \$ 150-180(192)$. 
It is clear that the captive-breeding of crocodilians requires more money, both in terms of the running costs of maintaining broodstock and in the initial capital outlay required to install breeding facilities, than the rearing of wild-caught eggs or young. Magnusson (123) has pointed out that the majority of the financially successful operations depend on wild populations of crocodilians for the bulk of their rearing stock. It is therefore slightly surprising that the farms in Zimbabwe and the USA are breeding increasing quantities of their own stock, and breeding is being investigated more seriously in Papua New Guinea. One possible explanation is that many captive-breeding operations rely, at least partially, on tourist income. Indeed the needs of tourists and of breeding facilities are similar, both requiring large, mature animals and semi-natural ponds; and the large sums invested in new tourist-orientated farms indicate that the financial backers, at least, anticipate making money from this type of venture.

\section{Crocodilian farming and its impact on conservation}

Controversy has raged over whether or not the farming of crocodilians may be desirable on conservation grounds. The arguments for and against farming may be sumnarised as follows:

\section{Diversion of trade}

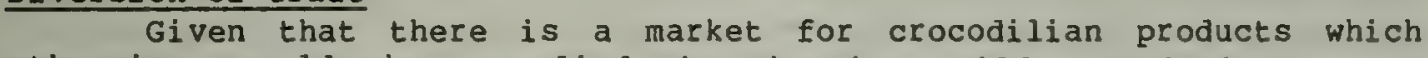
otherwise would be supplied by hunting wild populations, the availability of the same products from farmed stock may meet some of the demand and reduce the need for hunting. Whether this works in practice or whether farmed products merely add to the size of the market, is open to debate. The chief effect is likely to be economic, by reducing the price of skins and thereby reducing the profit margins of hunting to unacceptable levels. This effect is particularly marked where the hunting operation is poorly managed and the wild population is nearing "commercial extinction". Farmed skins tend to be of higher and more uniform quality than wild-caught ones which gives them a competitive advantage in the market, although they may consequently command a higher price.

In contrast it has been suggested that if illegal trade has been successfully reduced by control measures, public demand will also drop. Any renewed stimulation of the market by the introduction of farmed products will increase the demand once more and possibly renew hunting pressure on the wild populations. This effect is likely to be greatest where trade has virtually ceased, in general for species in Appendix I.

Both arguments are affected by the relative sizes of the supplies of farm-raised and wild-caught skins. International trade in crocodilian skins has recently been reviewed by Hemley and Caldwell (94) who found that trade in the major species, excluding Caiman crocodilus, reported to CITES was at least 82000 a year although they cautioned that this was certainly an under-estimate. Farm production of 12000 skins is already a significant proportion of this market, and its importance is destined to increase. However, the major trade is 
undoubtedly in c. crocodilus skins, some 700 thousand reported annually to cITEs with the true trade figure probably being in excess of a million (94). Taiwan is the only country farming this species in large numbers, primarily because the low commercial value of the skins means that farming is not economic unless other products can also be marketed. It is therefore unlikely that farming will ever supply a significant proportion of the world market for $C$. crocodilus, or for crocodilian skins as a whole, unless trade in wild-caught caiman skins is drastically curtailed.

\section{Control of trade}

Control of illegal trade in the products of endangered species is rendered more difficult by introducing legally acquired farmed products into the market. This problem has been addressed by the CITES Resolutions on both captive-breeding (Conf. 2.12) and ranching (Conf. 3.15) which recommend that the products be adequately marked to distinguish them from products of wild-taken animals. However it is still feared that unscrupulous traders may use farms as a front for disposal of illegally acquired, wild-caught skins, either directly from the farm or on re-export from an intermediate country. Several countries with crocodilian farming industries have elaborate licensing and inspection procedures designed to prevent this, but allegations of "laundering" illegal skins have certainly been levelled at some farms. This directory may be helpful in countering this problem as it has attempted to ascertain current stocking levels and breeding success. Any so-called farmed skin production in excess of known capacity or from countries not known to have farms should require further investigation.

\section{Effects on wild populations}

If a species has become depleted or even endangered in the wild, captive rearing may provide protection for a significant proportion of the population. If breeding can also be achieved, the population can be augmented until ultimately it may be possible to reintroduce captive-bred stock to the wild. Several crocodilian breeding operations have undoubtedly achieved this, notably with crocodylus moreletii, $c$. intermedius and Gavialis gangeticus, but these are all conservation operations and not intended to be commercial. The only comercial operation currently using a seriously endangered species, Crocodylus siamensis, is the Samutprakan farm in Thailand. The Zapata Swamp farm in Cuba also breeds Crocodylus rhombifer and $\mathrm{c}$. acutus but the degree of commercial involvement of this farm is not known. However it is by no means certain that reintroductions of farmed stock would be desirable because of genetic alteration, either through artificial selection or hybridization. Both the Samutprakan Farm and the zapata Swamp farm already have substantial populations of hybrid animals.

Captive-breeding is seldom completely independent of the wild population and the capture of wild animals is often necessary, if not for direct rearing, at least for the acquisition of breeding stock. Thus even captive-breeding operations usually result in a net drain, albeit small, on the wild stock. A fully developed ranching operation 
removes far more animals from the wild but, even if reintroductions are not carried out, one of the chief prerequisites for approval of a ranching scheme under the provisions of CITES Resolution Conf. 3.15 is that it should, on balance, be beneficial to the wild population, although this only affects those species in Appendix I.

\section{Habitat and species preservation}

Crocodilians have in the past been persecuted as vermin, and their swampy habitat is frequently destroyed to make way for "more productive" forms of land use. The demonstrable ability of crocodilians to generate income may help to promote the conservation of healthy wild populations. This is particularly so with ranching, where the whole operation depends on the maintenance of a wild breeding stock, but to a much lesser extent captive-breeding farms may encourage the conservation of wild stock for periodic genetic enhancement. The maintenance of a wild population of crocodilians necessitates the preservation of their habitat, which benefits the other organisms in the same environment. The financial incentive of crocodilian exploitation therefore also reduces the economic pressure for wetland reclamation.

\section{Cultural preservation}

Crocodilian ranching techniques can be adapted to conditions of village technology suitable for integration in the culture and economy of rural communities. The ranching progrinmes in Papua New Guinea and Northern Australia have the declared objectives of providing employment for indigenous peoples. Alternative schemes for the generation of income frequently entail far greater technological input and social disruption.

\section{Genetic mixing and disease risk}

other potential disadvantages include the accidental introduction of non-indigenous species or distinct genetic races from escapes, and the spread of disease from farm to wild stock.

\section{THE OUTLOOR}

In most countries that host a crocodilian farming industry it appears to be growing, in terms of the number of farms, the number of animals and the production of skins. The technical problems of farming have largely been surmounted, but whether this growth continues or whether the industry collapses will depend on its long-term financial viability. One factor which is of importance to the conservation of crocodilians is the relative reliance on wild-caught animals ("ranching") and on captive-breeding. The total number of animals being bred on farms appears to be increasing, and may now account for some 408 of recruitment to farm stocks each year. At first sight this might seem to be encouraging but this requires further consideration.

Captive-breeding has played an important role in the conservation of several seriously depleted crocodilian species, but these have mostly been non-commercial operations. Commercial 
captive-breeding, as discussed earlier, does less to further conservation, and it should not be seen, as it often is, as an alternative to habitat conservation. Ranching, on the other hand, may be far more beneficial as it requires the maintenance of a healthy wild population and the habitat which supports it (123). In essence it is little different from a controlled harvest of larger animals for skins; in the USA and Papua New Guinea the two types of exploitation run side by side. Ranching has some advantages over a direct harvest as it may be easier to regulate, particularly if, as in 2 imbabwe, the USA and Australia, the collection of eggs is carried out entirely by Government staff or under their close control. The maintenance of a separate ranched stock also provides a degree of insurance in the event of an environmental disaster or breakdown of effective control of harvesting, owing, for instance, to political instability.

The cause of crocodilian conservation may therefore best be served, not by a cessation of all wild harvesting and a development of farming, but by the implementation of effective management plans for wild populations, involving ranching, direct harvest, or a combination of the two. The success of any such management plan is entirely dependent on thorough background research to determine existing population levels, and on the ability to conduct the exploitation in a controlled manner. The high levels of illegal trade in crocodilian products (94) suggests that the current degree of control is far from adequate in many parts of the world.

\section{ACKNOWLEDGEMENTS}

Funds for this survey were generously provided by the International Fur Trade Federation and IUCN. This survey would have been quite impossible without the willing assistance and co-operation of the numerous correspondents who replied to letters and filled in questionnaires. Their help has been credited wherever possible in the references, and the authors would here like to express their gratitude. 


\section{INTRODUCTION}

Les crocodiliens sont exploités pour le commerce de leurs peaux qui atteignent des prix élevés. Jusqu'à une époque relativement récente, la demande de peaux était satisfaite exclusivement par la chasse des populations sauvages mais, ces dernières années, l'élevage des crocodiliens s'est fortement étendue. Les premières "fermes", selon l'appellation qui leur est donnée, ont sans aucun doute été crées à l'intention du public, ayant davantage la nature de zoos, et nombre d'entres elles continuent de jouer ce rôle. Cependant, l'élevage pour la production commerciale de peaux est de plus en plus pratiqué. Certaines fermes vendent aussi de la viande de crocodile et, comme à Taïwan, ceci peut parfois fournir la principale source de revenu.

Les raisons de cette popularité accrue de l'élevage des crocodiliens sont difficiles à évaluer, mais elles comprennent certainement la réduction apparue dans l'approvisionnement en peaux sauvages, Ceci est dû, en partie, au déclin des populations sauvages du fait d'une chasse excessive, de la persécution et de la destruction des habitats, mais les contrôles exercés en application des lois pourraient avoir une plus grande importance encore. En tête de ceux-ci se trouve la Convention sur le commerce international des espèces de faune et de flore sauvages menacées d'extinction (CITES). La majorité des crocodiliens sont inscrits à l'Annexe I de la Convention (voir Tableau 1), ce qui signifie que presque toutes les transactions commerciales entre les pays Parties sont interdites, à moins que les spécimens proviennent de populations élevées en captivité. Depuis l'entrée en vigueur de la Convention, en 1975, l'efficacité des contrôles du commerce s'est accrue, car davantage de pays en sont devenus Parties et les procédures d'exécution se sont améliorées. La demande de peaux "classiques" de crocodiliens les plus précieuses, tout spécialement celles des espèces crocodylus niloticus et crocodylus porosus, est restée forte et, les autres sources limitées de peaux ayant été fermées, l'élevage paraît avoir prospéré.

Ce répertoire des élevages de crocodiliens a été élaboré, en partie, pour faciliter l'exécution des contrôles cITEs, en identitiant les élevages et les soi-disantes "fermes" qui ne procèdent pas à la reproduction, et aussi pour déterminer l'importance de l'élevage, en vue d'évaluer ses effets sur la conservation des crocodiliens. Il tente d'établir une liste de toutes les fermes commerciales de crocodiliens et donne des informations détaillées sur leur cheptel, leur production, leur réussite en matière de reproduction et sur les techniques d'élevage. L'enquête a été conçue, en premier lieu, afin de localiser les élevages comnerciaux, mais les grands centres de reproduction de crocodiliens orientés vers la conservation $y$ ont aussi été inclus, notamment parce que certains pourraient devenir des élevages commerciaux à l'avenir. Pour la même raison, l'attention a également été portée sur les projets d'élevages commerciaux. Dans ce répertoire, le terme "ferme" est utilisé pour désigner tout élevage, au sens le plus large du terme, en captivité (soit la détention pendant au moins une certaine période); il comprend donc les ranches dont le cheptel a été prélevé à l'état sauvage et les élevages qui 
pratiquent la reproduction en captivité. Des crocodiliens sont gardés dans des zoos du monde entier, où ils se reproduisent, mais ils n'ont pas été pris en considération.

Il faut souligner que l'inscription d'un élevage dans ce répertoire n'implique en aucune façon que la ferme satisfait aux exigences cITES qui lui permettraient d'être reconnue en tant qu'élevage en captivité. Ce rôle est rempli par le Registre des établissements pratiquant l'élevage en captivité tenu par le Secrétariat CITES, ainsi qu'il est expliqué dans la section suivante.

\section{Contrôles CITES du commerce}

Etant donné l'importance des contrôles cITes pour comprendre le pourquoi de l'élevage des crocodiliens et en raison de la confusion qui règne au sujet de leur interprétation, la section qui suit est rédigée en tant que résumé des exigences relatives au commerce des produits de crocodiliens.

Tout le commerce qui concerne des pays Parties à la Convention est soumis aux dispositions de celle-ci, à moins gu'il ne se rapporte à des spécimens acquis avant que la Convention soit entrée en vigueur ou à moins que le pays ait formulé une réserve à l'égard de l'espèce en question, auquel cas ce pays est considéré comne un Etat non-Partie. Les pays qui ont formulé des réserves à l'égard de crocodiliens sont mentionnés dans le Tableau 1. D'autres pays, notamment l'Italie et la France, avaient des réserves dans le passé, mais elles les ont maintenant retirées.

Tous les crocodiliens bénéficient d'une protection au titre de la Convention, car ils sont inscrits soit à l'Annexe I, soit à l'Annexe II.

A l'Annexe I sont inscrits les taxions menacés d'extinction qui sont affectés par le commerce, ou qui pourraient l'être. Pratiquement tout le commerce international de ces espèces est interdit, à moins que la Partie exportatrice délivre un permis d'exportation. Ceci ne peut se faire que si le commerce ne nuit pas à la survie de la population sauvage et si un permis a été délivré par la Partie importatrice qui déclare ainsi que les animaux ou les produits ne seront pas utilisés à des fins principalement commerciales. Il y a quelques exceptions, la principale concernant le commerce d'animaux provenant de populations élevées en captivité conformément aux conditions décrites ci-dessous. Ces animaux sont traités comme s'ils étaient inscrits à l'Annexe'II.

A l'Annexe II sont inscrits les taxons dont le commerce doit être soumis à une réglementation stricte ayant pour but d'éviter qu'eux, ou des espèces semblables de cette même annexe, ne deviennent menacés d'extinction à l'avenir. Le commerce n'est donc permis que lorsque le pays d'exportation délivre un permis d'exportation, ce qui signifie que le commerce ne nuit pas à la survie de la population sauvage. 
Les pays qui sont Parties à la convention doivent traiter les Etats non-Parties plus ou moins comme s'ils étaient aussi des Parties. En d'autres termes, si un commerçant d'un Etat Partie souhaite importer une espèce de l'Annexe II d'un Etat non-Partie, il doit obtenir un document équivalent au permis d'exportation CITES.

\section{Elevage en captivité}

Les conditions dans lesquelles des spécimens d'une espèce inscrite à I'Annexe I peuvent être considérés comne "élevés en captivité" ont été définies lors de la session CITES de San José, Costa Rica, en 1979 et elles sont présentées dans la résolution CITES Conf. 2.12. En bref, elles sont les suivantes:

1. Des animaux ne peuvent être commercialisés en tant que spécimens élevés en captivité que s'ils sont nés en captivité et sont les descendants de parents s'étant accouplés en captivité (ou dans un "environnement contrôlé).

2. Le stock parental doit être (i) obtenu de façon à ne pas nuire à la survie de l'espèce à l'état sauvage: (ii) maintenu sans augmentation à partir de la population sauvage à l'exception d'apports occasionnels aux fins d'amélioration génétique; et (iii) gérés d'une manière ayant apporté la preuve qu'elle permet de pruduire de façon sûre une descendance de deuxième génération.

Il convient de remarquer qu'il n'est pas nécessaire de produire une descendance de deuxième génération dans l'établissement, à condition que les techniques qu'il applique aient fourni la preuve, ailleurs, qu'elles permettent de produire une telle descendance.

\section{Registre des établissements pratiquant l'élevage en captivité}

Des commerçants peu scrupuleux peuvent abuser de ces réglementations en prélevant simplement des animaux à l'état sauvage et en les vendant en prétendant qu'ils ont été élevés en captivité. Il est donc nécessaire d'avoir un registre faisant foi des élevages agréés qui produisent des spécimens d'espèces de l'Annexe I élevés en captivité. Ce besoin fut reconnu à la session CITES de Gaborone, Botswana, en 1983, où une résolution (Conf.'4.15) a été adoptée pour recommander que les transactions commerciales touchant les espèces de l'Annexe I élevées en captivité ne soient autorisées que pour des établissements enregistrés auprès du secrétariat cITES. L'enregistrement est effectif lorsque l'organe de gestion cITES du pays d'origine a transmis au secrétariat des informations détaillées au sujet de la ferme (information précisées dans la notification aux Parties No. 233 du 13 octobre 1983) et a confirmé qu'elle respecte les conditions présentées dans la résolution Conf. 2.12. A la mise sous presse de ce répertoire, seuls cinq établissements élevant des crocodiliens inscrits à l'Annexe I avaient été enregistrés, un à Madagascar, un au Queensland, Australie, un en Thaillande et deux en Afrique du sua. 
Le fait a été admis que certaines populations d'espèces inscrites à l'Annexe I se sont reconstituées, par suite de mesures de conservation, et qu'elles ne sont plus menacées d'extinction. Elles peuvent être à même de supporter un niveau d'exploitation contrôlé et, il est vrai, peuvent même en profiter. C'est pourquoi, une procédure a été recommandée lors de la session CITES de New Delhi, Inde, en 1981, procédure par laquelle des populations d'espèces inscrites à l'Annexe I, qui pourraient profiter des effets de l'élevage en ranch, pourraient être transférées à l'Annexe II (Conf. 3.15). L'élevage en ranch est défini comme étant l'élevage dans un environnement contrôlé de spécimens prélevés à l'état sauvage, en vue de les commercialiser. Pour pouvoir être agrée, l'élevage doit être favorable à la population sauvage et ses produits doivent être marqués, afin qu'il soit possible de les distinguer des produits d'autres populations, de la même espèce, inscrites à l'Annexe $I$.

Il convient de noter que, étant donné qu'un échange continuel existe potentiellement entre les populations élevées en ranch et vivant à l'état sauvage dans le pays, elles sont traitées de façon identique aux yeux de la Convention et peuvent toutes deux faire l'objet d'un commerce. Il appartient à l'organe de gestion local d'élaborer les réglementations qui permettent de faire la différence entre les produits provenant d'animaux élevés en ranch et d'animaux sauvages. Cependant, une résolution adoptée en 1985 (Conf. 5.16) demande maintenant que toutes les conditions précisées dans la proposition originale d'élevage en ranch soient observées par toutes les Parties faisant commerce des spécimens de la population élevée en ranch. Ainsi, étant donné que la proposition australienne relative à l'élevage en ranch de $\underline{C}$. porosus stipule que la vente de peaux d'animaux qui n'ont pas été détenus dans un ranch pour au moins un an est interdite, les autres Parties ne devraient pas autoriser l'importation de telles peaux.

La population de $\underline{C}$. niloticus du zimbabwe a été transférée à 1'Annexe II, en 1983, sur la base d'un programme d'élevage en ranch et la population australienne de c. porosus l'a été, en 1985, sur la base d'un programme du même genre.

Une autre résolution a été adoptée à Buenos Aires, en 1985, au sujet du commerce des spécimens élevés en ranch. Elle recommande, entre autres, que les produits provenant d'élevages en ranch ne soient exportés ni vers des Etats non-Parties ni vers des Parties ayant formulé des réserves à l'égard des espèces faisant l'objet d'un élevage en ranch, et que les importations de ces produits en provenance de tels Etats ne soient pas acceptées. Certaines des ramifications de ce qui précède font que les exportations de peaux de c. 'porosus élevés en ranch ne devraient pas être autorisées par I'Australie si elles étaient destinées à singapour, qui n'est pas Partie, ou au Japon, qui a formulé une réserve à l'égard de cette espèce. 
La session de Buenos Aires, Argentine, fut remarquable, en ce sens que la procédure pour le transfert, de l'Annexe I à l'Annexe II, des espèces ayant été inscrites à l'Annexe I avant l'adoption des critères scientifiques prévus à cet effet et qui, de toute évidence, peuvent supporter un certain niveau d'exploitation, $y$ a été modifiée. Ia nouvelle procédure prévoit l'établissement d'un quota pour chaque pays souhaitant commercialiser ces espèces, dans le cadre d'un plan de gestion agréé. En vertu de cette procédure, la population de $\underline{c}$. porosus de l'Indonésie a été transférée à l'Annexe II avec un quota de

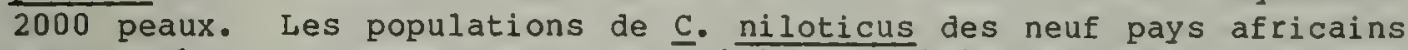
mentionnés au Tableau 2 ont aussi été transférées $\$ 1$ Annexe II avec les quotas indiqués.

Les programmes d'élevage en ranch ont de nombreux avantages par rapport à l'exploitation directe, car ils permettent des prélèvements plus importants dans une population sauvage donnée, ils produisent des peaux de meilleure qualité et, avec eux, il est plus facile de s'assurer que la réglementation est appliquée. Cependant, il est plus difficile de les mettre sur pied et ils exigent davantage de capitaux. Il paraît donc paradoxal que les décisions prises à Buenos Aires aient éliminé certains des avantages économiques des programmes d'élevage en ranch d'espèces inscrites à l'Annexe I - leurs marchés potentiels sont maintenant réduits - alors que le système de quotas pour le transfert de populations à l'Annexe II bénéficie d'une plus grande flexibilité en ce qui concerne la mise des produits sur le marché.

\section{METHODES}

L'enquête a été effectuée en 1983 et 1984. Le secrétariat CITES a envoyé une notification à toutes les Parties à la Convention au sujet de la nécessité d'enregistrer tous les établissements pratiquant l'élevage en captivité, à des fins comerciales, d'espèces inscrites à l'Annexe I. L'Unité de surveillance continue du cominerce de la faune et de la flore sauvages a pris contact également avec les autorités compétentes en matière de gestion de la faune sauvage des gouvernements des Etats non-Parties. Des contacts ont aussi été établis avec les membres du Groupe de spécialistes des crocodiles de la CSE, avec des associations d'éleveurs et avec d'autres personnalités connaissant le sujet. Chaque fois que possible, des questionnaires ont été envoyés aux fermes elles-mêmes en vue d'obtenir des informations détaillées sur leur cheptel, sur la reproduction, sur les captures à l'état sauvage, sur leur production commerciale et sur leurs techniques d'élevage. Les résultats présentés dans ce document sont tirés des réponses à ces requêtes, et aussi de matériels publiés et non publiés et de rapports de presse. Dans le répertoire, les résultats sont présentés pays par pays.

\section{RESULTATS ET DISCUSSION}

Les pays et les espèces mentionnés dans le texte sont énumérés au Tableau 3, lequel signale également l'emplacement des établissements. 
Les espèces les plus largement élevées dans les fermes sont $\underline{C}$. $\underline{\text { niloticus et }}$ c. porosus: ceci est, en partie, le reflet de leurr répartition étendue, mais aussi de la valeur de leurs peaux, puisque toutes deux sont hautement estimées par l'industrie du cuir.

Les effectifs des principales espèces détenus dans des fermes à vocation commerciale sont présentés au Tableau 4, où l'on peut voir qu'Alligator mississippiensis est problablement l'espèce la plus abondante, bien que $\underline{c}$. niloticus et $\underline{c}$. porosus atteignent des effectifs du même ordre de grandeur, les données sur ces espèces étant pourtant moins complètes. Le nombre total de fermes est indiqué au Tableau 5, ensemble avec d'autres renseignements relatifs à leur production. On pense qu'il existe d'autres fermes, par exemple à Singapour et en Malaisie, mais aucune information à leur sujet n'a pu être obtenue. Sur les 152 fermes connues, en 1985, moins de 20 existaient en 1974 et tout porte à croire que cette extension rapide se poursuit. Le cheptel en crocodiliens de 161'603's'accroît évidemment aussi. L'augmentation du cheptel du fait de la capture d'animaux sauvages et de la reproduction en captivité atteint environ $72 ' 000$ têtes par an.

Comme on peut s'y attendre pour une industrie aussi jeune, la production de peaux est relativement faible, les fermiers essayant apparemment de constituer leur cheptel. Avant 1979, alors que les fermes de Papouasie-Nouvelle-Guinée commençaient à produire, les seules quantités appréciables de peaux vendues par des fermes provenaient du zimbabwe. Cette enquête a montré qu'au moins 14'769 peaux de ferme avaient été mises sur le marché en 1983/84. Si l'on prend pour hypothèse que la plus grande partie de l'accroissement du cheptel des fermes est destiné à l'abattage dans un délai de quatre ans, la production pourrait atteindre 60.000 peaux vers 1989, bien qu'il soit peu probable que la croissance soit aussi rapide.

\section{Finances}

Bien que les contrôles exercés sur la chasse aux crocodiliens, en vertu de l'application des lois, jouent sous aucun doute un rôle important en créant des conditions favorables à l'établissement de fermes, le facteur qui, en fin de compte, déterminera leur avenir est leur succès financier.

Les compagnies commerciales, on peut le comprendre, rechignent à ouvrir leurs comptes pour permettre une étude et, ainsi, il est difficile d'évaluer leur rentabilité. De plus, la plupart des fermes se trouvent actuellement en phase de développement et l'on peut donc s'attendre à ce que leur bilan reste négatif tant qu'elles n'auront pas atteint leur pleine production. Pour commencer, il paraît donc raisonnable d'examiner de prime abord les fermes les plus anciennes.

L'une des fermes les plus anciennes du monde est celle de Samutprakan, en Thaillande. En 1983, on disait qu'elle disposait d'un cheptel de $30^{\prime} 000$ crocodiliens, mais elle n'a produit que 200 peaux. Financièrement, il est évident qu'elle ne pouvait survivre du produit de la seule vente des peaux, mais l'établissement tirait la majortié 
de ses revenus des touristes et elle prétendait s'autofinancer de cette façon.

Les fermes des Etats-Unis d'Amérique, elles aussi, présentent un mauvais rapport cheptel/production, bien qu'elles vendent aussi bien de la viande que des peaux, ce qui devrait contribuer à augmenter leurs bénéfices. Certaines fermes créent d'autres sources de revenu en vendant des animaux vivants à d'autres fermes et certaines comptent aussi sur les revenus produits par le tourisme. Une analyse récente (96) indique que la valeur d'un animal à l'abattage est de US\$ 200-300, alors que les frais de production, comprenant l'alimentation, le travail et l'acquisition de nouveau-nés, atteignent us\$\$85-110. Cela donne un bénéfice calculé de US\$ 80-192 par animal en tenant compte d'une mortalité de 10\%. A côté de cela, il y a les frais du capital investi, estimé entre US\$50.000 et US\$200'000 (40), dont les intérêts seraient de l'ordre de US\$ 5'000 à US\$20'000 par an pendant quatre ans avant l'entrée en production. Sur la base de l'estimation la plus pessimiste, un fermier devra donc vendre 345 animaux, pour payer ses intérêts, avant de commencer à récupérer son investissement initial.

L'augmentation du nombre de fermes, aux Etats-Unis d'Amérique, était lente jusqu'en 1982 et on a pensé que la principale raison poussant à l'élevage résidait dans l'intérêt porté aux alligators, lequel ne pouvait provenir que de personnes aisées et non intéressées à la réalisation de bénéfices rapides (123). Cependant, 1 'augmentation accélérée du nombre de fermes, ces deux dernières années, en Floride en particulier, donne à penser que des profits substantiels peuvent être espérés, s'ils n'ont encore été réalisés. Ceci peut être lié à l'augmentation du nombre de nouveau-nés, issus d'oeufs récoltés à l'état sauvage, disponibles et provenant du Louisiana Rockefeller Refuge et, tout particulièrement, du programme spécial de la Floride.

Les fermes du Zimbabwe bénéficient aussi d'un programme officiel de récolte d'oeufs et Magnusson (123) attribue leur rentabilité apparente au fait que la main d'oeuvre est bon marché et que l'approvisionnement en aliments protéiniques pour les crocodiles est peu coûteux et abondant, éléments qui pourraient tous deux, selon lui, se réduire à l'avenir. Plusieurs de ces fermes tirent aussi une part importante de leurs recettes du tourisme et de la vente de souvenirs (179).

En Papouasie-Nouvelle-Guinée, l'élevage en ranch des crocodiles constitue un modèle que d'autres pays tentent d'imiter et qui contribue à l'ensemble de la production mondiale de peaux provenant de fermes (Tableau 5). Bien que de nombreuses petites fermes installées initialement aient disparu, celles qui se maintiennent sont apparement capables de réaliser un bénéfice, presque exclusivement sur la vente des peaux (85). Une analyse de l'élevage en ranch en Australie, qui concerne aussi c. porosus, estimait les frais totaux d'acquisition et d'élevage par animal à $A \$ 35-55$ pour une taille à 1 'abattage de 5-6 ft $(1,52-1,83 \mathrm{~m})$. A ce stade, la valeur des peaux était évaluée à $A \$ 150-180$ (192). 
Il est évident que l'élevage en captivité des crocodiliens requiert davantage d'argent, tant en ce qui concerne les frais courants de garde du stock reproducteur que les capitaux nécessaires à la mise en place des installations de reproduction, que l'élevage à partir d'oeufs ou de jeunes prélevés à l'état sauvage. Magnusson (123) a mis en évidence le fait que la majorité des établissements qui ont obtenu des résultats financiers favorables dépendent des populations sauvages pour la plus grande partie de leur cheptel. Il est donc quelque peu surprenant que les fermes du zimbabwe et des Etats-unis d'Amérique fassent de plus en plus d'élevage à partir de leur propre cheptel et que la reproduction soit envisagée de plus en plus sérieusement en Papouasie-Nouvelle-Guinée. Ceci peut trouver une explication dans le fait que de nombreux établissements dépendent, en partie tout au moins, des recettes fournies par le tourisme. Une similarité existe véritablement entre ce qui est nécessaire pour satisfaire les touristes et ce qui l'est pour pratiquer la reproduction, soit des animaux adultes et de grande taille et des bassins semi-naturels; et les sommes importantes investies dans les nouvelles fermes orientées vers le tourisme montrent que les investisseurs espèrent, à tout le moins, gagner de l'argent en prenant ce genre de risque.

\section{L'élevage des crocodiliens et ses effets sur la conservation}

Le fait de savoir si l'élevage de crocodiliens est souhaitable du point de vue de la conservation a donné le jour à une controverse animée. Les arguments en faveur et contre l'élevage sont résumés comme suit:

\section{Diversion du commerce}

Etant donné qu'un marché existe pour les produits de crocodiliens et qu'il serait autrement approvisionné par la chasse exercée sur les populations sauvages, la mise à disposition des mêmes produits à partir d'animaux élevés dans des fermes pourrait satisfaire une partie de la demande et réduire la nécessité de chasser. La question de savoir si cela se passe ainsi dans la pratique ou de savoir si les produits des fermes $n^{\prime}$ augmentent pas simplement les dimensions du marché peut être discutée. L'effet principal devrait vraisemblablement être d'ordre économique: en réduisant le prix des peaux, on réduit les marges bénéficiaires fournies par la chasse à des niveaux inacceptables. Cet effet est particulièrement marqué là où la chasse est mal gérée et la population sauvage proche de l'extinction commerciale". Les peaux d'élevage tendent à être de meilleure et de plus uniforme qualité que les peaux sauvages, ce qui leur donne un avantage concurrentiel sur le marché, bien qu'elles puissent, de ce fait, se vendre à un prix plus élevé.

En contrepartie, on a émis $l^{\prime}$ hypothèse que si le commerce illicite a été réduit avec succès grâce aux mesures de contrôle, la demande de la part du public se réduira également. Toute nouvelle stimulation du marché du fait de l'introduction de produits de fermes augmentera la demande une fois de plus et renouvellera peut-être la pression, due à la chasse, s'exerçant sur les populations sauvages. Cet effet devrait probablement être plus grand là où le commerce a pratiquement cessé, 
soit en règle générale en ce quỉ concerne les espèces inscrites à l'Annexe I.

Les deux arguments sont influencés par l'importance relative des approvisionnements en peaux provenant des fermes et en peaux d'origine sauvage. Le commerce international des peux de crocodiliens a récemnent fait l'objet d'une étude par Hemley et Caldwell (94) qui ont trouvé que celui des principales espèces, à l'exception de Caiman crocodilus, ayant fait l'objet de rapports cITES atteignait au moins $82^{\prime} 000$ animaux par an, bien qu'ils attirent l'attention sur le fait qu'il s'agit certainement d'une sous-estimation. La production fermière de 12.000 peaux constitue déjà une part importante de ce marché et cette importance s'accroîtra. Cependant, la majeure partie du commerce concerne sans aucun doute $\underline{c}$. crocodilus, puisque les rapports CITES portent sur $700^{\circ} 000$ peaux par année et que le nombre réel est probablement supérieur au million (94). Taïwan est le seul territoire sur lequel cette espèce est élevée en grands nombres et cela surtout parce que la faible valeur commerciale des peaux signifie que l'élevage n'est économiquement rentable que si d'autres produits peuvent aussi être commercialisés. Il est donc peu probable que l'élevage produise un jour une part importante du marché mondial des peaux de $\underline{C}$. crocodilus, ou des peaux de crocodiliens dans leur ensemble, à moins que le commerce des peaux de caïmans sauvages ne soit drastiquement restreint.

\section{Contrôle du commerce}

Le contrôle du commerce illicite de produits d'espèces menacées d'extinction est compliqué par l'introduction sur le marché de produits fermiers acquis légalement. Ce problème a été abordé par les résolutions CITES sur l'élevage en captivité (Conf. 2.12.) et sur l'élevage en ranch (Conf. 3.15) qui recommandent le marquage approprié des produits, afin qu'ils puissent être distingués des produits provenant d'animaux prélevés à l'état sauvage. Cependant, on peut toujours craindre que des commerçants sans scrupules fassent usage de l'existence des fermes pour disposer de peaux sauvages illégalement acquises, soit directement à partir de la ferme, soit par le biais de réexportations à partir de pays tiers. Plusieurs pays ayant des élevages de crocodiliens ont élaboré des procédures en matière de permis et d'inspection dont le but est de prévenir ce genre d'activité, mais des allégations de "blanchissage" de peaux illicites ont certainement été formulées à l'égard de certaines fermes. Ce répertoire peut être utile pour contrer ce problème, puisqu'il tente de fournir le niveau réel des stocks actuels et de faire état des réussites effectivement obtenues en ce qui concerne la reproduction. Toute production de peaux dites fermières qui dépasse la capacité de production reconnue ou qui provient de pays qui n'ont pas la réputation de disposer de fermes devrait faire l'objet d'une enquête complémentaire.

\section{Effets sur les populations sauvages}

Si une espèce voit ses effectifs diminuer ou si elle devient menacée d'extinction à l'état sauvage, l'élevage en captivité peut avoir un effet protecteur pour une partie importante de la population. Si la reproduction peut aussi être assurée, la population 
peut être accrue jusqu'au point où il peut être possible de réintroduire des animaux reproduits en captivité dans la nature. Plusieurs établissements pratiquant la reproduction de crocodiliens sont sans aucun doute parvenus à ce stade, notamment avec les espèces Crocodylus moreletii, c. intermedius et Gavialis gangeticus, mais il s'agissait toujours d'établissements orientés vers la conservation et sans intentions commerciales. Le seul établissement commercial utilisant actuellement une espèce sérieusement menacée d'extinction, Crocodylus siamensis, est la ferme de samutprakan en Thaillande. La ferme des marais de zapata à Cuba pratique aussi la reproduction de Crocodylus rhombifer et de $c$. acutus, mais on ne sait pas à quel point cette ferme est concernée par le commerce. Cependant, il n'est-en aucune façon certain que les réintroductions d'animaux fermiers soient souhaitables, à cause de leur altération génétique due soit à une sélection artificielle soit à l'hybridation. La ferme de samutprakan et celle des marais de zapata possèdent déjà des cheptels substantiels d'animaux hybrides.

L'élevage en captivité est rarement totalement indépendant de la population sauvage et la capture d'animaux sauvages est souvent nécessaire, sinon pour les élever directement, du moins pour l'acquisiton du stock reproducteur. Ainsi, méme les établissements assurant la reproduction en captivité ont pour conséquence un drainage net, bien que réduit, sur les effectifs sauvages. Un élevage en ranch en plein développement prélève beaucoup plus d'animaux dans la nature, mais, même s'il n'est procédé à aucune réintroduction, l'une des principales conditions pour l'approbation d'un programme d'élevage en ranch au titre de la résolution conf. 3.15 est qu'il devrait, en contrepartie, profiter à la population sauvage, cela ne concernant toutefois que les espèces inscrites à l'Annexe I.

\section{Protection de l'habitat et des espèces}

Dans le passé, les crocodiliens étaient persécutés en tant que vermine et leur habitat marécageux est souvent détruit afin d'ouvrir la voie à une utilisation des sols "plus productive". La capacité des crocodiliens, qui a été démontrée, de créer un revenu peut aider à la promotion de la conservation de populations sauvages saines. Ceci s'applique en particulier à l'élevage en ranch, pour lequel l'ensemble de l'opération dépend du maintien d'un stock reproducteur sauvage; mais, dans une moindre mesure, les fermes pratiquant la reproduction artificielle peuvent encourager la conservation d'effectifs à l'état sauvage aux fins d'améliorations génétiques périodiques. Le maintien d'une population sauvage de crocodiliens est conditionné par la préservation de leur habitat, lequel est favorable à d'autres organismes du même milieu. Ainsi, l'attrait financier de l'exploitation des crocodiliens réduit aussi la pression économique qui s'exerce en faveur de l'assèchement des zones humides.

\section{Protection culturelle}

Les techniques d'élevage en ranch des crocodiliens peuvent être adaptées aux conditions d'une technologie villageoise permettant leur intégration dans la culture et l'économie des communautés rurales. Les programmes d'élevage en ranch de Papouasie-Nouvelle-Guinée et d'Australie septentrionale ont pour objectif déclaré de fournir des 
emplois aux indigènes. D'autres programmes visant à la réalisation d'un revenu entraînent fréquemment des effets technologiques largement plus importants et provoquent une dislocation sur le plan social.

\section{Mélange génétique et risque de maladie}

Les autres inconvénients potentiels comprennent l'introduction accidentelle d'espèces non indigènes ou de races génétiquement distinctes parmi la population sauvage, parce que des animaux se sont échappés de la ferme, ainsi que la dissémination de maladies.

\section{PERSPECTIVES D'AVENIR}

Dans la plupart des pays qui arbritent des élevages de crocodiliens, il apparaît qu'ils augmentent en nombre et en nombre d'animaux, et que la production de peaux s'accroît. Les problèmes techniques posés par l'élevage ont été surmontés, dans une large mesure, mais quant à savoir si cette croissance se poursuivra ou si cette industrie disparaîtra, cela dépendra de sa rentabilité à long terme. Le rapport entre le nombre d'animaux prélevés à l'état sauvage ("élevage en ranch") et le nombre d'animaux reproduits en captivité constitue un facteur important du point de vue de la conservation. Le nombre total d'animaux reproduits dans des fermes semble s'accroitre et pourrait représenter quelques $40 \%$ du nombre total d'animaux s'ajoutant chaque année au cheptel de ces fermes. A première vue, cela paraît encourageant, mais mérite un examen plus approfondi.

La reproduction en captivité a joué un rôle important pour la conservation de plusieurs espèces de crocodiliens sérieusement réduites en nombre, mais il s'agissait le plus souvent d'opérations non commerciales. L'élevage en captivité à des fins commerciales, ainsi qu'on l'a vu plus haut, fait moins en faveur de la conservation et ne devrait pas être considéré, comne il l'est souvent, comme une alternative à la conservation des habitats. L'élevage en ranch, par contre, peut être beaucoup plus favorable, car il requiert le maintien d'une population sauvage saine et de l'habitat qui l'abrite (123). Dans le fond, il diffère peu d'une exploitation contrôlée des grands animaux pour leurs peaux; aux Etats-Unis d'Amérique et en Papouasie-Nouvelle-Guinée, les deux types d'exploitation sont conduits côte à côte. L'élevage en ranch présente certains avantages sur la récolte directe car il paraît plus facile de le régulariser, en particulier si, comme au Zimbabwe, aux Etats-Unis d'Amérique et en Australie, la récolte des oeufs est entièrement effectuée par le personnel gouvernemental ou sous son étroit contrôle. Le maintien d'un cheptel élevé en ranch séparé donnerait aussi une assurance, jusqu'à un certain point, au cas où un désastre se produirait dans le milieu naturel ou si le contrôle effectif de la récolte était rompu en raison, par exemple, d'une instabilité politique.

C'est pourquoi, la cause de la conservation des crocodiliens pourrait être mieux servie par la mise en place de plans efficaces de gestion des populations sauvages, lesquels comprendraient l'élevage en ranch, la récolte directe ou une combinaison des deux, que par un arrêt total de l'exploitation à l'état sauvage et le développement de 


\section{Introduction}

l'élevage en captivité. Le succès de tout plan de gestion de ce type dépend entièrement d'une recherche de base minutieuse permettant de déterminer les niveaux des populations existantes et de l'aptitude à conduire l'exploitation de façon contrôlée. Le niveau élevé du commerce illicite de produits de crocodiliens (94) donne à penser que le degré actuel de contrôle est loin d'être adéquat dans de nombreuses parties du globe.

\section{REMERCIEMENTS}

La réalisation de cette enquête aurait été totalement impossible sans l'aide et la coopération accordées par les très nombreux correspondants qui ont répondu à nos lettres et rempli les questionnaires. Leur aide a été mentionnée chaque fois que possible dans les références, mais les auteurs souhaitent leur exprimer leur gratitude ici-même. Les fonds nécessaires à la réalisation de cette enquête ont été généreusement fournis par l'International Fur Trade Federation et par I'UICN. 
Los cocodrilos se explotan en forma intensiva para la comercialización de sus pieles las cuales alcanzan precios muy elevados. Hasta hace poco tiempo, la demanda de pieles se basaba exclusivamente en la caza de las poblaciones silvestres, pero en los últimos años se ha notado un gran incremento de criaderos de cocodrilos. Los primeros de ellos, denominados "granjas", estaban destinados, sin ningún lugar a dudas, al público en general, más bien en el sentido de zoológicos, y muchos de ellos aun conservan ese caracter. Sin embargo, la cría para la producción comercial de pieles se practica cada vez más. Algunas granjas venden también carne de cocodrilo $y$, en Taiwan, este fin provee algunas veces la fuente principal de ingresos.

La razón de este aumento de popularidad de la cría de cocodrilos es dificil de evaluar, pero tiene que ver ciertamente con la reducción registrada en el aprovisionamiento de pieles silvestres. Este aumento se debe en parte, a la declinación de las poblaciones silvestres debido a la caza excesiva, a la persecución y a la destrucción del habitat, pero el control relativo a la aplicación de las leyes podría tener una importancia aun mayor. La principal de ellas es la Convención sobre el Comercio Internacional de Especies Amenazadas de Fauna y Flora Silvestres (CITES). La mayoría de los cocodrilos están incluidos en el Apéndice I de la Convención (ver Cuadro I), lo que significa que todas las transacciones comerciales entre los países Partes están prohibidas a menos que los especímenes provengan de poblaciones criadas en cautividad. Desde la entrada en vigor de la Convención, en 1975, la eficacia de los controles comerciales ha aumentado, debido a que un mayor número de países son ahora partes de la Convención y también a que se ha registrado una mejora en los procedimientos de aplicación. La demanda de pieles "clásicas" de cocodrilos más solicitadas, especialmente las de Crocodylus niloticus y Crocodylus porosus, se mantiene a un nivel alto $y$, como las otras fuentes de pieles se han cerrado, las operaciones de cría en granjas parecen haber prosperado.

Esta Guía de criaderos de cocodrilos fue elaborada, en parte, para facilitar la aplicación de los controles CITES, identificando los criaderos y las denominadas "granjas" que no realizan la reproducción de cocodrilos, y también para determinar la importancia del criadero, con miras a evaluar sus efectos sobre la conservación de los cocodrilos. También trata de establecer una lista de todas las granjas comerciales de cocodrilos $y$ ofrece informaciones detalladas de sus stocks, producción, logros en materia de reproducción así como sobre las técnicas de cría. La encuesta fue elaborada, en primer lugar, con el objeto de localizar los criaderos comerciales, pero también se han incluido a los grandes centros de reproducción de cocodrilos orientados hacia la conservación, en parte porque algunos de ellos podrían transformarse en futuros criaderos comerciales. Por esa misma razón, se tuvieron también en cuenta los proyectos de criaderos comerciales. En la presente Guía, la palabra "granja" se utiliza para designar cualquier criadero en cautividad, en el sentido más amplio del término (es decir también la detención durante por 10 menos un 
cierto periodo), comprende entonces a los criaderos cuyo plantel fue obtenido de la naturaleza $y$ a los criaderos que practican la reproducción en cautividad. Los zoológicos del mundo entero poseen cocodrilos que se reproducen, pero no se los ha tomado en consideración.

Cabe señalar que la inclusión de un criadero en la presente Guía no implica de ninguna forma que la granja satisfaga las exigencias de cITES relativas a su reconocimiento como cría en cautividad. Esa función la realiza la secretaría CITES por medio del Registro de establecimientos que practican la cría en cautividad, según la explicación ofrecida en la sección siguiente.

\section{Controles CITES del comercio}

Debido a que los controles CITES son muy importantes para comprender la cría de cocodrilos y a la confusión que reina al respecto de su interpretación, la siguiente sección resume las exigencias relativas al comercio de productos de cocodrilos.

Todo el comercio concerniente a los países Partes de la Convención se halla sometido a las disposiciones de ella, siempre que no se trate de especímenes adquiridos antes de que la convención haya entrado en vigor o a menos de que el país haya formulado una reserva con respecto a la especie en cuestión, en ese caso, ese país es considerado como un Estado no Parte. Los países que formularon reservas con respecto a los cocodrilos se mencionan en el Cuadro I. Otros países, como por ejemplo Italia y Francia, habían formulado reservas, pero actualmente las han retirado.

Todos los cocodrilos gozan de protección de acuerdo con la Convención ya que se hallan incluidos en el Apéndice $I$ en el Apéndice II.

En el Apéndice I se hallan incluidos los taxa amenazados de extinción que están o podrían estar amenazados por el comercio. En la práctica, el comercio internacional de esas especies se halla prohibido, siempre que la Parte exportadora no emita un permiso de exportación. Esto solamente puede hacerse si el comercio no perjudica a la supervivencia de la población silvestre y si la Parte importadora emitió un permiso declarando que los animales o los productos no serán utilizados con fines primordialmente comerciales. Existen algunas excepciones, la principal concierne al comercio de animales que provienen de poblaciones criadas en cautividad de acuerdo con las condiciones indicadas más abajo. Esos animales son tratados como si estuvieran incluidos en el Apéndice II.

En el Apéndice II están incluidos los taxa cuyo comercio debe estar sometido a una reglamentación estricta con el objetivo de evitar que ellos, o las especies similares incluidas en ese mismo Apéndice, no esten amenazadas de extinción en el futuro. Por lo tanto, el comercio está solamente permitido cuando el país de exportación emite un permiso de exportación que indica que el comercio no perjudica a la supervivencia de la población silvestre. 
Los países Partes de la Convención deben tratar a los Estados no partes casi como si estos fueran Partes. En otros términos, si un comerciante de un Estado Parte desea importar una especie del Apéndice II de un Estado no Parte debe obtener un documento equivalente al permiso de exportación CITES.

\section{Cría en cautividad}

En la reunión CITES de San José, Costa Rica, 1979, se definieron las condiciones por las cuales los especímenes de una especie incluida en el Apéndice I pueden ser consideracios como "criados en cautividad", las cuales se especifican en la resolución cITEs conf. 2.12. Resumiendo, esas condiciones son las siguientes:

1. Los animales pueden solamente ser comercializados como especímenes criados en cautividad si nacieron en cautividad $y$ si descienden de padres que se reprodujeron en cautividad (o en un "medio controlado").

2. El stock parental debe ser (i) obtenido sin perjudicar la supervivencia de la especie al estado silvestre, (ii) mantenido sin incrementos provenientes de las poblaciones silvestres, excepto aquellos aportes ocasionales con fines de mejoramiento genético, (iii) administrados de forma que se pueda ofrecer la prueba de que ese stock permite producir en forma segura una descendencia de segunda generación.

Conviene señalar que las granjas no necesitan producir descendencia de segunda generación siempre que las técnicas que se aplican hayan ofrecido la prueba, en otro sitio, de que se puede producir ese tipo de descendencia.

\section{Registro de establecimientos que realizan cría en cautividad}

Algunos comerciantes poco escrupulosos pueden abusar de esas reglamentaciones simplemente obteniendo animales del medio silvestre $y$ vendiéndolos pretendiendo de que fueron criados en cautividac. Por 10 tanto es necesario establecer un registro efectivo de los criaderos reconocidos que producen especímenes de especies del Apéndice I criados en cautividad. Esta necesidad fue reconocida en la reunión de CITES de Gaborone, Botswana, en 1983, donde se adoptó una resolución (Conf. 4.15) que recomienda que las transacciones comerciales relativas a especies del Apéndice I criadas en cautividad esten solamente autorizadas para los establecimientos registrados por la Secretaría CITES. El registro se hace efectivo cuando la Autoridad Administrativa CITES del país de origen comunicó a la secretaría información detallada con respecto a la granja (información que se especifica en la notificación a las Partes No. 223 del 13 de octubre de 1983) y cuando confirmó que se respetan las condiciones especificadas en la resolución conf. 2.12. Al momento de la impresión de esta Guía, sólo se habían registrado cuatro establecimientos que crían cocodrilos incluidos en el Apéndice I, uno en Madagascar, uno en Queensland, Australia, uno en Tailandia y el fltimo en Transvaal, Sudáfrica. 


\section{Cría en granjas}

Se ha reconocido que algunas poblaciones de especies incluidas en el Apéndice I se han reconstituido debido a las medidas de conservación, por lo que ya no se encuentran más amenazadas. Estas poblaciones pueden soportar un nivel de explotación controlado y pueden por lo tanto beneficiarse de ello. Por tal motivo, se recomendó un procedimiento en la reunión de CITES de Nueva Delhi, India, 1981, por el cual algunas poblaciones de especies incluidas en el Apéndice I que podían gozar de los efectos de la cría en granjas podían ser transferidas al Apéndice II (Conf. 3.15). La cría en granjas se define como la cría en un medio ambiente controlado, de especímenes obtenidos de la naturaleza, con miras a su comercialización. Para que sea reconocido, el criadero debe favorecer a la población silvestre y sus productos deben ser marcados para que puedan ser diferenciados de los otros productos provenientes de otras poblaciones de la misma especie incluidas en el Apéndice I.

Conviene señalar que, dado que existe un intercambio potencial continuo entre las poblaciones criadas en granjas y aquellas que viven al estado silvestre en el país, se las trata en forma similar desde el punto de vista de la Convención y ambas pueden ser objeto de comercio. Corresponde a la Autoridad Administrativa local elaborar las reglamentaciones que permitan diferenciar los productos provenientes de animales criados en granjas de aquellos provenientes del medio natural. Sin embargo, en 1985 se adoptó una resolución (Conf. 5.16) que solicita que todas las condiciones establecidas en la propuesta original de cría en granjas sean respetadas por todas las partes que realizan comercio de especímenes de la población criada en granjas. De esta forma $y$ dado que la propuesta australiana relativa a la cría en granjas de $C$. porosus estipula la prohibición de vender pieles de animales que no se encuentran en una granja desde hace por lo menos un año, las otras partes no deberían autorizar la importaciones de dichas pieles.

La población de c. niloticus de zimbabwe fue transferida al Apéndice II en 1983 sobre la base de un programa de cría en granjas y la población australiana de C. porosus fue transferida en 1985 sobre la base de un programa del mismo tipo.

En 1985, en Buenos Aires se adoptó otra resolución con respecto al comercio de especímenes criados en granjas. La misma recomienda, entre otras cosas, que los productos provenientes de cría en granjas no se exporten hacia Estados no Partes ni hacia Partes que hayan formulado reservas con respecto a las especies que son objeto de una cría en granjas, y que no se acepten las.importaciones de productos provenientes de esos Estados. Algunas connotaciones de lo que precede hacen que Australia no debería autorizar las exportaciones de pieles de $C$. porosus criados en granjas si su destino es singapur, que no es Parte, o Japón que ha formulado una reserva con respecto a esa especie.

La reunión de Buenos Aires, Argentina, fue notable en el sentido de que se modificó el procedimiento para transferir del Apéndice I al Apéndice II, de las especies que fueron incluidas en el Apéndice I 
antes de la adopción de los criterios cientŕficos a tal efecto y que evidentemente pueden soportar un cierto nivel de explotación. El nuevo procedimiento preve el establecimiento de un cupo para cada país que desea comercializar esas especies, dentro del marco de un plan de manejo reconocido. Por medio de este procedimiento, la población de $\mathrm{C}$. porosus de Indonesia fue transferida al Apéndice II con un cupo de 2000 pieles. Las poblaciones de C. niloticus de los nueve países africanos mencionados en el cuadro 2 también fueron transferidas al Apéndice II con los cupos indicados.

Los programas de cría en granjas poseen numerosas ventajas con respecto a la explotación directa, ya que permiten capturas más importantes de una determinada población silvestre, producen pieles de mejor calidad $y$, con ellos, es más fácil asegurarse que se aplica la reglamentación. Sin embargo, es más difícil aplicarlos y necesitan capitales más importantes. En consecuencia parece paradojico que las decisiones tomadas en Buenos Aires hayan eliminado ciertas ventajas económicas de los programas de cría en granjas de especies incluidas en el Apéndice I - sus mercados potenciales son actualmente menores mientras que el sistema de cupos para la transferencia de poblaciones al Apéndice II goza de una mayor flexibilidad en 10 que respecta a la disponibilidad de los productos en el mercado.

\section{METODOS}

La encuesta fue efectuada en 1983 y 1984. La Secretaría CITES envió una notificación a las partes de la Convención con respecto a la necesidad de registrar todos los establecimientos que realizan la cría en cautividad con fines comerciales de especies incluidas en el Apéndice I. La Unidad de Vigilancia continua del Comercio de Fauna y Flora Silvestre también tomó contacto con las autoridades competentes en materia de manejo de fauna silvestre de los gobiernos de los Estados no Partes. También se establecieron contactos con los miembros del Grupo de Especialistas de Cocodrilos de la CSE, con las asociaciones de criadores y con otras personalidades que conocen el tema. Siempre que fue posible, se enviaron cuestionarios a las granjas mismas con el objeto de obtener información detallada sobre sus stocks, la reproducción, la captura al estado silvestre, su producción comercial y sus técnicas de cría. Los resultados presentados en este documento provienen de las respuestas a esas encuestas, y también de materiales publicados $y$ no publicados $y$ de informes de prensa. En la Guía, los resultados se presentan por país.

\section{RESULTADOS Y DISCUSION}

Los países y las especies mencionadas en el texto se enumeran en el Cuadro 3, el cual indica también donde se encuentran los establecimientos. Las especies más intensivamente criadas en granjas son C. niloticus y c. porosus: estoes, en parte, el reflejo de su amplia distribución, pero además el valor de sus pieles, ya que ambas son muy estimadas por la industria del cuero. 
Los efectivos de las principales especies que se encuentran en las granjas de tipo comercial se presentan en el Cuadro 4, donde se puede ver que el Alligator mississippiensis es probablemente la especie más abundante, aunque C. niloticus y C. porosus alcanzan efectivos del mismo orden de tamaño, los datos sobre esas especies son sin embargo bastante incompletos. El numero total de granjas se indica en el Cuadro 5, junto a otras informaciones relativas a su producción. Se cree que existen otras formas, por ejemplo en Singapur y en Malasia, pero no se ha podido obtener ninguna otra información. De las 152 granjas conocidas en 1985, menos de 20 existían en 1974 y todo indica que esa rápida expansión continua. El plantel de cocodrilos de 161.603 evidentemente también aumenta. El aumento del plantel debido a la captura de animales silvestres y a la reproducción en cautividad alcanza aproximadamente 72.000 cabezas por año.

Como es de esperar con una industria tan jóven, la producción de pieles es relativamente baja, los criadores tratan aparentemente de constituir sus planteles. Antes de 1979, mientras las granjas de Papua Nueva Guinea comenzaban a producir, las únicas cantidades apreciables de pieles vendidas por las granjas provenían de zimbabwe. Esta encuesta demostró que por 10 menos 14.769 pieles de granja habían entrado en el mercado en 1983/84. Si se considera la hipótesis de que la mayor parte del aumento del plantel de granjas está destinado a la matanza en un plazo de cuatro años, la producción podrían alcanzar 60.000 pieles hacia 1989, aunque es poco probable que el aumento sea tan rápido.

\section{Finanzas}

Aunque los controles ejercidos, sobre la caza de cocodrilos en virtud de la aplicación de las leyes juega sin ninguna duda un papel muy importante creando condiciones favorables al establecimiento de granjas, el factor que, en fin de cuentas, determinará su futuro es el éxito financiero.

Las compañías comerciales, se lo puede comprender, no están muy dispuestas a mostrar sus cuentas para permitir un estudio $\mathrm{y}$, de esta forma, es dificil evaluar su rentabilidad. Además, la mayoría de las granjas se encuentran actualmente en una etapa de desarrollo y por lo tanto se puede esperar que el balance sea negativo hasta que no se alcance la plena producción. Para comenzar, parece entonces razonable examinar primeramente las granjas más antiguas.

Una de las granjas más antiguas del mundo es la de Samutprakan en Tailandia. En 1983, se decía de que disponía de un plantel de 30.000 cocodrilos, pero solamente produjo 200 pieles. Financieramente es evidente que ella no podía solamente sobrevivir del producto de la venta de pieles, el establecimiento obtenía la mayor parte de sus ingresos de los turistas y pretendía autofinanciarse de esa forma.

También las granjas de los Estados Unidos, presentaban una mala relación plantel/producción, aunque ellas venden también carne y pieles, 10 que debería contribuir a aumentar sus beneficios. Algunas granjas crean otras fuentes de ingresos vendiendo animales vivos a 
otras granjas y algunas cuentan también con los ingresos producidos por el turismo. Un análisis reciente (96) indica que el valor de un animal en el matadero es de US\$200-300, mientras que los gastos de producción, que comprenden la alimentación, el trabajo y la adquisición de recién nacidos, alcanzan us\$85-100. Esto ofrece un beneficio estimado de US\$80-192 por animal tomando en cuenta una mortalidad del 108. Ante ésto el costo del capital invertido, estimado a ser US\$50.000-200.000 (40), cuyo interés tenaría un valor de US\$5000-20.000 al año por cuatro años antes de que ninguna producción tomara lugar. Con las estimaciónes más pesimistas, un granjero necesitaría pues vender 345 animales sclamente para pagar el interés autres de recuperar su inversión inicial.

El aumento del número de granjas en los Estados Unidos de América fue lento hasta 1982 y se creyó que la causa principal en favor de los criaderos residía en el interés que existía con respecto a los aligatores, el cual podía solamente provenir de personas ricas y no interesadas en la obtención de beneficios rápidos (123). Sin embargo, el aumento acelerado del número de granjas durante estos dos últimos años, especialmente en Florida, hace pensar que se pueden esperar ganancias substanciales, si es que ya no se han obtenido. Esto puede estar ligado al aumento del número de recién nacidos, eclosionados de huevos recogidos en la naturaleza, disponibles y provenientes del Louisiana Rockefeller Refuge $y$ especialmente del programa especial de Florida.

Las granjas de zimbabwe gozan también de un programa oficial de recolección de huevos $y$ Magnusson (123) atribuye su aparente rentabilidad al hecho de que la mano de obra es barata $y$ a que el aprovisionamiento en alimentos ricos en proteinas para los cocodrilos es poco costoso y abundante, ambos elementos podrían, según ese autor, disminuir en el futuro. Varias de esas granjas también obtienen una parte importante de sus ingresos del turismo $y$ de la venta de recuerdos para el turista (179).

La cría en granjas de cocodrilos en Papua Nueva Guinea constituye un modelo que otros países tratan de imitar $y$ que contribuye al conjunto de la producción mundial de pieles provenientes de granjas (Cuadro 5). Aunque numerosas pequeñas granjas inicialmente instaladas ya han desaparecido, las que se mantienen son aparentemente capaces de realizar un beneficio, casi exclusivamente sobre la venta de pieles (85). Un análisis de la cría en granjas en Australia, que concierne también C. porosus, estimaba los gastos totales de adquisición y de cría por animal a $\$ \$ 35-55$ para un tamaño de matadero de 5-6 piés $(1,52-1,83 \mathrm{~m})$. A este nivel, el valor de las pieles estaba evaluado a A $\$ 150-180$ (192).

Es evidente que la cría en cautividad de cocodrilos requiere más dinero, en lo que respecta a los gastos corrientes y de conservación del stock reproductor, que el capital inicial necesario al establecimiento de las instalaciones de reproducción, que la cría a partir de huevos 0 de juveniles obtenidos al estado silvestre. Magnusson (123) ha indicado que la mayoría de lcs establecimientos que logran un éxito financiero son aquellos cuyos stocks de crianza 
dependen en su mayor parte de las poblaciones silvestres de cocodrilos. Por lo tanto, es un poco soprendente que las granjas de zimbabwe $y$ de los Estados Unidos de Améxica realizan cada vez más crías a partir de sus propios planteles y la reproducción es tratada cada vez más seriamente en Papua Nueva Guinea. Esto puede explicarse por el hecho de que numerosos establecimientos dependen, por lo menos en parte, de los ingresos provenientes del turismo. Existe una verdadera semejanza entre lo requerido para satisfacer a los turistas y 10 requerido para practicar la reproducción, es decir animales adultos $y$ de gran tamaño y piletones seminaturales, y los importantes capitales invertidos en las nuevas granjas orientadas hacia el turismo demuestran que los financistas esperan, finalmente, ganar dinero al hacerse cargo de ese tipo de riesgo.

\section{La cría de cocodrilos y sus efectos sobre la conservación}

El hecho de saber si la cría de cocodrilos es deseable desde el punto de vista de la conservación originó una animada controversia. los argumentos en favor $y$ en contra de la cría se resumen a continuación:

\section{Desviación del comercio}

Dado que existe un mercado para los productos de cocodrilos que de otra forma sería aprovisionado por la caza de las poblaciones silvestres, disponer de esos mismos productos a partir de animales criados en granjas podría satisfacer una parte de la demanda y reducir la necesidad de caza. Puede discutirse la cuestión de saber si eso ocurre en la práctica o si los productos de las granjas aumentan simplemente la amplitud del mercado. Normalmente, el efecto principal debería ser de orden económico, disminuyendo el precio de las pieles o reduciendo a niveles inaceptables el margen de ganancia ofrecido por la caza. Este efecto es particularmente notable cuando la operación de caza es manejada pobremente y la población silvestre se aproxima hacia la "extincción comercial". Las pieles de criadero tienden a ser de mejores $y$ de calidad más uniforme que las pieles silvestres, lo que le ofrece una ventaja competitiva en el mercado, aunque puedan, por eso mismo, venderse a un precio más elevado.

Por otro lado se ha emitido la hipótesîs de que si el comercio ilegal se pudo reducir con éxito gracias a medidas de control, la demanda del público también disminuirá. Cualquier nueva estimulación del mercado debido a la introducción de productos de granja aumentará la demanda aun más y renovará quizás la presión de caza sobre las poblaciones silvestres. Este efecto debería también ser más importante en los sitios donde el comercio ha practicamente cesado, en general para las especies incluidas en el Apéndice I.

Ambos argumentos están influenciados por la importancia relativa de los aprovisionamientos en pieles provenientes de granjas $y$ del medio silvestre. Recientemente el comercio internacional de pieles de cocodrilos ha sido estudiado por Hemley y Caldwell (94) que encontraron que el comercio de las principales especies, excepto Caiman crocodilus, mencionados en los informes CITES alcanzaron por lo menos 82.000 animales por año, aunque señalan que se trata ciertamente 
de una subestimación. La producción en granjas de 12.000 pieles ya constituye una parte importante de ese mercado y esta importación irá en aumento. Sin embargo, la mayor parte del comercio concierne sin ninguna duda a $c$. crocodilus, ya que los informes CITES indican 700.000 pieles por año $y$ que el número real es probablemente superior al millón (94). Taiwan es el único territorio en el cual esta especie es criada en gran cantidad, principalmente porque el bajo valor comercial de las pieles significa que el criadero es económicamente rentable solamente si se pueden comercializar otros productos. En consecuencia, es poco probable que la cría produzca alguna vez una parte importante del mercado mundial de pieles de C. crocodilus, o de pieles de cocodrilos en su conjunto, a menos que el comercio de pieles de caimanes silvestres disminuya en forma drástica.

\section{Control del comercio}

El control del comercio ilegal de productos de especies amenazadas de extinción se complica por la introducción en el mercado de productos de granja adquiridos legalmente. Este problema fue tratado por las resoluciones CITES sobre la cría en cautividad (Conf. 2.12) y sobre la cría en granjas (Conf. 3.15) que recomiendan el marcado apropiado de los productos, con el objeto de que puedan ser distinguidos de los productos provenientes de animales obtenidos de la naturaleza. Sin embargo, siempre se teme que algunos comerciantes sin escrúpulos utilicen a las granjas para disponer de pieles silvestres adquiridas en forma ilegal, ya sea en forma directa a partir de la granja, o por medio de reexportaciones a partir de otros países. Varios países que poseen criaderos de cocodrilos elaboraron procedimientos en materia de permisos y de inspección cuyo objetivo es prevenir ese tipo de actividad, pero se han señalado operaciones de "blanqueo" de pieles ilegales realizadas por algunas granjas. La presente Guía puede ser útil para evitar ese problema ya que se trata de ofrecer un nivel real de los stocks actuales $y$ de informar sobre los éxitos efectivos obtenidos con respecto a la reproducción. Cualquier producción de pieles provenientes de granjas que sobrepase la capacidad de producción reconocida o que provengan de países que no disponen de granjas deberían ser investigados.

\section{Efecto sobre las poblaciones silvestres}

Si los efectivos de una especie disminuyen 0 si se encuentran amenazados de extinción al estado silvestre, la cría en cautividad puede tener un efecto de protección para una parte importante de la población. Si la reproducción puede también asegurarse, la población puede aumentar hasta un punto en que puede ser posible la reintrođucción de animales reproducidos en cautividad en la naturaleza. Varios establecimientos que practican la reproducción de cocodrilos han logrado sin lugar a dudas alcanzar ese nivel, especialmente con las especies Crocodylus moreletii, $\frac{\text { Crocodylus }}{\text { intermedius y Gavialis gangeticus, pero siempre se }}$ intermedius y Gavialis gangeticus, pero siempre se trató de establecimientos orientados hacia la conservación y sin intenciones
comerciales. El unico establecimiento comercial que utiliza actualmente una especie seriamente amenazada de extinción, crocodylus siamensis, es la granja de Samutprakan en Tailandia. La granja de los 
pantanos de zapata en Cuba practica también la reproducción de Crocodylus rhombifer y Crocodylus acutus, pero no se conoce el nivel en que esta granja esta concernida por el comercio. Sin embargo, no se ha podido determinar si es de desear la reintroducción de animales provenientes de granjas, a causa de su alteración genética debido a la selección artificial o a la hibridación. La granja de Samutprakan y la de los pantanos de zapata ya poseen importantes planteles substanciales de animales híbridos.

Muy raramente la cría en cautividad es totalmente independiente de la población silvestre $y$ a menudo es necesario la captura de animales silvestres, si no es para criarlos directamente por lo menos para adquirir un stock reproductor. De esta forma, mismo los establecimientos que aseguran la reproducción en cautividad tienen en consecuencia un drenado neto, aunque reducido, de los efectivos silvestres. Una cría en granjas en pleno desarrollo captura muchos más animales de la naturaleza, pero, aunque no realice ninguna reintroducción, una de las condiciones principales para la aprobación de un programa de cría en granjas de acuerdo con la resolución conf. 3.15 es que debería, como contrapartida, beneficiar a la población silvestre, esto concierne solamente a las especies incluidas en el Apéndice I.

\section{Protección del habitat y de las especies}

En el pasado, los cocodrilos eran perseguidos como animales perjudiciales $y$ a menudo sus habitats pantanosos se destruyen con el objeto de abrir una vía a una utilización del suelo "más productiva". La capacidad de los cocodrilos de producir fuentes de ingresos, que ya se ha demostrado, puede ayudar a promover la conservación de poblaciones silvestres sanas. Esto se aplica en particular a la cría en granjas, para la cual el conjunto de la operación depende del mantenimiento de un stock reproductor silvestre pero, en mucha menor medida, las granjas que practican la reproducción artificial pueden alentar la conservación de efectivos al estado silvestre con el objeto de periódicas mejoras genéticas. El mantenimiento de una población silvestre de cocodrilos se halla condicionado por la preservación de su habitat, el cual es favorable a los otros organismos que viven en el mismo medio. En consecuencia, la atracción financiera de la explotación de cocodrilos ređuce también la presión económica que se ejerce en favor del secado de las zonas húmedas.

\section{Protección cultural}

Las técnicas de cría de cocodrilos en granjas pueden ser adaptadas a las condiciones de una tecnología de pueblo para permitir la integración de la cultura y de la economía de las comunidades rurales. Los programas de cría en granja de Papua Nueva Guinea y de Australia septentrional declaran como objetivo el ofrecimiento de empleos a los indígenas. Frecuentemente, otros programas que tienden a obtener un ingreso provocan problemas a nivel social. 


\section{Mezcla genética y riesgos de enfermedades}

Los otros inconvenientes potenciales comprenden la introducción accidental de especies no indígenas $\circ$ de razas genéticamente diferentes en la población silvestre, porque algunos animales se escaparon de la granja, así como la diseminación de enfermedades, propias a las granjas, a las poblaciones silvestres.

\section{PERSPECTIVAS FUTURAS}

En la mayoría de los países que realizan operaciones de cría en granjas de cocodrilos parece que estos establecimientos aumentan en número así como en cantidad de animales y que la producción de pieles aumenta. Los problemas técnicos originados de la cría han sido, en gran medida, solucionados, pero saber si este crecimiento continuará o si esta industria desaparecerá depende de su rentabilidad a largo plazo. El numero de animales silvestres capturados en la naturaleza ("cría en granjas") y el número de animales reproducidos en cautividad constituye un factor importante desde el punto de vista de la conservación. El número total de animales reproducidos en las granjas parece aumentar y podría representar el 408 del número total de animales que se agregan anualmente al plantel de esas granjas. A primera vista, esto parece alentador, pero merece un examen más profundo.

La reproducción en cautividad tuvo un importante papel en la conservación de varias especies de cocodrilos seriamente reducidas en número, pero se trataba a menudo de operaciones no comerciales. La cría en cautividad con fines comerciales, tal como se lo explica más arriba, no es tan beneficiosa para la conservación, y por lo tanto no debería ser vista, como frequentemente es, como una alternativa a la conservación del habitat. En cambio, la cría en granjas, puede ser mucho más beneficiosa ya que requiere el mantenimiento de una población silvestre sana así como del habitat que la alberga (123) En esencia, difiere poco de una explotación controlada de pieles de grandes animales, en los Estados Unidos de América y en Papua Nueva Guinea, los dos tipos de explotación se llevan paralelamente. La cría en granjas presenta ciertas ventajas sobre la recolección directa ya que parece más fácil reglamentar, especialmente si, como en zimbabwe, Estados Unidos de América y en Australia, la recolección de huevos es totalmente efectuada por personal del gobierno $\circ$ bajo su estricto control. El mantenimiento por separado de un plantel en granjas ofrece también cierta garantía, en el caso de que hubiera un desastre en el medio natural o en el caso de que se interrumpiera el control efectivo de la recolección debido por ejemplo a la inestabilidad política.

Por tal motivo, la causa de la conservación de cocodrilos estaría mejor servida si se estableciera un plan de manejo eficaz de las poblaciones silvestres, el cual comprendería la cría en granjas, la recolección directa o una combinación de ambas, en lugar del paro total de la explotación al estado silvestre y el desarrollo de la cría en cautividad. El éxito de cualquier plan de manejo de ese tipo depende totalmente de una investigación de base minuciosa que permita 
determinar los niveles de las poblaciones existentes $y$ de la aptitud para conducir la explotación en forma controlada. El alto nivel del comercio ilegal de productos de cocodrilos (94) hace pensar que el grado actual de control dista mucho de ser el adecuado en numerosas partes del mundo.

\section{AGRADECIMIENTOS}

Los fondos necesarios para la realización de esta encuesta fueron generosamente ofrecidos por la International Fur Trade Federation $y$ por la UICN. La realización de esta encuesta no hubiera sido posible sin la ayuda y colaboración acordada por las numerosas personas que respondieron a nuestras cartas y cuestionarios. Se hace referencia a esa ayuda cada vez que es posible y los autores desean expresar aqui mismo su inmensa gratitud. 
Table 1 Species of crocodilian mentioned in the text, giving the English names and status in the CITES Appendices.

CITES

Appendix

\section{Countries}

which hold

reservations

(July 1985)
Alligator mississippiensis

Alligator sinensis

Caiman crocodilus apaporiensis

Caiman crocodilus crocodilus

Caiman crocodilus fuscus

Caiman crocodilus yacare

Caiman latirostris

Melanosuchus niger

Paleosuchus palpebrosus

\section{Paleosuchus trigonatus}

Crocodylus acutus

Crocodylus cataphractus

Crocodylus intermedius Crocodylus johnsoni

Crocodylus moreletii Crocodylus niloticus

C. novaeguineae novaequineae

C. novaeguineae mindorensis (=Crocodylus mindorensis) Crocodylus palustris

\section{Crocodylus porosus}

Crocodylus rhombifer Crocodylus siamensis Osteolaemus tetraspis Tomistoma schlegelii Gavialis gangeticus
American alligator

Chinese alligator

Rio Apaporis caiman

Spectacled caiman

Brown caiman

Yacare caiman

Broad-nosed caiman

Black caiman

Dwarf caiman, Cuvier's

smooth-fronted caiman

Schneider's smooth-fronted II

caiman

American crocodile

African sharp-nosed

crocodile

Orinoco crocodile

Australian freshwater or II

Johntson's crocodile

Morelet's crocodile

Nile crocodile

(II in Cameroon ${ }^{*}$, Congo*, Kenya* Madagascar*, Malawi*, Mozambique*, Sudan $^{*}$, Tanzania* ${ }^{*}$ Zambia*, Zimbabwe ${ }^{+}$)

New Guinea crocodile II

Freshwater crocodile

Mindoro crocodile I

Mugger, marsh crocodile, I

broad-snouted crocodile

Estuarine crocodile,

Saltwater crocodile
(II in PNG, Australia ${ }^{+}$, Indonesia*)

Cuban crocodile I

Siamese crocodile I

W. African dwarf crocodile I

False gharial, false gavial I

Gharial, gavial
II

I

II

II

II

I

II

I

I

I Austria,

Zambia

II

Botswana, Sudan

Zambia, Zimbabwe

* subject to quotas

+ Ranching programmes 
Table 2. Quotas of $\mathrm{C}$. niloticus skins which may be exported from nine African Parties where the populations have been transferred to Appendix II.

Country

Cameroon

Congo

Kenya

Madagascar

Malawi

Mozambique

Sudan

Tanzania

Zambia
Estimated population

of C. niloticus
No. of

animals
5000

$40 \quad 000$

$40 \quad 000$

$30 \quad 000$

28300

202000

$250 \quad 000$

74000

$150 \quad 000$
20

1000

150

1000

500

1000

5000

1000

2000 
Table 3 species of crocodilian kept in different countries. KEY: $P$ : farmed on a large scale, $f$ : farmed on a small scale, $c$ : conservation/research operations, s: mainly conservation but some sales may take place, $p$ : proposed operations, ?: status uncertain.

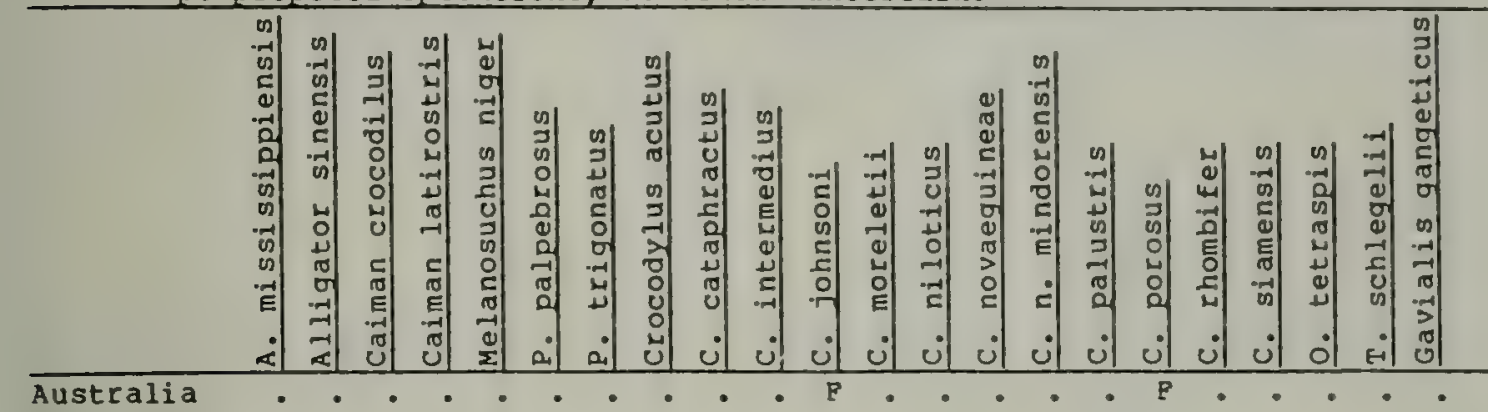

\begin{tabular}{l}
\hline Australia \\
Bangladesh \\
Bolivia \\
Botswana \\
Brazil \\
Brunei \\
Burma \\
Cameroon \\
Chad \\
China \\
Colombia \\
Costa Rica \\
Cuba \\
Ethiopia \\
Greece \\
India \\
Indonesia \\
Israel \\
Italy \\
Ivory Coast \\
Jamaica \\
Japan \\
Kenya \\
Madagascar \\
Malawi \\
Malaysia \\
Mali \\
Mauritius \\
Mexico \\
Mozambique \\
Nepal \\
Pakistan \\
PNG \\
Philippines \\
Rwanda \\
H. Samoa \\
Senegal \\
Singapore \\
South Africa \\
Spain \\
Sri Lanka \\
Suriname \\
Taiwan \\
Tanzania \\
Thailand \\
Togo \\
Uganda \\
USA \\
Uruguay \\
Venezuela \\
Zambia \\
Zimbabwe \\
\\
\hline
\end{tabular}


Table 4 Approximate numbers of each species of crocodilian kept on commercial farms in different countries. "?" indicates species is present, but numbers unknown.
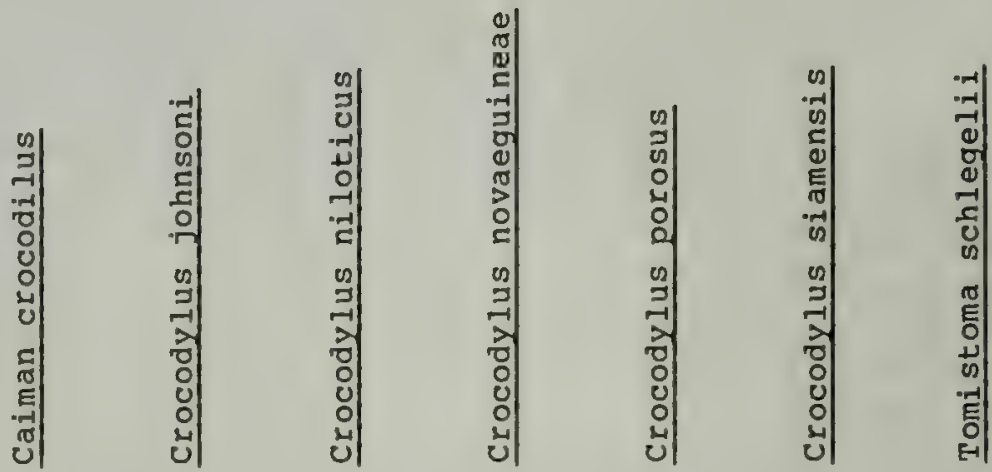

\section{Australia}

Bolivia

Botswana

Burma

Costa Rica

Ethiopia

Greece

Indonesia

I srael

Kenya

Madagascar

Malawi

Malaysia

Mali

Mauritius

Mozambique

PNG

Singapore

South Africa

suriname

Taiwan

Thai land

USA

Z ambia

zimbabwe

\begin{tabular}{|c|c|c|c|c|c|c|c|c|c|}
\hline- & - & 6612 & - & & - & 4351 & & - & - \\
\hline - & $?$ & - & - & & - & - & & - & - \\
\hline - & - & - & 70 & + & - & - & & - & - \\
\hline- & - & - & - & & - & 900 & + & - & - \\
\hline - & 100 & - & - & & - & - & & - & - \\
\hline - & - & - & $?$ & & - & - & & - & - \\
\hline - & - & - & 150 & & - & - & & - & - \\
\hline- & - & - & - & & $2000+$ & 1630 & + & $?$ & 120 \\
\hline 302 & - & - & 209 & & - & - & & - & - \\
\hline - & - & - & 1509 & & - & - & & - & - \\
\hline - & - & - & 454 & & - & - & & - & - \\
\hline - & - & - & $?$ & & - & - & & - & - \\
\hline- & - & - & - & & - & 2385 & + & - & 10 \\
\hline - & - & - & 34 & + & - & - & & - & - \\
\hline - & - & - & 88 & & - & - & & - & - \\
\hline - & - & - & 32 & & - & - & & - & - \\
\hline- & - & - & - & & 21000 & 9000 & & - & - \\
\hline - & - & - & - & & $?$ & 6600 & + & - & 24 \\
\hline- & - & - & 2204 & & - & - & & - & - \\
\hline- & ? & - & - & & - & - & & - & - \\
\hline- & 8000 & - & - & & - & 300 & & - & 15 \\
\hline 2 & 225 & - & - & & - & 1755 & & 7780 & 85 \\
\hline $49022+$ & - & - & - & & - & - & & - & - \\
\hline - & - & - & 2798 & + & - & - & & - & - \\
\hline- & - & - & 27704 & & - & - & & - & - \\
\hline 49326 & 8325 & 6612 & 35252 & & 23000 & 26651 & & 7780 & 254 \\
\hline
\end{tabular}


Table 5 summary of most recent figures for the stock, annual production, breeding and wild-collection of commercial crocodilian farms in different countries. Where no production had definitely been recorded the date of expected production is indicated.

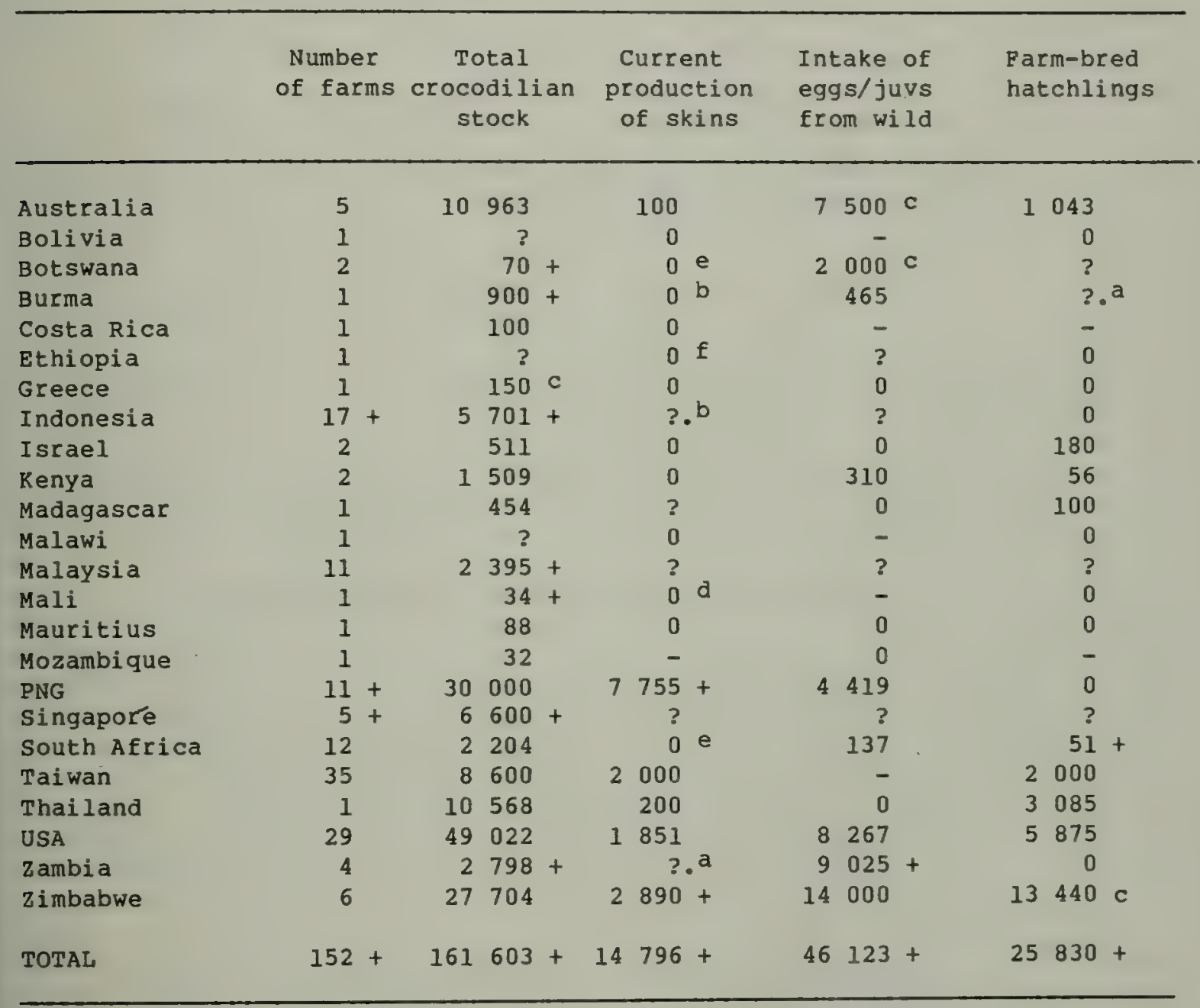

? Believed to occur, numbers unknown

- No information

a Planned for 1983

b Planned for 1984

c Planned for 1985

d Planned for 1986

e Planned for 1988

f Planned for 1989 

CONVENTION ON INTERNATIONAL TRADE IN ENDANGERED SPECIES

OF WILD FAUNA AND FLORA

SECOND MEETING OF THE CONFERENCE OF THE PARTIES

San Jose (Costa Rica), 19 to 30 March 1979

RESOLUTION OF THE CONFERENCE OF THE PARTIES

Specimens Bred in Captivity or Artificially Propagated

CONSIDERING that the Convention provides for special treatment of wildife that are bred in captivity and plant specimens that are artificially propagated;

RECOGNIZING the need for the Parties to agree on a standard interpretation of those provisions:

RECOGNIZING also the need to apply these provisions in a way that will not be detrimental to the survival of wild populations;

RECALLING that in the case of wildlife these provisions were intended to apply only to captive populations sustained without augmentation from the wild;

\section{THE CONFERENCE OF THE PARTIES TO THE CONVENTION}

\section{RECOMMENDS}

a) that the provisions of Article VII, paragraph 4, of the Convention be applied separately from those of Article VII, paragraph 5. Specimens of animal species in Appendix I bred in captivity for commercial purposes shall be treated as if they were in Appendix II, and shall not be exempted from the provisions of Article IV by the granting of certificates to the effect that they were bred in captivity or artificially propagated;

b) that the term "bred in captivity" be interpreted to refer only to offspring, including eggs, born or otherwise produced in a controlled environment, either of parents that mated or otherwise transferred gametes in a controlled environment, if reproduction is sexual, or of parents that were in a controlled environment when development of the offspring began, if reproduction is asexual. The parental breeding stock must be to the satisfaction of the competent government authorities of the relevant country:

i) established in a manner not detrimental to the survival of the species in the wild;

* This document was prepared after the meeting from document Com. 2.5 adopted after being amended. (Note from the secretariat). 
ii) maintained without augmentation from the wild, except for the occasional addition of animals, eggs or gametes from wild populations to prevent deleterious inbreeding, with the magnitude of such addition determined by the need for new genetic material and not by other factors, and

iii) managed in a manner designed to maintain the breeding stock indefinitely.

A controlled environment for animals is an environment that is intensively manipulated by man for the purpose of producing the species in question, and that has boundaries designed to prevent animals, eggs or gametes of the selected species from entering or leaving the controlled environment. General characteristics of a controlled environment may include but are not limited to artificial housing, waste removal, health care, protection from predators, and artificially supplied food. A parental breeding stock shall be considered to be "managed in a manner designed to maintain the breeding stock indefinitely" only if it is managed in a manner which has been demonstrated to be capable of reliably producing second-generation offspring in a controlled environment:

c) that the term "artificially propagated" be interpreted to refer only to plants grown by man from seeds, cuttings, callus tissue, spores or other propagules under controlled conditions. The artificially propagated stock must be:

i) established and maintained in a manner not detrimental to the survival of the species in the wild, and

ii) managed in a manner designed to maintain the artificially propagated stock indefinitely.

Controlled conditions for plants is under an environment that is intensively manipulated by man for the purpose of producing selected species. General characteristics of controlled conditions may include but are not limited to tilliage, fertilization, week control, irrigation, or nursery operations such as potting, bedding, or protection from weather; and

d) that the competent government authorities of countries exporting live animals, parts and derivatives of specimens bred in captivity of species listed in Appendix I endeavour, where possible, to ensure that these be made identifiable by means other than documentation alone. 
CONVENTION ON INTERNATIONAL TRADE IN ENDANGERED SPECIES OF WILD FAUNA AND FLORA

\section{THIRD MEETING OF THE CONEERENCE OF THE PARTIES New Delhi (India), 25 February to 8 March 1981}

RESOLUTION OF THE CONFERENCE OF THE PARTIES

\section{$\underline{\text { Ranching }}$}

CONSIDERING that the provisions of Article III of the Convention control international commercial trade in specimens of species included in Appendix I;

RECOGNIZING that this control of trade in species included in Appendix I is intended to improve the status of their wild populations;

RECOGNIZING that as a result of this control, the population of species included in Appendix I may vary between the countries in which they occur in the degree to which they are endangered;

RECOGNIZING the importance of maintaining Appendix I protection in those countries where the wild population is still endangered;

RECALLING that the terms of the Resolution on specimens bred in captivity or artificially propagated (Conf. 2.12), adopted at its second meeting (San Jose, 1979), do not allow the entry into trade of specimens of species included in Appendix I which have been reared in captivity following collection from the wild:

RECOGNIZING the desire of some Parties with successful programmes for the conservation of certain species to restore those species into international trade as soon as to do so is no longer detrimental to the survival of their wild populations of those species;

$$
\text { THE CONFERENCE OF THE PARTIES TO THE CONVENTION }
$$

\section{RECOMMENDS}

a) that populations of species included in Appendix I, which occur within the jurisdiction of Parties, but which are deemed by the Parties to be no longer endangered and to benefit by ranching (by

This document was prepared after the meeting from document Com. 3.12 adopted after having been amended. (Note from the Secretariat). 
which is meant the rearing in a controlled environment of specimens taken from the wild) with the intention of trade be included in Appendix II;

b) that, in order to be considered by the Parties, any proposal to transfer a population to Appendix II in order to conduct a ranching operation satisfy the following general criteria:

i) the operation must be primarily beneficial to the conservation of the local population (i.e., where applicable, contribute to its increase in the wild); and

ii) the products of the operation must be adequately identified and documented to ensure that they can be readily distinguished from products of Appendix I populations;

c) that for obtaining approval for transfer to Appendix II of the country's population, or a smaller geographically separate population of the species involved, in order to conduct a ranching operation, the Management Authority submit a proposal to the secretariat, such a proposal containing the following:

i) evidence that the taking from the wild shall have no significant detrimental impact on wild populations;

ii) an assessment of the likelihood of the biological and economic success of the ranching operation;

iii) assurance that the operation shall be carried out at all stages in a humane (non-cruel) manner;

iv) assurance that the operation will be beneficial to the wild population through reintroduction or in other ways;

v) a description of the methods to be used to identify the products through marking and/or documentation; and

vi) assurance that the criteria continue to be met, with records open to scrutiny by the secretariat, and that the Management Authority shall include in its reports to the secretariat sufficient detail concerning the status of its population and concerning the performance of any ranching operation to satisfy the parties that these criteria continue to be met; and

d) that in order to be discussed at the next meeting of the Conference of the Parties any proposal for amendment of the appendices pursuant to this resolution be received by the secretariat at least 330 days before that meeting; the Secretariat will consult with the standing Committee in seeking such appropriate scientific and technical advice to verify that 
the criteria specified under b) and c) have been met; if in the

opinion of the secretariat further information concerning the criteria is required, the secretariat shall request information from the proposing Party within 150 days after receipt; thereafter, the Secretariat shall communicate with the Parties in accordance with Article XV of the Convention. 


\title{
CONVENTION ON INTERNATIONAL TRADE IN ENDANGERED SPECIES OF WILD FAUNA AND FLORA
}

\author{
FOURTH MEETING OF THE CONFERENCE OF THE PARTIES \\ Gaborone (Botswana), 19 to 30 April 1983
}

RESOLUTION OF THE CONFERENCE OF THE PARTIES

Control of Captive Breeding Operations in Appendix I Species

RECOGNIZING that under the provision of Article VII, paragraph 4, of the Convention, specimens of species included in Appendix I which are bred in captivity for commercial purposes shall be deemed to be specimens of species included in Appendix II;

RECALLING that Resolution Conf. 2.12, adopted at the second meeting of the Conference of the Parties (San Jose, 1979), precisely defines the expression "bred in captivity";

AWARE that any exemptions may lead to abuses, notably from states which are not Parties to the Convention;

CONSIDERING that a uniform implementation of the provisions of the Convention is necessary for it to function well;

THE CONFERENCE OF the PARTiEs to the CONVENTION

\section{RECOMMENDS}

a) that Parties provide the secretariat with any appropriate information on the operations occurring in their territories which regularly breed in captivity, for commercial purposes, specimens of species included in Appendix I to which Article VII, paragraph 4, of the Convention applies, or, if appropriate, that they inform the secretariat that such operations do not exist;

b) that Parties strictly implement the provisions of Article IV of the Convention with respect to specimens of species included in Appendix I originating from operations which breed such specimens in captivity for commercial purposes;

c) that Parties reject any document granted under Article VII, paragraph 4, of the Convention, if the specimens concerned do not originate from an operation duly registered by the secretariat;

d) that comparable documentation granted under Article VII, paragraph 4 , of the Convention by states which are not Parties to the Convention not be accepted by the Parties without consultation with the secretariat; and 
e) that Parties collaborate as much as possible on the survey on Farming and Ranching undertaken by the Wildlife Trade Monitoring Unit (WTMU); and

REQUESTS the Secretariat to compile and update a Register of the operations which breed specimens of species included in Appendix I in captivity for commercial purposes, on the basis of the information received from the Parties and other sources, and that it communicate this Register to the Parties. 



\section{Crocodilian farming operations}

The following section reviews the status of crocodilian farming by country. Countries are arranged in alphabetical order. Wherever possible details of individual farms have been presented. 



\section{AUSTRALIA}

Crocodile harvesting in the past has caused depletion of the crocodile populations in Australia. The saltwater crocodile Crocodylus porosus was particularly severely affected and the species was protected in 1971. As a result of protection the numbers increased and in 1983 the Australian Council of Nature Conservation Ministers (CONCOM) prepared a proposal for the fourth meeting of the Conference of the Parties to CITEs, at Gabarone, Botswana, to transfer the Australian population of $C$. porosus to Appendix II supported by a ranching programme. This proposal was withdrawn prior to the meeting in the face of opposition from the IUCN/SSC Crocodile specialist Group. The proposal was rewritten after the collection of further information on the status of crocodile populations and submitted to the fifth CITES meeting, at Buenos Aires, Argentina, in 1985, where it was approved.

The first crocodile farm was established in Queensland in 1973 and achieved captive breeding shortly afterwards. In 1984 it became the second farm in the world to be registered with the CITES secretariat as a recognised captive-breeding operation. A further three farms were established in the Northern Territory and one in queensland in the early 1980 s.

The Conservation Commission of the Northern Territory, which carries out much of the research on crocodile biology, has supervised the wild-capture of the animals held on the three farms in the Territory. It has organised trials to quantify a sustainable level of annual harvest within specified management areas. A number of animals have been removed from areas in which they were considered a potential hazard to the public (51).

All stages of the farming process are subject to regulatory control. Licences to farm are only granted to those with suitable experience, and require prior submission of farm design, husbandry, development and financial plans. Licensees are required to submit monthly reports of stock and are subject to random spot checks by the Conservation Commission. Permits are required to slaughter stock, the dates of slaughter being specified, and serially numbered tags are issued for all skins. Tag numbers are specified on permits for all skins exported. The Conservation Commission keeps computer records of all farms, which allows for checking of authorised stocks and skins at all times (192).

A trial egg harvest for $C$. porosus has been proposed which would involve the taking of 4000 eggs a year for three years from the Northern Territory. These eggs will be supplied to the three farms in the Territory. No harvest is planned for Queensland. Hatchlings totalling $5 \%$ of the number of eggs collected must be made available for release at one year old should this be required by the Conservation Commission.

A trial harvest of up to 200 juvenile $\mathrm{c}$. porosus $(0.6-2 \mathrm{~m}$ ) was planned to assess the effect of this in comparison to egg harvest.

Experience with rearing $C$. johnsoni has shown that $90 \%$ survival to slaughter age is expected. Some problems with feeding in $C$. porosus have resulted in survival falling to 50\%, but the Edward River Farm in Queensland has demonstrated $80 \%$ survival with a minor alteration to the diet (192). 
Both species have bred on farms and it is expected that 100 nests of C. porosus will be laid on farms in 1984/85 (70 in Queensland and 30 in Northern Territory), equivalent to 5200 eggs. Less than 58 of the eggs of later clutches are infertile although the percentage is higher in first clutches (192).

All the farms are associated with enterprises which supply food at minimal cost. In 1984 Government economists re-assessed the long-term financial viability of farms and found them favourable, even given the prevailing depressed skin prices. The financial analysis assumed at least a $5 \%$ return of raised juveniles to the wild. A trial harvest of c. porosus eggs in $1983 / 84$ showed that collection by helicopter and incubation costs amounted to $A \$ 5$ a hatchling, and that the cost of raising each hatchling to a size of 5-6 ft was $A \$ 30-40$. The skin of an animal of this size was worth $\mathrm{A} \$ 150-180$ in 1984 (192).

Whitaker et al. (204) quoted the prices of dried meat and gall bladders in Australia as US\$15 $\mathrm{kg}^{-1}$ and $U S \$ 245 \mathrm{~kg}^{-1}$ respectively in 1985.

\section{The operations}

\section{Northern Territory}

NAME OP OPERATION

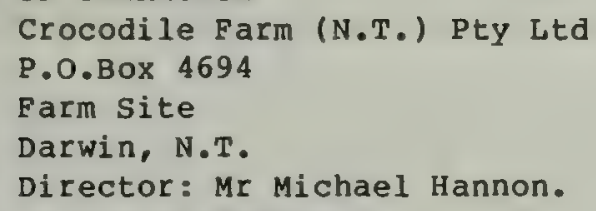

The stock of Crocodylus johnsoni and Crocodylus porosus held in June 1984 (192) or December 1983 (51) was:

\begin{tabular}{|c|c|c|c|c|}
\hline Species & Hatchlings & Juveniles & Adults & TOTAL \\
\hline C. porosus & 331 & 185 & 108 & 624 (192) \\
\hline c. johnsoni & 1089 & 1194 & 96 & $2379(51)$ \\
\hline- & & & & $2368(192)$ \\
\hline
\end{tabular}

PRODUCTION AND TRADE

The farm has not started production but expects to do so in 1985. Trade is expected to involve the export of raw hides to Asian and European markets (51).

SOURCE OP ANIMALS

The animals have been obtained as eggs, hatchlings and some adult 'problem animals', from the wild under the supervision of the Conservation Commission of the Northern Territory (51). BREEDING

It was anticipated that $C$. porosus would produce up to 30 clutches of eggs on this farm in 1984/85. At a mean clutch size of 52 this would represent up to 1560 eggs (192). 


\section{OTHER INFORMATION}

It was reported in 1983 that this farm was involved with the tourist side of the industry (187). The farm has made a substantial investment in tourist facilities from which some return is being realised (51).

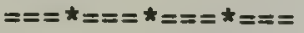

NAME OP OPERATION

Letaba Crocodile Rearing station

P.O. Box 2351

Darwin N.T. 5794.

Operated by: Hilton D. Graham.

DATE OF ESTABLISHMENT

The operation was established in 1982 (51). In June 1983 the farm was still under construction (88), but was in operation by late 1984 (192).

SPECIES AND NUMBERS

The stock of Crocodylus johnsoni and Crocodylus porosus held in June 1984 (192) or December 1983 (51) was:

\begin{tabular}{|c|c|c|c|c|}
\hline Species & Hatchlings & Juveniles & Adults & TOTAL \\
\hline c. porosus & 172 & 49 & 0 & $221(192)$ \\
\hline c. johnsoni & 1820 & 0 & 0 & 1820 (51) \\
\hline
\end{tabular}

PRODUCTION ATD TRADE

The farm has not started production but expects to do so in 1985. Trade is expected to involve the export of $r a w$ hides to Asian and European markets (51).

SOURCE OR ANIMALS

In June 1983 a small "nucleus" stock of crocodiles for Letaba Crocodile Rearing station was being held at Janamba Crocodile Farm (88). All of the animals held were obtained as eggs, hatchlings and some adult 'problem animals', from the wild under the supervision of the Conservation Comnission of the Northern Territory (51).

$$
==\approx *=ニ *==+*===
$$

NAME OF OPERATION

Janamba Crocodile Farm

Box 92

Humpty Doo

NT 5791.

The Director of the farm was Alistair Graham, but recent reports suggest that he no longer holds this post.

DATE OP ESTABLISHMENT

November 1982 
SPECIES AND NUMBERS

The stock of Crocodylus johnsoni and crocodylus porosus held in June 1984 (192) or December 1983 (51) was:

\begin{tabular}{lcccc} 
Species & Hatchlings & $\frac{\text { Juveniles }}{807}$ & $\frac{\text { Adults }}{24}$ & $\frac{\text { TOTAL }}{838(192)}$ \\
$\frac{\text { C. porosus }}{\text { C. johnsoni }}$ & - & 0 & $2589(51)$ \\
\hline & & & 0 & $2389(192)$
\end{tabular}

\section{PRODUCTION AND TRADE}

Skins are to be produced but production has not yet started (86). It was expected to begin production in 1985 for export to European and Asian markets (51).

SOURCE OF ANIMALS

The numbers of animals obtained from the wild up to mid-1983 were:

$\begin{array}{lcc}1982 & \frac{\text { Adults }}{-} & \frac{\text { Juveniles }}{3300} \\ 1983 & 5 & -\end{array}$

Survival rate of hatchlings was 1008 until unsuitable diet caused a loss of nearly $9 \%$, the problem is now thought to have been resolved. In 1982 the operation was based on the harvest of hatchlings but in 1983 egg harvesting was to be tried as an alternative. BREEDING

Regulations are set by the Government to control wild capture (86). eventua $11 Y$.

HUSBANDRY

The crocodiles are kept in open-air enclosures with aquatic vegetation; feeding is on a daily basis with a mixture of poultry, fish and beef (86). The second partner in the operation runs a chicken farm which provides ex-production birds as the main food supply for the crocodiles (87).

\section{FINANCES}

The operation was financed by $M r$ Graham and a partner but is expected to become self-financing after production has been under way for a while (87).

RESEARCH AND PUBLICATIONS

Research was carried out by Alistair Graham in collaboration with the Conservation Commission of the Northern Territory (86). OTHER INEORMATION

All wild animals in the N.T. remain the property of the Government so that control of the resource is entirely in their hands. Regular reports are made to the Government on all management activities, with a view to publication (86). 


\section{Queensland}

\section{NAME OF OPERATION}

Ltd)

Edward River Crocodile Farm Pty Ltd (formerly Applied Ecology Pty

Edward River, Cape York, Queensland 4871

Postal address:

$$
\begin{aligned}
& \text { P.O.Box } 669 \\
& \text { Cairns } \\
& \text { Queensland } 4870 .
\end{aligned}
$$

DATE OF ESTABLISHMENT

The operation started in 1973 and aimed to start production and commercial operation in 1984 (134). The farm was registered with the CITES Secretariat as an approved captive-breeding operation for Crocodylus porosus in November 1984.

SPECIES AND NUMBERS

Crocodylus porosus, stock in 1980 (133):

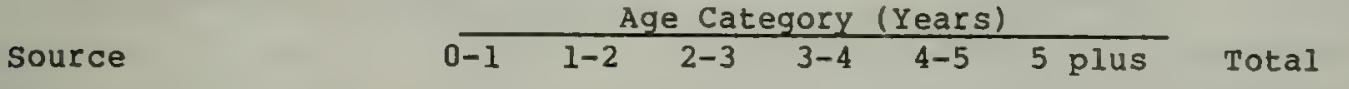

Wild-caught

Wild-taken Eggs/

Farm-raised

Farm-bred and

-raised

Total

\begin{tabular}{rrrrrrr}
- & - & - & - & - & 75 & 75 \\
90 & 27 & 132 & 34 & 18 & 87 & 388 \\
159 & 25 & - & - & - & - & 184 \\
\hline 249 & 52 & 132 & 34 & 18 & 162 & 647
\end{tabular}

(160).

In 1983 the number of c. porosus was 1006, plus 627 hatchlings

PRODUCTION AND TRADE

The operation produces skins and live animals. In 198040 skins were produced under licence as part of a feasibility study for commercial production. When commercial production was envisaged in 1980, a figure of 3000 skins a year was the proposed output and this figure remained the production target for commercial operations to begin in 1984 (134). It is proposed that all killing and skinning operations will be carried out on the farm and thus the farm staff have been instructed in the various skills required (133).

Live animals have been sold to zoos, for research and to other crocodile farms.

\section{Live animal production 1980-83 (134):}

\begin{tabular}{lrl} 
Year & Number of animals & Destination \\
\cline { 1 - 1 } & 5 & Zoos \\
1980 & 10 & Zoos \\
1981 & 35 & Zoos and research \\
1982 & 20 & Breeding stock for another farm \\
1983 & &
\end{tabular}

In 198040 skins were sold to destinations in Australia, France, singapore and Italy. All live sales have been within Australia. All 
specimens and skins are accompanied by required state and/or federal permits (134). The first commercial export of 100 skins to singapore took place in 1984 .

SOURCE OF ANIMALS

The farm had received many wild-caught animals up to 1979. The operation was originally established primarily as a conservation-orientated project; so most of the animals were eventually released back into the wild. In 1979 wild capture ceased and the operation became a closed cycle (134).

\section{BREEDING}

C. porosus have been bred on the farm for a number of years. The breeding stock of about 100 females is kept separate from the rearing pens and eggs are hatched in an artificial incubator.

\section{Breeding success $1980-83$ (134):}

\section{Year}

Number bred

in captivity.

1980

1981

1982

1983

1984

\section{9}

302

591

769

1043

\section{Number survived}

30 days.

140

267

561

741

The survival rate to 30 days has therefore increased from 788 in 1980 to 968 in 1983.

It is anticipated that 70 clutches of $\mathrm{C}$. porosus eggs will be laid on the farm in 1984/85. At a mean clutch size of 52 this would represent 3640 eggs (192).

HUSBANDRY

The large breeding crocodiles are kept in a natural enclosed lagoon covering about 20 ha with a water area, when full, of 13 ha. Hatchlings after incubation are kept in tanks in a large shed until they start to feed. From the tanks the young crocodiles are then transferred to a series of 16 pens all with continuously flowing water.

The crocodiles are moved through the series of pens as they grow, until an age of $2-3$ years when they are moved to 'finishing' enclosures. These enclosures are 2.2 ha each with 1 -ha water areas, and house the animals until they reach optimum size of belly skin width $40 \mathrm{~cm}$ and $1.5 \mathrm{~m}$ body length (about four years of age). The creek systems are drained and swept out six times a week, whereas the enclosures are permanent water areas. Bore water is pumped into all enclosures in the dry season.

The breeding lagoon animals are fed once a week, those in the finishing enclosures five times a week, and those in the rearing pens six times a week, on a variety of foods including wild-pig, scrub cattle and fish, with a vitamin and mineral supplement (134).

PINANCES

The farm is run by a private company (Edward River Crocodile Farm Pty Ltd) owned and funded by the Australian Government through the Department of Aboriginal Affairs. In 1984 the operation was not self-financing (134). 


\section{RESEARCH AND PUBLICATIONS}

Research is carried out by Professor Gordon Grigg, of sydney University, who visits each year for $3-4$ weeks with some of his post-graduate students (134).

In the past there have been other research workers including steve Garnett of James Cook University of North Queensland who looked at various components of the farming operation (133).

OTHER INFORMATION

The operation changed from Applied Ecology Pty Ltd to Edward River Crocodile Farm Pty Ltd on 1 July 1983. Applied Ecology used to be involved with a number of projects associated with wildife management and the Aboriginal and Torres strait Islander communities, but this involvement has now ceased.

The farm was established primarily as a conservation measure but later shifted emphasis to researching the viability of crocodile farming and the development of a commercial farm (13). It is hoped that as soon as production, processing techniques and markets are firmly established, the farm will be handed over to the Edward River Aboriginal community. The operation should provide direct employment for at least 15 Aborigines and would form the basis of the community's first major income-producing enterprise. (16)

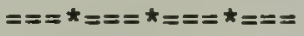

NAME OP OPERATION

Koorana Crocodile Farm

M.S.F. $7 \overline{6}$, Rockhampton Mail Centre

Rockhampton

Queensland 4700 .

Operated by: John Lever.

DATE OF ESTABLISHMENT

1981

SPECIES AND NUMBERS

Crocodylus porosus 111

Crocodylus johnsoni 148 in June 1984 (192)

PRODUCTION AND TRADE

Production had not started by 1984 , but is expected to involve skins and by-products such as gall bladders and 'musk glands'. The skins are to be exported to French tanneries (161).

SOURCE OP ANIMALS

Crocodylus porosus: native animals are collected after being declared rogue by the Queensland National Parks and wildlife Service.

Crocodylus johnsoni: 200 animals ( 60 adults and 140 juveniles) were removed from the wild under permit in conjunction with a Queensland National Parks and Wildife Service research programme. It was expected that no further introductions from the wild would be necessary and that the operation would become a closed cycle (122).

Four $\mathrm{C}$. johnsoni and two $\mathrm{C}$. porosus have been obtained from other captive stocks. In July 1983 the farm was reported to be negotiating with Edward River Crocodile Farm to purchase 30 female C. porosus (161). BREEDING

The C. porosus were put together for mating in 1983 for the first time $(122)$. It is not known whether successful breeding occurred. 
Australia

\section{HUSBANDRY}

The crocodiles are held in 25 concrete tanks with wire enclosures, 7 dams (reservoirs) and one lake. All of the crocodiles are fed fish and poultry (122).

BINANCES

The operation is financed by a private individual and was not self-financing in 1983 (122).

RESEARCB AND PUBLICATIONS

Research was planned in conjunction with the Queensland National Parks and Wildlife Service and the Capricorn Institute for Advanced Education (122). 


\section{BANGLADESH}

General Information:

In 1982 Whitaker (198) proposed the establishment of a central crocodile hatchery and nursery and four model crocodile demonstration ranches. The main species involved would be Crocodylus porosus and Gavialis gangeticus. Breeding would be carried out on an experimental basis. The major part of the operation would involve taking $c$. porosus eggs from the wild in the Sunderbans and rearing them for skin trade and release to the wild. It was proposed that the system should be established by the sunderbans Forest Department with the central hatchery situated at Dhangmari, Sutar Khali, Chandpai and the four model demonstration farms at Khulna, Dacca, Chittagong and sythet (198). As far as is known no steps had been taken to implement the proposal by 1985 .

The plan was to rear $C$. porosus to $1 \mathrm{~m}$ for release to the wild and to $1.75 \mathrm{~m}$ for cropping. The central hatchery would supply 6-months to 1-year-old crocodiles to the Demonstration farms. The Demonstration farms' eventual output would be 250 skins a year, plus a number of yearlings for restocking the sunderbans. Crocodylus palustris and $G$. gangeticus are considered unsuitable for this sort of ranching in Bangladesh because of their low populations. However, the Central Hatchery would hatch and rear some $C$. palustris from eggs collected at Bagerhat, near Khulna. The Dacca model demonstration farm would also hatch and rear some $G$. gangeticus from eggs collected at Rajshahi.

A study of wild living crocodiles wauld need to be undertaken to establish a management scheme for sunderbans crocodile populations and for identifying areas for restocking with farm-reared animals (198).

In Bangladesh in 1982 it was estimated that there was a total captive population of three $C_{\text {. porosus, }}$ five $G$. yangeticus and three $C_{\text {. }}$ palustris (197). 


\section{BOLIVIA}

ASICUSA (Asociacion de Curtidones de Cueros de Saurios), based in Cochabamba and comprising four companies, Tomy, Alligator, Dorado and Moxos, all involved in the tanning and processing of caiman skins in Bolivia, was reported in 1982 to be establishing a crocodilian farm in Bolivia (46). In 1983 it was claimed that the stock included 2000 crocodilians comprising Caiman crocodilus crocodilus, Caiman crocodilus yacare, Melanosuchus niger and "another species of Caiman" (47). However Quaino, Director of "Moxos" Alligator Ranch, Casilla Correo No. 44, Trinidad-Beni, stated that his ranch was only in a very preliminary phase and contained only Caiman crocodilus in 1983 (151). It is extremely unlikely that any breeding has taken place on any farm in Bolivia. A report in 1982 stated categorically that no breeding had occurred at that stage (46). 


\section{BOTSWANA}

Two farms for Crocodylus niloticus are reported to have been established since 1983 in Botswana:

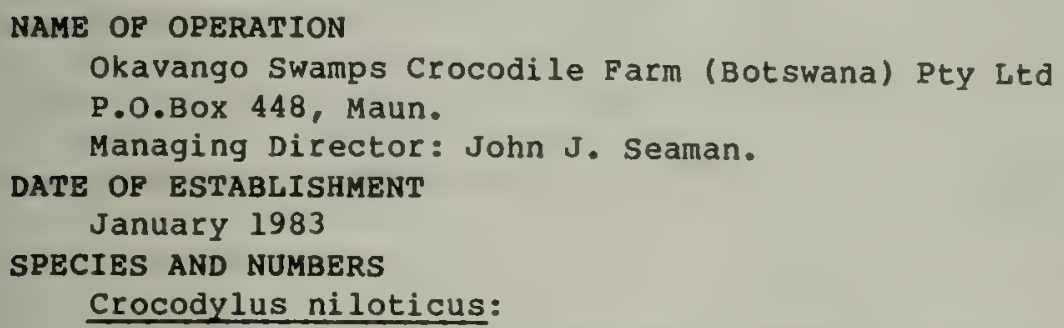

It is hoped to sell live animals to other farmers and zoos. SOURCE OR ANIMALS

70 adult crocodiles have been captured in local drought areas where they were thought to be under threat. It was anticipated that in 1984 there would be another severe drought and facilities were being built to cater for a larger number of crocodiles. It was planned to collect 2000 eggs a year over the following three seasons. It was also planned to reinstate $5 \%$ of the $1-m$ sized crocodiles into the wild (162).

A number of crocodiles were caught in 1984 at Lake Ngami which was badly affected by the drought. Several nuisance crocodiles have been obtained after complaints of attacks on livestock or humans (144). BREEDING

The crocodiles had just started breeding in 1983. It was hoped that the breeding stock could be built up to 300 over the next three years (162). Successful breeding was also reported in 1984 (144).

HUSBANDRY

The animals are kept in near-natural pools in a typical okavango back-water area. Water access is from a main stream nearby. There is a dual perimeter fence made of reeds. The pens are $45 \mathrm{~m}$ long and $40 \mathrm{~m}$ wide covered two thirds by water of varying depths with islands and the natural vegetation (162). A temperature-controlled building is used for rearing hatchlings (144).

The crocodiles are reported to stop feeding for four months in the winter when the temperature falls below $20^{\circ} \mathrm{C}(144)$. They are fed on donkey meat and catfish (162).

\section{FINANCES}

It is intended that most of the income will be obtained from the sale and export of live animals. Tourists are also admitted to the farm (144). The operation was not self-financing in 1983, being supported by private investment (162).

The farm employs 53 local people (144).

RESEARCH AND PUBLICATIONS

Research is planned in conjunction with the Rockefeller Refuge, Louisiana, USA (162).

$=ニ * *=* *=ニ=*=ニ=$

Another farm was reported to have been established in Botswana in 1984 by Mike Slogrove, the owner of a crocodile farm in Transvaal, South Africa (54). 
No commercial crocodilian farming has taken place in Brazil but I.B.D.F. (Instituto Brasileiro de Desenvolvimento Florestal) has initiated some experimental farming of Caiman crocodilus. One breeding centre operated by I.B.D.F. outside Manaus, the Centro Experimental de Criaçao em Cativeiro de Animais Nativos de Interêsse Cientifico e Econômico (CECAN), formerly held small numbers of Caiman crocodilus and Paleosuchus trigonatus but these have since been disposed of.

Melanosuchus niger is kept in small numbers only by zoos and research institutes.

\section{NAME OF OPERATION}

An experimental farm has been set up in Pantanal about $150 \mathrm{~km}$ from Pocone, Mato Grosso. The project is managed by:

Instituto Brasileiro de Desenvolvimento Florestal (I.B.D.F.)

Ed. Palacio Desenvolvimento, $12^{\circ}$

70.000 Brasilia-DF

SPECIES AND NUMBERS

Caiman crocodilus yacare: numbers unknown

DATE OF ESTABLISHMENT

1981

OTHER INFORMATION

The aim of the project is to evaluate the possibility of caiman ranching in the Pantanal. Eggs are collected from the wild, incubated and hatchlings are to be released later. Few results are available as yet. (154).

There is also some experimental work with capybara at the farm 


\section{BRUNEI}

A combined fish and crocodile farming operation (Crocodylus porosus?) is under consideration. A feasibility study was being carried out in 1984 (43). 
Only one crocodile farm is known to exist in Burma:

NAME OP OPERATION

The People's Pearl and Fisheries Corporation Crocodile Farm (PPFC)

Thaketa, Rangoon.

Operated by: The Government of the Socialist Republic of the Union of Burma (63).

DATE OF ESTABLISHMENT

1978

SPECIES AND NUMBERS

Crocodylus porosus: about 900 were held in 1980 (63).

PRODUCTION AND TRADE

The main aim of the farm is to produce skins but it is thought that in 1983 no animals had reached marketable size (158).

SOURCE OF ANIMALS

Young animals are taken as hatchlings or yearlings from the eastern side of the Irrawaddy Delta where the PPFC has set up a number of collection centres. There is evidence that the total recruitment of crocodiles was being taken by the PPFC in the Tawbaing chaung area (63). From 1978 to 1983 an average of 465 hatchlings were obtained from the wild each year (158).

BREEDING

The farm is intended to be self-sustaining when its breeding programme is fully established. Successful breeding was expected by 1983 (63). The farm has recently been successful in inducing nesting but most of the stock of hatchiings continues to come from the remaining wild population in the Irrawaddy Delta (158).

HUSBANDRY

Young animals are kept in a series of tanks and there is a 1.5-ha breeding/nesting enclosure (158).

RESEARCH AND PUBLICATIONS

Research is to be carried out by U. Aung Moe, under the direction of $U$. Than Nyunt (farm manager), with possible help from an FAO consultant, in an honorary capacity, if necessary. The proposed research is into food quality and quantity required for maximum growth rates (63).

OTHER INPORMATION

The crocodile farm is a large, modern, commercial enterprise modelled on farms in Thailand and Singapore (62). The PPFC has also proposed to turn Meinmahla Kyun, an island of some 50 square miles in the Irrawaddy Delta, into a 'crocodile sanctuary' where re-introductions from the the crocodile farm would supplement the remaining wild population and provide the basis for eventual sustained-yield harvest (158).

The farm was reported to be in need of technical and development assistance in 1984 (201). 


\section{CAMEROON}

A French/Belgian concern is reported to be planning a crocodile farming project in the Cameroon with the intention of exporting skins (43). 


\section{CHAD}

An experimental programme to evaluate the possibilities of crocodile farming (Crocodylus niloticus) was undertaken from 1972 to 1973 under the auspices of the Centre Technique du Cuir, Lyon (119). The farm was situated at Djimtilo, a vilage near Lake Chad, and funding was partially supplied by the Centre Technique Forestier Tropicale (C.T.F.T.), 45 bis Avenue de la Belle Gabrielle, 94130 Nogent-sur-Maine, France (119). Although much valuable information was obtained during this experiment, it was not intended to be a commercial proposition but merely to assess the possibilities of breeding crocodiles under controlled conditions. It is understood that the experiment was discontinued in 1973 (188).

An experimental crocodile farm was reported to have been started in 1943 but since the "recent disturbances" it is believed to have been abandoned (43). 
A substantial investment has been made in alligator ranching/ farming by both national and local authorities in China. There is a growing number of operations, mainly intended as conservation measures, but there is considerable potential for sale of live animals or products derived from them (189). There are unconfirmed reports that sales of alligators may have taken place (29). sinensis:

Huang Chu-Chien (98) names five operations managing Alligator

Name of operation

Anhui xuancheng farm

Chekiang Anchi farm

Chekiang Changhsing farm

Chekiang Ningpo zoo

Shanghai zoo
Number of adults

100 plus

3

7

3

10
Number of juveniles

380

$-$

$-$

11

27

The first of these is the only one operating on a large scale at the moment.

\section{NAME OF OPERATION}

Xiadu Commune Tree rarm

Xuancheng County, Anhui Province.

Operated by: Forestry Bureau, Anhui Province.

\section{SPECIES AND NUMBERS}

Alligator sinensis: The station held about 90 individuals, mostly adults, in July 1981 (89). By summer 1982 Huang reported some 130-140 animals on the farm (190). In 1983 he reported the presence of over 100 adults and 380 juveniles $(98)$.

PRODUCTION AND TRADE

Chinese alligators are not known to be used for food or skins (190), but there are unconfirmed reports of commercial sales from this farm $(29)$.

\section{SOURCE OP ANIMALS}

Peasant excavations of alligator dens are frequent in mountainous areas of Anhui Province. Animals captured are sold to dealers who, in turn, try to sell them to zoos or to the alligator farm.

Local residents are being encouraged to bring alligators that they capture to the farm rather than kill them or sell them elsewhere. The farm will pay in excess of one yuan a pound (US\$1.32 $\mathrm{kg}^{-1}$ ). Alligator eggs are also bought at one yuan each. It is reported that even eggs that have been rotated, and so are probably dead, are bought (190).

Local workers are also asked to inform farm personnel of the presence of nests containing eggs within their communes (89).

BREEDING

No captive breeding is known but wild-collected eggs are incubated. Over 200 wild-taken eggs were incubated in 1981: approximately 40 hatched of which 24 survived until hibernation in October; 18 survived the winter but all died before the summer of 1982 (190). In 1983300 alligators were sucessfully hatched (201). HUSBANDRY

In 1981 the farm consisted of two triangular concrete pools with sloping bottoms, c. $10 \mathrm{~m} \times 10 \mathrm{~m} \times 15 \mathrm{~m}$ (curved side), the maximum water 
depth being $2 \mathrm{~m}$ but not constant; several 'natural type' pools dug straight into the earth, each containing four to seven adult female alligators, and measuring approximately $4 \mathrm{~m} \times 5 \mathrm{~m} \times 3 \mathrm{~m}$ deep but providing no cover for the alligators; and a large circular pool $30 \mathrm{~m}$ in diameter with a circular central island $20 \mathrm{~m}$ in diameter and stocked with 60 adult alligators and several turtles (Chinemys reevesi). The large circular pool has concrete walls and a mud bottom, with a maximum water depth of $1 \mathrm{~m}$. The island has $0.3-\mathrm{m}$ concrete pipes placed around its periphery in which the alligators shelter: it was also planned to plant the island with bamboo (190).

The farm has no natural alligator habitat and no natural water supply above ground (190), but a large natural enclosure was scheduled for completion in 1984 (201).

The alligators are fed several times a week on locally available freshwater fish and live ducklings (190).

PINANCES

The farm receives financial support from the Ministry of Forestry in Central Government (189).

OTHER INFORMATION

The farm covered an area of 89 ha in 1981 but there were plans to increase this to 3335 ha $(190)$.

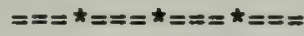

NAME OP OPERATION

"Wan" Production Unit

Cheunghing County (=Changhsing?)

Chekiang Province.

SPECIES AND NUMBERS

HUSBANDRY

Alligator sinensis: 10 adults (23).

The farm covers a total area of 500 acres of groves of bamboo and trees. Two acres of ponds have been fenced off as a production unit (23).

FINANCES

The farm receives limited financial support from the Provincial Porestry Bureau (189).

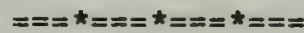

\section{NAME OP OPERATION}

Ling Fung Temple plantation,

Ankut County (=Anchi?),

Chekiang Province.

SPECIES AND NUMBERS

HUSBANDRY

Alligator sinensis: more than 10 alligators (23).

The farm covers 50 acres of bamboo groves, 1.2 acres of ponds and 70 acres of paddy fields and open space (23).

PINANCES

The farm receives limited financial support from the Provincial Forestry Bureau (189). 


\section{OTHER INFORMATION}

Another farm is planned at Yeehing Caves, Kiangsu Province, for the purpose of tourist viewing (23).

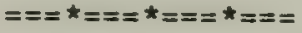

NAME OP OPERATION

Shanghai zoo

Shanghai.

SPECIES AND NUMBERS

BREEDING

Alligator sinensis

There has been considerable success in breeding Yangtze alligators. Five adults have had clutches of eggs ranging in size from 8 to 4l. Eggs are laid early in the morning over a period of about 30-40 minutes. Incubation lasts 67-83 days.

12 young were hatched in 1980 and 7 in 1981 (191). HOSBANDRY

Growth rate varied with the feeding regime. Of three groups of young, the fastest-growing group reached $60 \mathrm{~g}$ in one month, $270 \mathrm{~g}$ after a year and $800 \mathrm{~g}$ after two years. Comparable figures for the slowest-growing group were $24 \mathrm{~g}, 65 \mathrm{~g}$ and $230 \mathrm{~g}$

Adults were fed on fish and waste from a slaughter-house (23).

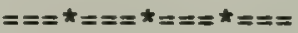

NAME OP OPERATION

Ningpo zoo

Chekiang Province.

SPECIES AND NUMBERS

BREEDING

Alligator sinensis

The $\mathrm{zoo}$ has bred from one pair of adults. Eggs were laid on 12 August 1982, and after artificial incubation the first hatched on 21 october. After five days there were a total of 9 with a mean weight of $29.5 \mathrm{~g}$ and length of $20 \mathrm{~cm}$ (23).

$==* \star==*$ * $=* *==$

NAME OF OPERATION

Beijing zoo

Beijing.

SPECIES AND NUMBERS

Alligator sinensis: over 30 adults (23).

BREEDING

A 'single egg was laid in 1982 but it was hoped that breeding in outdoor pools would start in 1983 (23).

BUSBANDRY

The enclosure was reported to be extremely over-crowded in 1981, and barely suitable for 10 animals (191). 
China

NAME OP OPERATION

Swato Crocodile Farm.

DATE OP ESTABLISHMENT

Prior to 1981 (191).

SPECIES AND NUMBERS

Unknown

OTHER INFORMATION

Charoon Youngprapakorn of Samutprakan Crocodile Farm, Thailand reports having given assistance in the establishment of this farm (211). 
No commercial crocodilian breeding operations exist in Colombia, but there are two (formerly three) breeding centres for conservation or scientific purposes.

NAME OF OPERATION

Estacion de Biologia Tropical

Roberto Franco station

Villavicencio (Meta)

Apartado aéreo 22-61.

Operated by: INDERENA (Instituto de Recursos Naturales y del

Ambiente).

SPECIES AND NUMBERS

Crocodylus intermedius: two pairs (127).

Caiman crocodilus: 17 animals.

Paleosuchus palpebrosus: 12 animals.

BREEDING

Paleosuchus trigonatus: 5 animals.

C. crocodilus and P. palpebrosus have both bred several times at the station.

OTHER INEORMATION

The operation is an outstation of the National University, in Bogota, and carries out studies on the biology of crocodiles and turtles, with the aim of applying the information gained to conservation (128).

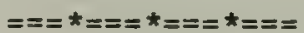

NAME OF OPERATION

Los Cocos Breeding Station

Salamanca Island.

Operated by: INDERENA (Instituto de Recursos Naturales y del Ambiente).

SPECIES AND NUMBERS

Crocodylus acutus: 30 were reported to be maintained in 1980, 3 adults and 27 juveniles.

BREEDING

A breeding programme exists but up to 1980 had yet to achieve results. Eggs were laid in 1977 and 1978 but did not hatch (126).

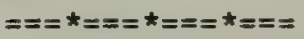

NAME OP OPERATION

Cienaga Grande Management Station

Cienaga Grande.

Ambiente).

Operated by: INDERENA (Instituto de Recursos Naturales $y$ del

SPECIES AND NUMBERS

Caiman crocodilus fuscus

OTHER INFORMATION

Apparently only a few animals were kept at the station, which does not seem to be operating any longer. Of these some were stolen by local residents who sold them in Baranquilla, and the rest escaped during a flood (126). 


\section{COSTA RICA}

A commercial farm was being set up in the country in 1984 by a commercial company acting in conjunction with the Ministry of Agriculture. They had a stock of about 100 young animals, probably Caiman crocodilus, ranging from hatchlings to about three years old (153). 
There are no commercial crocodile farms in cuba but there is one large conservation-orientated operation at Laguna del Tesoro. A second conservation operation was established more recently at Tasajera, also in the zapata swamp. There are reports that some skins are sold from the farms.

NAME OF OPERATION

Centro de Cria de Cocodrilos

Laguna del Tesoro (Treasure Lagoon)

$Z$ apata swamp.

Operated by: Ministerio de la Industria Pesquera,

Direccion Ramal de Acuicultura.

DATE OF ESTABLISHMENT

1965 (92)

SPECIES AND NUMBERS

The total adult population was about 1000 in 1981 of which about 808 were Crocodylus rhombifer, 58 were Crocodylus acutus and 158 hybrids of these two species.

There were also about 5000 immature crocodiles of a similar species composition; these were made up of about 2500 from the 1981 hatch, 1500 produced during 1979 and 1980, and 1000 of older age groups (64)

PRODUCTION AND TRADE

Some of the large crocodiles have been slaughtered for hides (185), meat is sold locally and skins are exported (92). Considerable quantities of skins of unknown source are said to be exported from Cuba, especially to the German Democratic Republic (188).

SOURCE OP ANIMALS

The local populations of both species were moved to the operation to ensure their survival (185). Over the years almost $36000 \mathrm{C}$. rhombifer have reportedly been removed from wild populations and placed on experimental farms (130).

BREEDING

The two species have inter-bred in the past, but recently attempts have been made to keep the two stocks apart. The breeding (and presumably mating) seasons of the two species show little overlap which must reduce inter-breeding. Female hybrids are certainly fertile but the fertility of the male hybrids is unknown (64). Most eggs are laid on islands in the lagoons. Up to 25 eggs are collected from each nest and hatched in incubators (92). Some eggs are hatched in semi-natural conditions, buried in soil in a hatching enclosure (64). When the young are born they are removed to rearing pens before being put back into the lagoons. It is reported that the mortality of the $\underline{c}$. acutus young is much higher than that for C. rhombifer (135).

In 1981 eggs were collected from 600 nests. The mean clutch sizes were $C$. rhombifer 35 eggs, C. acutus 48 eggs, and hybrids 42 eggs. The hatching rate for all groups was similar and averaged 468 . The total number of young hatched was about 10000 (64).

BUSBANDRY

The farm covers an area of 15 ha and includes breeding pens, rearing pens, brooding pens, infirmary pens and administrative buildings. It has a workforce of 23 people. Most of the adult crocodiles are kept in a large ( 8 ha) breeding pen, but there is also a smaller breeding pen containing only $c$. rhombifer, selected as having the best specific characteristics (64). 
The animals are fed fish and scraps from a cattle slaughter-house and some rotted fruit (92). Small crocodiles are fed on fish $10-12 \mathrm{~cm}$ long three to five times a week; adults are fed twice a week. Freezer facilities are not available, the food being obtained locally and brought by truck as required (64). The young grow at about $1.5 \mathrm{ft}$ $(0.46 \mathrm{~m})$ a year, and reach adult size at about 7 years (92). They are kept in small lagoons with natural vegetation and are separated by age class to prevent the older animals from killing the young (135). Mortality is high during the first year of life but decreases thereafter (64).

RESEARCH AND PUBLICATIONS

There are no details of published research but many of the details quoted by Ottenwalder (135) are translated from:

Anon (1979). Cienaga de Zapata, paraiso al Sur: reservorio de flora Y fauna. Prisma Latinoamericano, July.

Garrido, 0. (1980). Los vertebrados terrestres de la Peninsula de zapata. Poeyana, 203: 1-49.

OTHER INRORMATION

The operation was set up to preserve the two species involved. Some of the $C$. rhombifer were moved to the Tasajera operation to breed pure individuals of the species (185). It is hoped to release pure-bred $\mathrm{C}$. rhombifer into Zapata Swamp (92).

Up to 200 tourists a day, mostly from Havana, visit the farm but no entrance charge is made (64).

$=\approx * *=* *=\approx *=\approx=$

NAME OP OPERATION

Tasajera

southwest of Zapata

Habana Province.

Operated by: Ministerio de la Industria Pesquera,

Direccion Ramal de Acuicultura.

DATE OP ESTABLISHMENT

Thought to be 1978 or 1979 (135).

SPECIES AND NUMBERS

Crocodylus rhombifer

PRODUCTION AND TRADE

The operation seems to be conservation-orientated. SOURCE OP ANIMALS

The animals were transferred from the farm at Laguna del Tesoro in order to breed pure captive $C$. rhombifer as the number of crocodiles produced at Laguna del Tesoro that were pure-bred was not thought to be sufficient $(185)$. 


\section{ETHIOPIA}

In 1981 a proposal was put forward for a crocodile farm, expected to grow from pilot phase to producing about 20000 skins a year within five years. Farming of fish, rabbits, rodents and fowl as food was considered. No further progress is known (43).

In 1983 the FAO provided assistance to a crocodile management programme. Funds were made available in 1984 for a Government pilot rearing station at Arba Minch near Lake Abaya. Fishery wastes and associated culled wildlife were to be used as food. Construction was under way in 1984, and it was hoped to increase production to 1500 skins a year in five years (43).

The farm covered an area of 3 ha and was surrounded by a fence $2 \mathrm{~m}$ high. It included a block of 50 ponds for hatchlings, and incubation facilities were also planned. Suitable nesting sites around Lake Abaya had been surveyed and it was hoped to collect the first batch of eggs for hatching on the farm in 1985 (58). 
It was reported in 1985 that experiments were to be conducted to test the feasibility of rearing crocodilians in provence using thermal effluent from a C.E.A. nuclear power station at Bollène, near Avignon. It was planned to conduct growth trials using "young crocodiles" (Caiman crocodilus? Melanosuchus niger?) imported from "Guyana" (French Guiana?). If these proved successful financial backers would need to be sought. The nearby tanneries of Annonay or Saint-Chamond were mentioned as being potentially interested ( 99 ). 


\section{GREECE}

Plans for a crocodile farm were reported in 1984 but recent information suggests that progress may have been delayed.

NAME OF OPERATION

Crocodos

Rhodian Crocodile Farm Ltd

Tris Area P.O. Box 331.85100

Rhodes.

The farm is to be situated at Kalavarda on the north coast of Rhodes and is a subsidiary of:

Clal Crocodile Farms Ltd

5 Druyanov street

Tel-aviv 63143.

DATE OF ESTABLISHMENT

Building was expected to start in 1984 but was delayed by bureaucratic problems. The first crocodiles were to be obtained in 1985 (153).

SPECIES AND NUMBERS

Crocodylus niloticus: about 150. PRODUCTION AND TRADE

The operation is intended primarily as a tourist attraction but skins will also be produced. (153).

SOURCE OP ANIMALS

All the animals were to be purchased from farms in zimbabwe in March 1985 (153). -

BREEDING

Breeding is planned when the stock is mature (153).

HUSBANDRY

Breeding stock are to be kept in outdoor display ponds but there are also to be some indoor ponds for rearing juveniles (153).

PINANCES

The operation intends to derive a large part of its income from tourists (153).

OTHER INFORMATION

The Ministry of Agriculture in Greece is co-operating in the establishment of this farm. 
General Information

The Government of India initiated a crocodile Breeding and Management Project as a conservation measure in 1975 with preliminary surveys being undertaken in 1974. The project operated until 1982 on advice from a UN/FAO Chief Technical Adviser with finance from UNDP (89).

The project involves collecting eggs from the wild, incubating them and rearing the hatchlings up to a size at which they can be released. Thirty-four crocodile rehabilitation stations have been established throughout the country comprising 13 specially created sanctuaries and a further 21 National Parks or other sanctuaries, covering a total area of $20399 \mathrm{~km}^{2}$. Crocodiles have been released in the majority of these areas. The numbers of each species handled under the scheme are given below (167):

\begin{tabular}{lccr}
\hline & $\begin{array}{c}\text { Eggs } \\
\text { handled }\end{array}$ & $\begin{array}{c}\text { Hatchlings } \\
\text { handled }\end{array}$ & $\begin{array}{c}\text { Animals } \\
\text { released }\end{array}$ \\
\hline Gavialis gangeticus & 6000 & 4000 & 1185 \\
Crocodylus porosus & 2500 & 1700 & 408 \\
Crocodylus palustris & 9000 & 6000 & 502 \\
\hline
\end{tabular}

Captive rearing or breeding schemes for crocodilians in India (167). X - species reared; A - breeding attempted; B - breeding successful

G. gangeticus C. porosus C. palustris

\begin{tabular}{|c|c|c|c|c|}
\hline Port Blair & Andaman Nicobar & - & $x$ & • \\
\hline Hyderabad & Andhra Pradesh & $\mathrm{x}$ & $\mathrm{x}$ & B \\
\hline Nagarjunasagar & $"$ & - & - & $x$ \\
\hline Mutta & Bihar & - & - & A \\
\hline Sasan Gir & Gujarat & - & - & $\mathrm{x}$ \\
\hline Banarghatta & Karnataka & A & - & B \\
\hline Neyyar & Kerala & - & - & $x$ \\
\hline Peruvannamuzhy & $*$ & - & - & $\mathrm{x}$ \\
\hline Deori & Madhya Pradesh & $\mathrm{x}$ & - & • \\
\hline Tadoba & Maharastra & - & - & A \\
\hline Dangamal & Orissa & - & B & - \\
\hline Nandankanan & 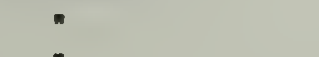 & B & $A$ & B \\
\hline Ramatirtha & $"$ & - & - & B \\
\hline Tikerpada & $"$ & $x$ & - & B \\
\hline Kota & Rajasthan & $x$ & - & $x$ \\
\hline Amaravati & Tamilnadu & - & - & B \\
\hline Hogemnakal & 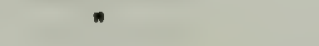 & - & - & A \\
\hline Masinagudi & . & - & - & $x$ \\
\hline Madras & " & - & - & B \\
\hline Sathanur & " & - & - & B \\
\hline Katerniyaghat & Uttar Pradesh & $x$ & • & $A$ \\
\hline Kukrail & " & $x$ & . & A \\
\hline Bhagabatpur & West Bengal & • & B & • \\
\hline
\end{tabular}


More than 2000 eggs a year are collected for captive hatching by different state crocodile projects in India (89).

Captive rearing or breeding is being attempted at the locations listed below. Sites at which breeding has been attempted or successful are indicated. All of these schemes have been established since 1975. Captive breeding has also been achieved at five zoos and at the Madras Snake Park (167).

The rehabilitation schemes which have taken place within India have shown the potential of $c$. palustris as a subject for commercial utilization through farming or free-range sustained-yield exploitation (89). Following clearance from the Indian Bureau of Wildlife, a proposal was under consideration in 1984 for the experimental farming of C. palustris under closed-cycle conditions (167).

\section{Selected operations:}

\section{NAME OF OPERATION}

Amaravathi Crocodile Farm.

One of two main crocodile rearing centres (the other being Sathanur Reservoir) of the Tamilnadu Forest Department is at Amaravathi Reservoir, where Crocodylus palustris has been bred since 1983. SPECIES AND NUMBERS

Crocodylus palustris: about 600 reported $(70)$. PRODUCTION AND TRADE

Currently an experimental commercial operation to assess the feasibility of crocodile farming: it is hoped to commence production by 1990 (165).

\section{SOURCE OF ANIMALS}

Eggs are collected from Dhuvanam area of the Amaravathi Reservoir and taken to the farm to be hatched and reared. 15 nests are known in the wild in this area (70).

BREEDING

The farm has a breeding stock of 8 adults, which produced 5 nests in 1983. This stock is from the $1975 / 76$ wild-caught females. A low hatching percentage of $20-30 z$ is thought to be due to the intense heat in the hatchery $(70)$.

\section{HUSBANDRY}

The crocodiles are reared in concrete ponds which are being altered as they are thought to be too shallow. Water comes chiefly from a percolation well.

\section{PINANCES}

The farm was set up by the Tamilnadu Forest Department.

\section{OTHER INFORMATION}

After the success of the Rehabilitation Programme of Gavialis gangeticus and Crocodylus palustris, the Government of India decided to make a start with crocodile farming (131). The current operation is a pilot project investigating the commercial viability of crocodile farming in India. It is likely that several of the other Indian states will also set up farming and ranching operations once the wild population is established (197).

A proposed crocodile farm site of the Tamilnadu Forest Department is in Kilikudi Village, near Kallanai about $10 \mathrm{~km}$ from Tiruchirapalli. In 1974 the proposed area was described as follows: "at the proposed 
site is a three to four acre $(1.2-1.6 \mathrm{ha})$ pond, $6-10 \mathrm{~m}$ deep. About 20 crocodiles are believed to be naturally resident and breeding there, where they are protected and regularly fed by the Forest Dept. At night, they move between the pond and the Grand Anicut of the coleroon River, about $300 \mathrm{~m}$ away." (193)

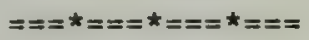

NAME OF OPERATION

The Madras Crocodile Bank Trust

Vadanemmeli Village, Perur P.O.

Mahabalipuram Road

Chingleput District

Madras-603 104 .

Managed by: Romulus Whitaker.

DATE OP ESTABLISAMENT

In 1975 an Indian Government/FAO/UNDP project was started, to rehabilitate wild populations of crocodiles. Madras Crocodile Bank Trust was set up as an offshoot of Madras Snake Park (a non-government trust) in 1975, with help from the World Wildlife Fund (197). The Crocodile Bank Trust is situated about $40 \mathrm{~km}$ South of the Madras Snake Park. In 1977 the Trustees agreed to set up the Madras Crocodile Bank as an international bank to establish a gene pool of every species of crocodilian. This received the approval of the IUCN/SSC Crocodilian Specialist Group in 1978 (202).

SPECIES AND NUMBERS

Crocodylus palustris: 8 breeding females, 1100 immature (201)

Crocodylus porosus: 1 breeding female, 48 immature (202)

Caiman crocodilus: 4 breeding females, 109 immature (202)

Gavialis gangeticus

Alligator mississippiensis

\section{PRODUCTION AND TRADE}

This is a conservation operation. 465 C. palustris were supplied to State rehabilitation programmes from 1976-1982 (202).

BREEDING

The following breeding success has been achieved at the Madras Crocodile Bank (202):

\begin{tabular}{lcccc} 
& $\begin{array}{c}\text { Years } \\
\text { nested }\end{array}$ & $\begin{array}{c}\text { No. of } \\
\text { females }\end{array}$ & $\begin{array}{c}\text { No. of eggs } \\
\text { produced }\end{array}$ & $\begin{array}{c}\text { Hatching } \\
\text { percentage }\end{array}$ \\
c. palustris & 7 & 8 & 2433 & 63 \\
\hline C. porosus & 2 & 1 & 106 & 46 \\
\hline c. crocodilus & 3 & 4 & 341 & 33 \\
\hline
\end{tabular}

The C. palustris have been reported to produce two clutches of eggs within one breeding season, the size and hatching success of the second clutch being similar to the first (199).

RINANCES

Income from the entry fees of 25000 visitors a month makes the Crocodile Bank financially self-sufficient. Crocodiles supplied to State projects and National Parks are paid for on the basis of their feeding and maintenance costs alone, at no profit (197). 


\section{INDONESIA}

General Information

Crocodiles have been exploited in Irian Jaya for some time and there is evidence that the wild populations have declined through over-hunting (142). At the fifth meeting of the conference of the Parties to CITES in 1985 a proposal was approved whereby the Indonesian population of Crocodylus porosus was transferred from Appendix I to Appendix II with the imposition of a maximum annual quota of 2000 skins and provision that they should all be tagged.

A survey was carried out in late 1984 which ascertained that considerable hunting was still occurring in spite of the ban which was supposed to have been in force since 1980 and that several thousand skins annually were being illegally exported from Irian Jaya. Many local crocodile populations had been wiped out and most of the others were severely depleted. Crocodylus porosus was particularly severely affected as it occurs in the larger, more accessible waterways than Crocodylus novaeguineae (204).

It is the expressed aim of the Government to institute a farming programe similar to that of Papua New Guinea (61), and a scheme was initiated in 1980 when legislation protecting the wild population was enacted. The project is being carried out under the title 'Crocodile conservation and industry development in Irian Jaya', involving a number of consultants, which started with a survey in October 1984 for an initial period of four months (143). The purpose is to promote the conservation of crocodiles by utilizing them as a resource to benefit the indigenous communities. The primary aim is to establish the most suitable areas to set up collecting farms, determine the numbers of crocodiles that will need to be collected, investigate the economics, and recommend appropriate legislation. It is proposed that skin exporters will only be able to obtain live crocodiles from collection farms, and that strict quotas will be set for the exploitation (34).

Farming was started in 1976, but the Government stopped further expansion until the ability of wild stocks to support a farming industry had been assessed. The system relies on the capture of young crocodiles from the wild, and rearing them until they are large enough to slaughter. In 1980 there were 4000-5000 crocodiles on farms in Irian Jaya. The farms were reported to be of varying size and were, on the whole, poorly managed and uneconomic. Most of the farms started because the Government obliged all companies wanting to export skins, to operate a crocodile farm. Therefore economics have not been of prime importance, but rather the farms have been established to comply with Government regulations. However, by 1980 it had been realised that farms would have to be more efficient as the wild population would not support indiscriminate hunting indefinitely. At that time it was found that management was poor on the existing farms, that pen design and general health of the crocodiles was only fair and that there was a great need for management training and advice (121).

The next survey, conducted in late 1984, reported a total population of 4051 crocodiles on 12 major farms in Irian Jaya but with no indication of the species composition. The survey concluded that the survival of the crocodile population depended on the establishment of an adequately controlled ranching programme. Initially it was 
recommended that the scheme should be confined to $c$. novaeguineae, as the $C$. porosus populations were too severely depleted to sustain any exploitation. Three large rearing farms should be established in Merauke, Jayapura and Sorong, each to house 5000-10 000 crocodiles. A scheme to buy 7000-10 000 young $C$. novaeguineae annually from villagers and take them to about 25 collecting farms should be established, and the villagers should be given shares in the farms to provide them with a long-term interest. Resources of trash fish available were assessed to be adequate for such a scheme (101).

Everywhere in the Mamberamo delta and along the river up to Kasonoweja (Pioniersbivak) local people were reported in 1979 to keep crocodiles in often very dirty enclosures fenced by corrugated iron (112). Scattered small-scale enclosures were also mentioned in 1984 (101). Skins of crocodiles reared by the villagers are often bought by the local government employees who then sell them to the large trading companies. The main centres for crocodile hunting in the area are Merauke, Jayapura, and Serui on the island of Japen (112).

Most of the skins exported go to singapore; in 1980 the average skin size exported was 15.5 inches $(38 \mathrm{~cm})$ belly width; of these skins 108 were Crocodylus porosus and 908 Crocodylus novaeguineae (121).

The prices quoted in Paris in 1984 for salted skins were US\$9 and US\$12 per inch belly width (US\$3.54 and US\$4.72 $\mathrm{cm}^{-1}$ ) for $\underline{C}$. novaeguineae and $c$. porosus respectively. It was estimated that the sale of by-products could increase the value of each crocodile by a further $30 \%(101)$.

According to official figures in the proposal submitted to the fifth CITES Meeting (32) the annual totals of skins exported from 1980 to 1983 were $4953,200,360$ and 1180 . There are indications that the true level of exports was considerably higher than this (101). It has been reported that rearing farms are "obliged to release to the wild habitat at least 10 of of their rearing products, and they are obliged to develop themselves fully into breeding farms" (32). There is no evidence that any deliberate releases have taken place and no breeding taking place on farms in Irian Jaya (143), although limited breeding has been reported in Java. The survey in 1984 concluded that none of the farms in Irian Jaya was commercially viable, and that the most of the skins exported were from the wild (101).

A list of 15 registered crocodile farming companies was supplied by the Director General of Forest Protection and Nature Conservation in 1984, 12 in Irian Jaya and 3 in Sumatra (157):

1. C.V. Kiman Raya, J1. Raya Mandala 14, Merauke, Irian Jaya.

2. P.T. Wana Nusantara, J1. Raya Mandala, Merauke, Irian Jaya.

3. P.T. Buma Kumawa, J1. Izak Telussa 16, Fakfak, Irian Jaya.

4. C.V. Doom, Jl. Trikora, Sorong, Irian Jaya.

5. C.V. Sinar Asahan, J1. Sam Ratulangi, Jayapura, Irian Jaya.

6. C.V. Skyline Raya, J1. Pembangunan 11, Jayapura, Irian Jaya.

7. C.V. Sinar Moy, J1. Burung Kakatua 5071 Remu, Sorong, Irian Jaya.

8. C.V. Bintang Diai, J1. Kalibaru Apo 37, Jayapura, Irian Jaya.

9. C.V. Jaya Abadi, J1. Raya Mandala, Merauke, Irian Jaya.

10. P.T. Jaya Agung, J1. Raya Mandala, Merauke, Irian Jaya.

11. C.V. Manturi, Bintuni, Manokwari, Irian Jaya.

12. Fa. Giat Maju, J1. Pemuda Nabire, Irian Jaya.

13. Alian Ruswan, J1. Ampelas 1-A, Medan, Sumatera Utara.

14. C.V. Stock Borsuma, J1. Kartini 4-A, Palembang, sumatera Selatan. 
15. C.V. Reptil Corporation, J1. H.Z. Arifin Dalam No. 116-A, Medan, Sumatera Utara.

It was reported that three of the registered farms (presumably numbers 1, 2 and 4 ) in Irian Jaya were not operational in 1984, but other farms were reported to be in existence (101).

The total number of crocodile farms in Indonesia is thus thought to be in excess of 17 farms, comprising something over 12 in Irian Jaya, three in Sumatra, one in Java, one in the Mentawai Islands and possibly a few in Kalimantan. 


\section{Irian Jaya}

The following operations were described in surveys of Irian Jaya conducted in 1980 and 1984, the species involved were $\underline{C}$. porosus and/or c. novaequineae. There is some confusion of identifying the individual farms and relating them to those listed above.

\section{NAME OF OPERATION}

Operated by: P.T. Buma Kumawa.

J1. Izak Telussa 16, Fakfak, Irian Jaya (157).

Located at: Sarmi, Jayapura District (101) (see no. 3 in list?)

P.T. Buma Kumawa was given an address in Fakfak by the Director Gereral of Forest Protection and Nature Conservation (157), but the company was reported to be operating a farm in the Jayapura district in 1984 (101). DATE OP ESTABLISHMENT

There was no record of this farm in 1980 (121). SPECIES AND NUMBERS

60 animals were kept in 1984 (101).

$=\approx=*=\approx *=ニ=*=ニ=$

\section{NAME OF OPERATION}

Operated by: C.V. Sinar Asahan.

J1. Sam Ratulangi, Jayapura, Irian Jaya.

Located at: Sentani. (see no. 5 in list)

(C.V. Sinar Asahan formerly operated a second farm in the Jayapura district, see below).

DATE OP ESTABLISHMENT

The farm was reported to be operating in 1978 (101).

SPECIES AND NUMBERS

In 1978 the stock was reported to be 1165 (101). 350 animals were kept in 1980 (121), but only 260 in 1984 (101). TRADE

Between November 1976 and November 1977 C.V. Sinar Asahan (an export firm) sold 15828 inches $(40293 \mathrm{~cm})$ of hide to singapore (112). It is not known whether this was from wild-caught animals or from farms. HUSBANDRY

The crocodiles were kept in 8 ponds of concrete and iron with concrete feeding platforms. The water was changed by natural flow into the swamp. Management was reported to be fair and the stock looked healthy in 1980, but there were problems with theft of crocodiles (121).

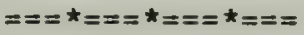

NAME OF OPERATION

Operated by: C.V. Skyline Raya.

J1. Pembangunan 11, Jayapura, Irian Jaya.

Located at: Jayapura. (see no. 6 in list)

SPECIES AND NUMBERS

800 animals were kept in 1980 (121). By 1984 the stock had increased to $2000(101)$. It was hoped that the operation would eventually expand to 10000 animals (121). 


\section{TRADE} HUSBANDRY

It was claimed in 1980 that the farm did not buy skins (121).

The diet consists of chicken offal from an adjoining poultry production operation. The farm was reported to have a good layout with concrete and brick pens. Breeding was planned and the level of management was described as "fair" in 1980 (121).

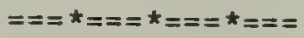

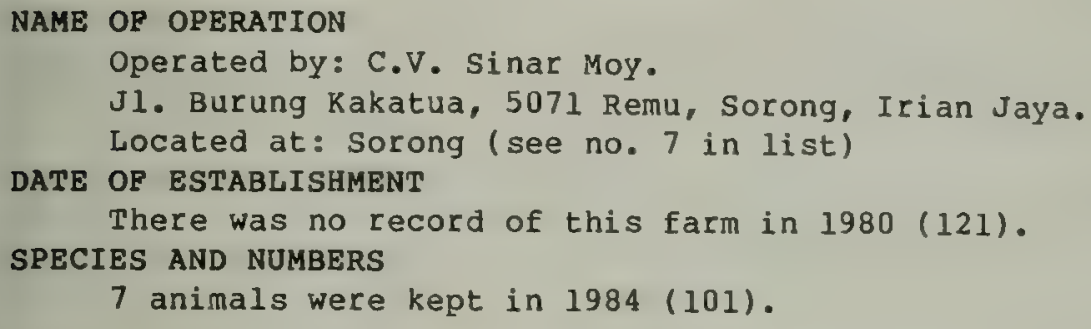

In 1978 the stock was reported to be 352 (101). 417 animals were kept in 1980, $708 \mathrm{C}$. novaeguineae and $30 \% \mathrm{C}$. porosus (121). In 1984 the stock was not inspected, but was estimated to be about 400 (101). HUSBANDRY

In 1980 the farm was reported to be poorly managed and to have experienced thefts (121). 
NAME OF OPERATION

Operated by: C.V. Jaya Agung.

J1. Raya Mandala, Merauke, P.O. Box 223, Irian Jaya.

Located at: Kimaam (101), (Kumbis, P. Dolok (121)?) Merauke. (see no. 10 in list)

DATE OR ESTABLISHMENT

Established in 1976 (121), although it has been reported that this farm had been authorised by the Government to breed crocodiles as early as 1974 (42).

SPECIES AND NUMBERS

In. 1978 the stock was reported to be 200 (101). 300 animals were kept in 1980, $40 \% \mathrm{C}$. novaeguineae and $60 \% \mathrm{C}$. porosus (121). In 1984 the stock was not inspected, but was estimated to be about 600 (101). HUSBANDRY

The crocodiles were kept in well designed pens of earth and concrete/brick in 1980; management was fair (121).

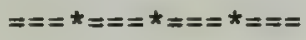

\section{NAME OP OPERATION}

Operated by: Fa. Giat Maju.

J1. Pemuda Nabire, Irian Jaya.

Located at: Nabire, Paniai District. (see no. 12 in list)

DATE OF ESTABLISHMENT

There was no record of this farm in 1980 (121).

SPECIES AND NUMBERS

19 animals were kept in 1984 (101).

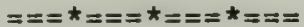

\section{NAME OP OPERATION}

Operated by: P.T. Pengkaran Rakyat,

Located at: Sikari, Jayapura. Irian Jaya.

This farm was apparently not registered with the Director General of Forest Protection and Nature Conservation in 1984 (157).

DATE OF ESTABLISHMENT

There was no record of this farm in 1980 (121).

SPECIES AND NUMBERS $400(101)$.

In 1984 the stock was not inspected, but was estimated to be about

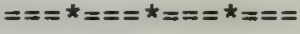

\section{NAME OF OPERATION}

Operated by: C.V. Nikmat.

Located at: Merauke. Irian Jaya.

This farm was apparently not registered with the Director General of Forest Protection and Nature Conservation in 1984 (157).

DATE OF ESTABLISHMENT

There was no record of this farm in 1980 (121). SPECIES AND NUMBERS

In 1984 the stock was reported to be 187 (101). 


\section{NAME OP OPERATION}

Operated by: Fa. Modan Baru,

Located at: Sorong. Irian Jaya.

This farm was apparently not registered with the Director General of Forest Protection and Nature Conservation in 1984 (157).

DATE OF ESTABLISHMENT

There was no record of this farm in 1980 (121).

SPECIES AND NUMBERS

In 1984 the stock was reported to be 15 (101).

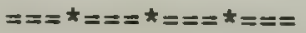

NAME OF OPERATION

Operated by: Toko Sulawesi,

Located at: Kaimana, Fak Fak. Irian Jaya.

This farm was apparently not registered with the Director General of Forest Protection and Nature Conservation in 1984 (157).

DATE OF ESTABLISHMENT

There was no record of this farm in 1980 (121).

SPECIES AND NUMBERS

In 1984 the stock was reported to be 25 (101).

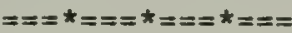

NAME OP OPERATION

Operated by: C.V. Siola Jaya.

Located at: Jayapura. Irian Jaya.

SPECIES AND NUMBERS

200 crocodiles were kept in 1980, and the farm hoped eventually to house 2000 animals (121). There are no indications that this farm was continuing to operate in 1984 (101).

HUSBANDRY

The animals were kept in small concrete pens. Management level was reported to be poor and the crocodiles were unhealthy (121).

$=\approx *=ニ * *==*===$

NAME OF OPERATION

Operated by: C.V. Siola Jaya.

Located at: Mudie. Irian Jaya.

DATE OF ESTABLISHMENT

1976.

SPECIES AND NUMBERS

2000 crocodiles were kept in 1980. The farm hoped to expand to 5000 animals (121). There are no indications that this farm was continuing to operate in 1984 (101).

HUSBANDRY

The ponds were constructed of plastic covered by iron wood. The farm employed 10 permanent labourers and 140 contract hunters for skins and live crocodiles (121). 


\section{Indonesia}

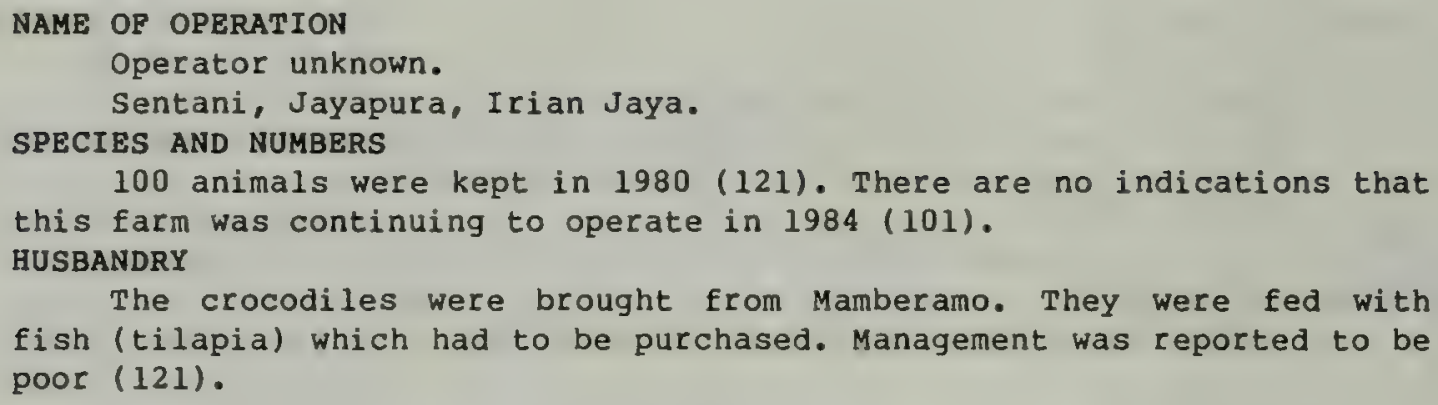

The crocodiles were brought from Mamberamo. They were fed with fish (tilapia) which had to be purchased. Management was reported to be poor (121).

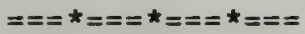

NAME OP OPERATION

Operated by: C.V. Sinar Asahan.

Jayapura, Irian Jaya.

This is the second of two farms operated by C.V. Sinar Asahan reported in 1980. The company was reported (101) as operating only one farm in 1984, at Sentani, Jayapura (see above).

SPECIES AND NUMBERS

250 animals were kept in 1980, mainly C. novaeguineae (121). There are no indications that this farm was continuing to operate in 1984 (101).

PRODUCTION AND TRADE

Skins. The farm bought young crocodiles at 5- to 8-inch (13- to $20-\mathrm{cm}$ ) belly width and slaughtered them at a belly width of about 12 inches $(30 \mathrm{~cm})$ 18-24 months later (121).

SOURCE OF ANIMALS

These came from local wild populations. In october 1977 the farm received 200 young crocodiles from the Mamberamo area (112). HUSBANDRY

The pens were made of brick and concrete, management level was described as fair. The diet consisted of fish which was purchased locally (121).

$$
==ニ *=ニ *=ニ ニ *=ニ=
$$

\section{NAME OF OPERATION}

Operated by: a resident army officer.

Kimam, Irian Jaya.

SPECIES AND NUMBERS

25 animals were kept in 1980 (121). There are no indications that this farm was continuing to operate in 1984 (101).

HUSBANDRY

The crocodiles were kept in a 'back-yard pond', the water being changed only when it rained. Management was reported to be poor. Food was purchased from local villagers (121). 


\section{Indonesia}

NAME OF OPERATION

Operated by: C.V. Bangun Jaya.

Merauke, Irian Jaya.

SPECIES AND NUMBERS

50 animals were kept in 1980. The owner hoped to expand to 500-600 animals (121). There are no indications that this farm was continuing to operate in 1984 (101).

TRADE

It was claimed in 1980 that the farm did not buy skins (121). HUSBANDRY

The farm had concrete-walled pens capable of accommodating 1000 crocodiles but claimed to have been limited by the Government. Management was reported to be fair (121).

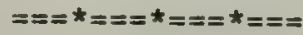

\section{NAME OF OPERATION}

Operated by: C.V. Sumber Usaha.

Merauke, Irian Jaya.

DATE OF ESTABLISHMENT

The farm was described as "only new" in 1980 (121).

SPECIES AND NUMBERS

230 animals were kept in 1980, 50\% C. novaeguineae and 508 C. porosus (121). There are no indications that this farm was continuing to operate in 1984 (101).

HUSBANDRY

The crocodiles were kept in brick pens. The water supply from a well was "insufficient". Mortality rate was 5-7\%, management reported to be fair (121).

$==* *==*==* *===$

\section{NAME OF OPERATION}

Operated by: Roger Fidelis.

Sorong, Irian Jaya.

SPECIES AND NUMBERS

85 animals were kept in 1980 (121). There are no indications that this farm was continuing to operate in 1984 (101).

SOURCE OP ANIMALS

The crocodiles were collected from the Vogelkop area. HUSBANDRY

The farm was built to accommodate 600 crocodiles. The diet consisted of chicken offal and fish. Management was reported to be good and the crocodiles healthy. Water was supplied by tidal ebb and flow (121).

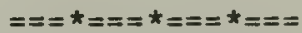

\section{NAME OF OPERATION}

Operated by: P.T. Pabnuamakmur.

Sorong, Irian Jaya.

\section{SPECIES AND NUMBERS}

115 animals were kept in 1980, mainly $C$. porosus (121). There are no indications that this farm was continuing to operate in 1984 (101). 
Indonesia

HUSBANDRY

The operation was run in conjunction with a poultry and pig farm. There were 12 pens with space for 600 animals. Management was reported to be good and the crocodiles healthy (121).

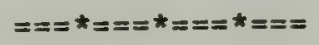

\section{NAME OF OPERATION}

Operated by: Aken Tjong Min Liang,

Merauke, Irian Jaya.

SPECIBS AND NUMBERS

30 animals were kept in 1980 (121). There are no indications that this farm was continuing to operate in 1984 (101).

HUSBANDRY

The operation was not thought to have potential owing to the expense of purchasing food and water. Management was reported to be poor but the crocodiles were healthy (121). 
There are a few rearing farms in the vicinity of Jakarta, which are dependent on eggs and young taken from the wild. Very little breeding takes place on these farms (112).

Details of one farm at Yayasan were given in 1980 when it was reported that relocation was being considered (121). It is thought that this may now have been achieved and that the new farm is located at Pluit, North Jakarta. Details of both sites are given:

\section{NAME OP OPERATION \\ Jakarta Crocodile Farm \\ Yayasan, Jakarta, Java. \\ Operated by: Lukman Arifin. \\ DATE OP ESTABLISHMENT}

1959

SPECIES AND NUMBERS

In 1980 it was reported that 500-600 crocodiles were being held, including 120 Tomistoma schlegelii, some $\mathrm{C}$. porosus and $\mathrm{C}$. siamensis (121).

PRODUCTION AND TRADE

The operation derived income from tourists and from sale of live animals. No details of skin production were obtained (121).

SOURCE OF ANIMALS

908 of the animals were obtained from sumatra and Kalimantan. They were purchased at $40=70 \mathrm{~cm}$ length but the smallest of these usually died (121).

BREEDING

In 1978 large numbers of eggs were laid but few hatched and none survived two weeks. In 1979 the eggs laid were transferred to artificial nests but only 15 hatched; several of the hatchlings died and the remainder were being kept in an open plastic bucket and were looking week. They had deformities indicative of incorrect nest temperatures. It was reported that the owner's knowledge of crocodile biology was not sufficient to succeed with crocodile propagation. It was thought that the farm would have to be relocated in order to succeed with a breeding programme, as the existing facilities were inadequate (121).

HUSBANDRY

The ponds were of insufficient depth and much fighting occurred. The nesting boxes were too small and contained little nesting material. Breeding $C$. porosus and $C$. siamensis were being kept together under crowded conditions (121).

PINANCES

The farm was open to the public and claimed to have an attendance of 4000 a week (121).

OTHER INPORMATION

The stock was thought to have great potential for breeding and production, however both the management and conditions in 1980 were unsuitable (121). 
It was reported that a new crocodile farm had been created at Pluit, North Jakarta (24). It is not clear whether this replaced the farm at Yayasan, but this is thought to be the case as it was also run by Mr Arifin:

NAME OP OPERATION

? Crocodile Farm

Pluit, North Jakarta, Java. Operated by: Mr Arifin.

DATE OP ESTABLISHMENT

The farm was planned by and received approval from the Governor in $1976(24)$.

SPECIES AND NUMBERS

In 1984 there were reported to be 500 crocodiles at the farm, species unknown (24).

PRODUCTION AND TRADE

The operation derives income from tourists and provides displays, such as wrestling with crocodiles and snakes. Food is also sold, snake sate, obon made from snakes and monitor lizards, and various medicinal preparations for the treatment of skin diseases and irritations (24). BREEDING HUSBANDRY

The farm was reported to be used for crocodile breeding (24).

The farm has a total area of $2 \mathrm{ha}$, and was reported to be extremely overcrowded. 9 crocodiles had already died of disease in 1984. The water in the ponds was said to be "brackish", and funds were not available to rectify this (24).

\section{PINANCES}

The new farm was reported to be receiving fewer visitors than the old farm and it was suggested that the whole farm needed upgrading if it were to provide a worthwhile recreational facility (24).

The farm was opened with the assistance of the Jakarta administration as part of the Pluit Environmental Development Project. OTHER INPORMATION

The farm also keeps other species, including snakes, which are used in the displays (24). 
The Director General of Forest Protection and Nature Conservation listed three farms in sumatra (numbers $13-15$ in the list) in 1984 (157). Details were acquired of a farm near Medan, which probably corresponds with number 15.

\section{NAME OP OPERATION}

A crocodile farm is located at a village $12 \mathrm{~km}$ from Medan:

Desa Asam Kumbang

Kecamantan Pasar Lima

Medan

North Sumatra.

Managed by: Mr Lo Than Muk.

A breeding licence for three years was granted to C.V. Reptil Corporation, Medan, on behalf of the farm in 1981 by the Direktorat Jenderal Perlindungan Hutan dan Pelestarian Alam. Renewal of the licence was delayed in 1985 until further clarification of details of the farm was obtained (169).

DATE OP ESTABLISHMENT

The farm started in 1959 in Jalan Gurami, with 12 crocodiles, but when the stock increased to 200 the farm moved to a new, larger site (36).

SPECIES AND NUMBERS
Crocodylus porosus:
Tomistoma schlegéli :
1138 (including 311 females "in nature")
12 (169)

The farm was reported to have 200 breeding females in 1985 (36).

PRODUCTION AND TRADE

The farm is reported to sell skins (36).

SOURCE OF ANIMALS

No animals have been obtained from the wild since 1975, and all new stock is bred on the farm (169).

BREEDING

Breeding is reported to have first occurred in 1979 when 200 eggs were hatched. It is reported that the 200 breeding females now produce "a minimum of 6000 " hatchlings a year (36). These figures seem unlikely to be correct.

HUSBANDRY

The maximum hatching success is reported to be $80 \%$ (169).

The farm covers an area of 0.539 ha, comprising (169):

Earth pond for mature females

Cement pond for mature females

Cement pond for young

Earth breeding pond

Housing and other

$$
\begin{array}{r}
900 \mathrm{~m}^{2} \\
750 \mathrm{~m}^{2} \\
230 \mathrm{~m}^{2} \\
2437 \mathrm{~m}^{2} \\
1073 \mathrm{~m}^{2}
\end{array}
$$

Food is obtained from one shrimp enterprise, 20 poultry farms and C.V. Reptil Corporation in Medan (169).

PINANCES

The farm has been open to tourists since April 1983 (169). Entrance fees were Rp300 for adults and Rpl50 for children in 1985. 300-400 people visit the farm on sundays (36). 


\section{$\underline{\text { Ralimantan }}$}

When the wild population became too scarce to support hide hunting, owing to over-exploitation and habitat destruction, eggs and young were captured for rearing in farms in Kalimantan, Java and Singapore. A number of these farms were in operation in Kalimantan at Samarinda on the Mahakam River, and at Tanjung Redeb on the Berau River, and at Bandjarmasin. Most of these farms were closed by the mid-1970s because the growing rarity of the wild crocodiles made it difficult to secure the eggs and young needed (112).

\section{Mentawai Islands}

A rearing farm for eggs and young taken from the wild was reported at Sikakap on Pagai Island (112). 


\section{ISRAEL}

In 1985 there were two crocodilian farms in Israel, but one of the companies, which has crocodile-farming interests in several countries, intended establishing other farms in the country in the future.

\section{NAME OF OPERATION}

Alligator Farm

Hammat Gader Hot Springs

Hammat Gader

D.N. Rammat Hagolan 12480.

DATE OF ESTABLISHMENT

August 1981

SPECIES AND NUMBERS

Stock in 1983 (49):

Alligator mississippiensis:

Crocodylus niloticus suchus:

302

osteolaemus tetraspis osborni:

4

PRODUCTION AND TRADE

The operation in 1983 was run solely for tourists but it was intended that live sales to zoos and commercial operations would take place in the future.

SOURCE OF ANIMALS

In 1981120 A. mississippiensis were obtained from a farm in Florida. four 0 . tetraspis and four c. niloticus were subsequently obtained from the University of Tel-Aviv (48).

BREEDING

The initial stōck of alligators is reported to have come from farm-bred alligators making the stock born on this farm, in effect, second generation captive-bred. However $A$. mississippiensis has not yet been bred through two generations on the farm. The farm incubator has a capacity of over 300 eggs (49).

The numbers of A. mississippiensis bred in 1982/83 were as follows:

$\begin{array}{rrrr}\frac{\text { Year }}{1982} & \frac{\text { Number bred }}{4} & \frac{\text { Number survived } 30 \text { days }}{4} \\ 1983 & 184 & 180 \quad \text { (49) }\end{array}$

The animals are kept in one large pond $\left(4000 \mathrm{~m}^{2}\right)$ divided into three sections, five small concrete pools (each $1.5 \mathrm{~m}^{3}$ ) and a hothouse with seven pools. The large pond is surrounded by $5000 \mathrm{~m}^{2}$ of grass and contains a natural swampy area. It has a constant flow of spring water at $28^{\circ} \mathrm{C}$. Even on the coldest nights the temperature in the large pool was not found to fall below $20^{\circ} \mathrm{C}$ and in the small pools it was in excess of $25^{\circ} \mathrm{C}$. This is sufficient to prevent the onset of winter dormancy and the animals were found to be eating 60-70\% of their summer diet during the winter. The animals are fed $50 \%$ poultry, 308 beef and $208 \mathrm{fish}$, the proportions varying with availability, at about 88 of body weight each week (48).

PINANCES

The operation is self-financing as part of a large tourist complex. 


\section{RESEARCH AND PUBLICATIONS}

Results were presented at the 6 th working meeting of the IUCN/SSC Crocodilian specialist group (See 48 ).

Research is carried out by the farm staff, in co-operation with the University of Tel-Aviv. 10 of of the eggs are given to the University for research, after which the hatchlings are returned to the farm. OTHER INPORMATION

The farm is situated in a region of warm springs in the vicinity of the Yarmuk river. There are plans to expand the population of alligators and eventually to sell excess stock of one-year-olds, to commercial operations. The operators would also like to increase their range of species and to attempt breeding of other species (49).

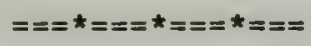

NAME OF OPERATION

Clal Crocodile Farms Ltd

5 Druyanov street

Tel-Aviv 63143.

General Manager: Shlomi Ranot.

The farm is situated at Kibbutz Ganshmuel, $60 \mathrm{~km}$ North of Tel-Aviv and $5 \mathrm{~km}$ from the coast.

DATE OP ESTABLISHMENT

The first crocodiles were obtained in November 1984. SPECIES AND NUMBERS

Stock in 1984 (153):

Crocodylus niloticus:

5 adult males

40 immature males ( $2 \mathrm{~m}, 5$ yr-old)

160 immature females $(2 \mathrm{~m}, 5 \mathrm{yr}$-old)

\section{PRODUCTION AND TRADE}

The operation intends to produce skins eventually but also admits tourists. It is hoped to supply breeding stock which may be used by other farms to be set up in Israel by the company. The animals at present on the farm should breed in 1986, in which case the first skin production would be in 1989 (153).

SOURCE OF ANIMALS

All the animals were purchased from farms in $\mathrm{zimbabwe}$ in November 1984. It was hoped to obtain some additional hatchlings from the same source (153).

\section{BREEDING}

FINANCES

The breeding stock should be mature in 1986 (153).

The operation intends to derive a large part of its income from tourists (153).

OTHER INEORMATION

Clal Crocodile Farms Ltd owns other crocodile farms in Kenya and Greece, and intends setting up a total of 7 farms in other countries, including the Caribbean and Israel. 
Only one crocodilian farm is reported to have operated in Italy, but it is now thought to have closed down.

\section{NAME OF OPERATION}

Compagnia Internazional Allevamento Animali Esotici (C.I.A.A.E.)

Commune di Presicce

nr. Brindisi

Provincia Di Leceo.

DATE OF ESTABLISHMENT

1980. No recent information regarding this farm has been received and it is presumed to be no longer in existence.

SPECIES AND NUMBERS

Claimed to be "Caiman latirostris originating in Colombia" (147), however this species does not occur in Colombia (89) and no captive sources are known; so the animals must either have originated elsewhere or be of a different species, probably Caiman crocodilus.

There were 406 surviving caiman in January 1981 (147),

PRODUCTION AND TRADE

Skins were reported to be provided to the Italian leather industry. SOURCE OP ANIMALS

The entire stock originated in Colombia, supplied by a reptile dealer named Simon Daza, of Baranquilla. In December 19803000 animals were imported to Italy for the farm, and a further 1500 were due to arrive on 20 April, 1981 from the same source (147).

BREEDING

None.

HUSBANDRY

The farm was surveyed by A.C. Pooley in January 1981. The 3000 caiman which were to form the initial farm stock left colombia during the Colombian summer period all packed in one crate, suitable for only 1000 animals at the most, and arrived in Italy during the Italian winter when temperatures were around $0^{\circ} \mathrm{C}$. About 1500 animals died before reaching the farm. Between the last week of December 1980, and the second week of February 1981 a further 1094 animals died, probably due to Salmonella poisoning and fungal disease. The remaining 406 animals were still being kept in poor conditions at the time the farm was surveyed and it was estimated that 100-150 were on the verge of death. It was suggested to the Managing Director of the firm, Senor Lili del Saudia, to postpone the further order of caiman from Colombia (147).

The animals were reportedly kept in ponds which were "overcrowded, unsanitary, stagnant, surrounded by faeces-laden sand, and with insufficient heating". They had been fed on a diet of fatty mince and were suffering from malnutrition (147).

\section{BINANCES}

The operation was privately financed, with backing from the Italian reptile leather industry (76). 
In 1980 a consultant was engaged by the firm PGU-Kronberg Unternehmensberatung GMB Kronberg, F.R. Germany, to advise on the potential for crocodile farming in the Ivory coast in connection with the German Wildlife Project. Interest centred on crocodylus niloticus and Crocodylus cataphractus. Surveys revealed severe depletion of crocodile populations which were not thought capable of sustaining commercial ranching schemes at that stage. It was recommended that a pilot scheme at Abidjan $Z 00$ be expanded to develop husbandry techniques for commercial farms in the future, and to supply crocodiles for restocking. In 1981 the zoo held 7 osteolaemus tetraspis, 4 Crocodylus niloticus and 3 Crocodylus cataphractus (52).

Nile crocodiles are also kept in a moat surrounding the presidential palace in yamoussoukro. It is not known whether any breeding has taken place there. 


\section{JAMAICA}

There is reported to be one crocodilian farm in Jamaica, primarily orientated towards tourists:

\section{NAME OF OPERATION}

Swamp Safari, situated about 20 miles East of Montego Bay.

The farm is owned by the Tourist Board of Jamaica but is held on a five-year lease by a commercial company, Cherokee Enterprises. DATE OP ESTABLISHMENT

About 1970

SPECIES AND NUMBERS

Crocodylus acutus: approximately 50 in 1984.

\section{BREEDING}

22 young were hatched in 1984.

OTHER INFORMATION

The farm is primarily a tourist attraction but commercial production is apparently under consideration (153). 


\section{JAPAN}

The Atagawa Tropical Garden and Alligator Farm, Shizuoka, Japan, is a long-established display farm holding a very wide variety of crocodilian species. It is situated in a area of thermal springs which are used to heat the crocodile ponds $(100)$. It acquired five crocodylus johnsoni from the Northern Territory of Australia in 1984 at which time its stock also included Crocodylus porosus and Gavialis gangeticus (27). Eight captive-born crocodylus moreletii, one of the few species missing from the collection, were supplied by the Atlanta zoological Park, USA, in 1984 (33). The farm caters purely for tourists and, so far as is known, does not engage in skin sales (100). 


\section{KENYA}

There are two crocodile farms in Kenya, both situated near Mombasa:

\section{NAME OF OPERATION}

Baobab Farm Limited

P.0. Box 90202

Mombasa.

Managing Director: R.D. Haller.

DATE OF ESTABLISHMENT

The farm is primarily concerned with arable crops, domestic stock and fish (tilapia) culture (91), as part of a rehabilitation project to reafforest a worked-out limestone quarry. In 1975 crocodile hatchlings were introduced as part of the ecosystem (43).

SPECIES AND NUMBERS

$$
\begin{aligned}
& \text { Crocodylus niloticus: } \quad 9 \text { adults } \\
& 600 \text { hatchlings in } 1984 \text { (43). }
\end{aligned}
$$

\section{PRODUCTION AND TRADE}

In 1977 the Government of Kenya passed a law forbidding the sale of most wild animal products in the country. This has prevented the farm from operating commercially. Crocodile farming is being developed for future production when allowed. This would probably be based on skin production (116).

SOURCE OF ANIMALS

The original stock were wild-caught as hatchlings in 1975. Of these, 9 adults survived in 1984. Since 1982, eggs have also been collected from the wild (43):

$$
\begin{aligned}
& 211 \text { in } 1982, \\
& 685 \text { in } 1983 \text {, and } \\
& 60 \text { in } 1984 \text { (43). }
\end{aligned}
$$

\section{HUSBANDRY}

The crocodiles are kept in tanks of water supplied by run-off from the fish tanks. The pens range from 20 to $600 \mathrm{~m}^{2}$ with natural or artificial ponds and are surrounded by concrete walls or diamond-mesh fences.

Tilapia of non-commercial size which are discarded by the fish farm, or carcases from the livestock section are provided as food (43). BREEDING

The captive-reared adults have bred since 1982; 9 young were hatched in 1982 and 13 in 1983 but all failed to survive. 25 hatched in 1984 and two of these survived for 30 days. It was hoped to supplement the breeding stock with some wild-caught nuisance animals (43).

The following success with the hatching of wild-collected eggs has been reported $(43)$ :

$\begin{array}{llll} & \begin{array}{l}\text { Eggs } \\ \text { collected }\end{array} & \begin{array}{l}\text { Eggs } \\ \text { hatched }\end{array} & \begin{array}{l}\text { Survived } \\ 30 \text { days }\end{array} \\ 1982 & 211 & 198 & 189 \\ 1983 & 685 & 542 & 505 \\ 1984 & 60 & 56 & 52\end{array}$

\section{PINANCES}

The company is a subsidiary of Bamburi Portland Cement Co. Ltd and all research is funded by a grant from the parent company. 
Some income is obtained from tourism as part of a larger Nature Trail complex which was opened in 1983 (43).

RESEARCH AND PUBLICATIONS

Research is conducted by R.D. Haller \& J.D. Balarin on feeding rates, grading, pathology, pen design, breeding and social behaviour as well as census surveys of the wild population (43).

Balarin, J.D. (1982). The suitability of farm-reared fish (Tilapia spp.) as a food for juvenile crocodiles (Crocodylus niloticus). Proceedings of the IUCN/SSC Crocodilian Specialist Group Meetinge Victoria Falls. OTHER INFORMATION

The initial three-year pilot phase of the farm was completed in 1984. Permission was being sought to be allowed to trade commercially.

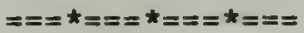

NAME OF OPERATION

Mamba Village, Kenya Crocodile Farm Ltd

PO Box 85723

Mombasa.

Organiser: Clal Crocodile Farms, Israel.

The crocodile farm is located in a 20 -acre (8.1-ha) disused quarry at Nyali, north of Mombasa.

DATE OF ESTABLISHMENT

Probably late 1983 (170).

The first phase of construction, comprising a tourist centre and aquascape of $1-2$ ha of ponds was completed in 1984 when the venture was opened to tourists (43).

SPECIES AND NUMBERS

C. niloticus, target stock of 20000 by 1986 (28).

The original stock of 650 in 1983 (28) has been supplemented by hatchlings in 1984 believed to amount to some 250-300 (43).

PRODUCTION AND TRADE

Full production, once achieved, should be 3000 skins a year with a value of about US\$70 000 (28).

The venture is also intended to cater for tourists (170). SOURCE OF ANIMALS

The original stock of 650 crocodiles was trapped along the Tana River in a three-month exercise (28). Crocodiles were reported to be being trapped from Garsen to Wenje in 1984 (124). The company holds a licence from the Ministry of Environment and Natural Resources to collect eggs, and has a monopoly in this respect (153).

HUSBANDRY

The animals are kept in concrete ponds, surrounded by wire mesh. Some adult animals were present in 1984 in addition to 400-500 juveniles of about $40 \mathrm{~cm}$ length (170). BREEDING

About 250-300 eggs are believed to have hatched in 1984 (43). 


\section{MADAGASCAR}

Only one crocodile farm is known to exist in Madagascar. This was the first farm to have been registered with the CITES Secretariat as a recognised captive-breeding operation.

NAME OP OPERATION

Elévage de crocodiles d'"Antsobolo"

Antsobolo

Ampanotokana Ambohidratrimo

Madagascar.

Director: M. Charles A. De Lanessan.

This farm has also been referred to as the "Mahitsy crocodile Farm".

DATE OF ESTABLISHMENT

1974.

The farm was set up in 1969 and started commercial production in

\section{SPECIES AND NUMBERS}

Crocodylus niloticus In April 1983 the farm held a total of 454 crocodiles divided by size as follows:-

over $2.5 \mathrm{~m} \quad 5$

$1.5-2.0 \mathrm{~m} \quad 52$

$1.0-1.5 \mathrm{~m} \quad 116$

$0.7-1.0 \mathrm{~m} \quad 124$

Less than $0.7 \mathrm{~m} 157$

PRODUCTION AND TRADE

Crocodiles are killed at about 3.5 years of age. About half the skins are tanned in Madagascar for use in the manufacture of goods. The remainder are used for taxidermy. None is reported to be exported (14), however the Madagascar CITES annual reports list the export of 4,20 and 29 skins of captive-bred C. niloticus for the years 1981,1982 and 1983 respectively. The small quantities involved suggest that these may have been trade samples. (164).

In 1985 live crocodiles were supplied to a new farm in Mauritius

\section{SOURCE OF ANIMALS}

The original stock was taken from the wild in the form of young animals less than one year old. These have been raised to form a captive breeding stock. In 1980 the capture of wild animals ceased $(50)$. BREEDING

It took about 10 years to produce the first captive-bred generation in 1980 (72). About one hundred juveniles are now hatched on the farm each year and it is hoped that this figure will improve as the breeding stock continues to mature (50).

Breeding since 1980 :

$\begin{array}{rrll}1980 & 39 & \text { from } 1 \text { female } \\ 1981 & 109 & \text { from } 8 \text { females } \\ 1982 & 76 & \text { from } 2 \text { females }\end{array}$

(72)

\section{HUSBANDRY}

Total area $1300 \mathrm{~m}^{2}$. This includes $700 \mathrm{~m}^{2}$ of ponds, and $600 \mathrm{~m}^{2}$ of open space divided into 8 enclosed areas of pond and open land (72).

Gravid females are separated from the rest and the eggs are collected. They are then put in another pen, with sand banks, to hatch (14). 


\section{Madagascar}

The hatchlings are fed on frogs and insects. Dog meat, which is readily available locally, is the main food for adults. Feeding has been reduced from three times a week to twice a week to reduce sickness and diarrhoea (14).

Water supply is from a permanent creek. The temperature is low owing to the high altitude, and so the water is allowed to flow over an area of flat concrete to warm it up, apparently by as much as $10^{\circ} \mathrm{C}$. During the winter the crocodiles hibernate in tunnels in the earth side of each pen for up to four months (14).

FINANCES

The operation is self-financing from the sale of skins (72). RESEARCH AND PUBLICATIONS

General research into improvement of the operation is carried out by the Director, Charles De Lanessan.

OTHER INFORMATION

National legislation forbids the export of skins unless they are Erom captive-bred animals (72). 
A proposal submitted to CITES in 1985 suggested that controlled hunting of Crocodylus niloticus in Malawi was preferable to a ranching scheme, however one pilot project was reported to be in existence $(30)$. This crocodile farm was started at Mangochi in 1981, but it has not so far obtained a licence to trade (43).

Mr Khalid Hassan was reported to be trapping crocodiles in 1984 on the Shire River for a proposed farm on Lake Malawi (183). 
There are believed to be 7 crocodile farms in Peninsular Malaysia, one in sabah and about three or four in sarawak. The native crocodylus porosus population is thought to be essentially extinct in the peninsula (112).

\section{Peninsular Malaysia}

The Government Department of Wildlife and National Parks supplied the following information about farms keeping crocodylus porosus; stocks of Crocodylus porosus held in 1984 are indicated. The first of these farms is the only one which may be undertaking breeding. Tomistoma schlegelii are not used commercially.

Tulin Enterprise

Jalan Pondok Upeh

Balik Pulau

pulau Pinang

Chuah Teong Chew

No: 30, Main Road

Simpang Taiping

Perak, West Malaysia

Kok Cheong Be

e Kuck Aik Leng

No: 16 Jalan Menggala

Matang, Taiping

Perak

Lean Kim Huat

30 Jalan Telok Rertang

Matang, Taiping

Perak

Hasan Basri b. Ismail

Bt. 8, Jebong Kiri

Matang, Taiping

Perak

Chong Kew Meng

Bagan Sg. Pulai

Sabak Bernam

Selangor

Ang Kok Leong

222, Kg. Baru

Jenjarum, Kuala Langat

selangor
264

181

54

19 


\section{$\underline{\text { Sabah }}$}

Eggs and young of $C$. porosus are taken from the wild for rearing in Sabah and Singapore hide farms, but the wild populations are so reduced that this trade has decreased in recent years (112). One rearing farm (see below), located just outside sandakan, Sabah has been rearing $C$. porosus for export since about 1970 (14). Following a survey of crocodiles in sabah in 1984, whitaker (200) recommended the establishment of an exploitation project including a Government research farm at sepilok, encouragement of private investment to develop large commercial farms, and initiation of an egg-collection project involving local people.

NAME OF OPERATION

Chai mei Hwa Crocodile Farms

P.O. Box 633

Sandakan

Sabah.

Owner: Chai Yau Look.

DATE OF ESTABLISHMENT

About 1970

SPECIES AND NUMBERS

C. porosus: 1035 individuals in 1984 (7).

These included 6 adults and a further 40 which would mature within the next few years $(200)$.

PRODUCTION AND TRADE

The crocodiles are reared for their skins and for meat which is marketed locally (7).

Since 1978 skins have been sold to a dealer, Mr Tan, for export to Singapore and Japan. Meat is also exported to Hong Kong (14).

A total of about 2000 skins have been cropped in the last 15 years, 308 of which were males and 708 females. Since the Government ban on collection of animals from the wild, all cropping has ceased and the stock is being saved for breeding (200).

SOURCE OF ANIMALS (7).

The original crocodiles were wild-caught but this is now illegal BREEDING

In 1984 the crocodiles had not yet bred, but a breeding programme had been initiated with a 30-m diameter pen containing four females and two males (200).

HUSBANDRY

The crocodiles are kept in an enclosure with an area of $1000 \mathrm{ft}^{2}$ (93 $\mathrm{m}^{2}$ ) containing a natural pond. The pool has a maximum depth of $15 \mathrm{ft}(4.6 \mathrm{~m})$ and is $30-40 \mathrm{ft}(9-12 \mathrm{~m})$ in diameter. In 1978 an unknown epidemic killed over 200 crocodiles, mostly juveniles (14).

OTHER INFORMATION

The owner informed Mr Andau that young crocodiles are smuggled in from Kalimantan, Indonesia (7). 


\section{Sarawak}

Rearing farms exist which raise wild $\mathrm{C}$. porosus hatchlings. About 10 Tomistoma schlegelii are also thought to be present in the farms, the skins of which will probably eventually be sent to singapore (89).

There are reported to be three or four farms run by families in the area (117). Two operations are described:

NAME OF OPERATION

? Crocodile Farm

Pedada Road

Sarawak.

Operated by the Wong family.

SPECIES AND NUMBERS

C. porosus: over 100 are kept (117).

PRODUCTION AND TRADE

The crocodiles are raised for skins and meat. Skins are sold to a merchant in singapore to be made into handbags belts and shoes. Meat is sold locally, and is considered a delicacy in the area (117).

SOURCE OF ANIMALS

Animals are obtained from local fishermen (117).

HUSBANDRY

The crocodiles are raised to a length of around $4 \mathrm{~m}$ on a diet of pig livers, intestines and chicken meat (117).

$===*=ニ \approx *=ニ=*===$

NAME OF OPERATION

Owner: "Johnson" Jong Joon Song

P.O. Box 670

Kuching

Sarawak.

SPECIES AND NUMBERS

C. porosus: 100 hatchlings and 600 "full-grown" animals (207). PRODUCTION AND TRADE

Skins are sold to Hong Kong and Europe.

SOURCE OF ANIMALS

It was hoped that increased breeding success in 1985 would obviate the need to purchase crocodiles (207).

HUSBANDRY

The main breeding pen is $100 \mathrm{ft}$ long $(30 \mathrm{~m})$ and contains 50 adults (200). The hatchlings are fed on prawns. There are at least three farmhands (207).

BREEDING

Breeding has been achieved since 1981, a total of 21 nests having been laid from 1980-83. In 19837 females laid eggs but only two clutches produced young. Considerable effort has been directed towards developing breeding and incubation techniques and careful records are kept of reproductive data $(200)$.

Initially the hatching success was low, in the region of 208 , but this increased to 858 in 1983 (207).

BINANCES

Annual expenditure is in the region of $M \$ 80000$ and the farm is still running at a loss (207). 


\section{MALI}

A private company named Mali Reptiles plans to operate a crocodile farm near Bamako, in Mali, involving Crocodylus niloticus but the farm had not reached commercial status in 1983. A small pilot-scale farm has been operated since 1979 with 34 C. niloticus captured from ségou. The crocodiles are held in ponds with feeding installations and provision for cleaning the water. Research carried out since 1980, with FAo co-operation, has shown the project to be viable. Projected production is between 1000 and 3000 skins by 1986. The farm is financed by a private grant of MF90 000000 put up by European partners (159). 


\section{MAORITIUS}

The first crocodile farm started operation in Mauritius in 1985.

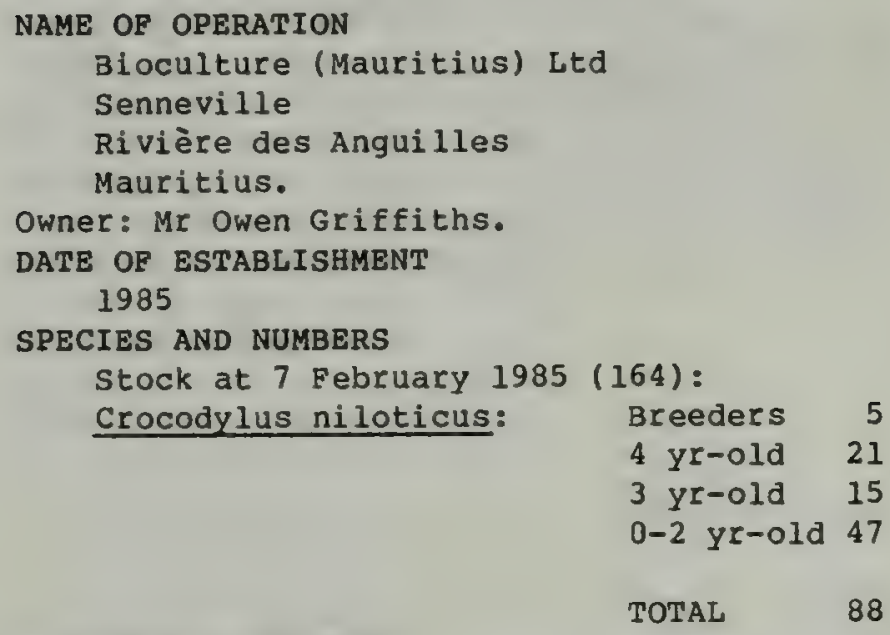

The original capacity of the farm in 1985 was for 250 animals, but it was hoped to increase this to 2000 (164). 


\section{MEXICO}

There are two Government departments in Mexico which are involved in the setting up of crocodilian farms, the secretaria de Pesca and the Secretaria de Desarrollo urbano y Ecologia (SEDUE). Between them they operate a total of seven breeding centres, with others planned. There is one farm operated by the Instituto Nacional de Investigaciones sobre Recursos Bioticos (INIREB) and two private farms. So far as is known, none of the farms is yet producing skins commercially, although this is clearly the ultimate intention. The secretaria de Pesca generally only involves itself in commercially related ventures.

A farm in Chiapas, the original funding for which was partially provided by the World Wildlife Fund, was forced to close because of oil pollution (118).

The Direccion General de Flora y Fauna Silvestre, a division of SEDUE, has also expressed an interest in starting a farm for Crocodylus acutus in Quintana Roo and for Crocodylus moreletii in Yucatan (118).

It was reported that the Mexican Government had established farms for Crocodylus moreletii in Veracruz (22), but Lazcano-Barrero (118) doubts that farms have ever existed in that state.

\section{NAME OF OPERATION}

Municipio de Acapetahua

Chiapas.

Operated by: Secretaria de Pesca.

SPECIES AND NUMBERS

Crocodylus moreletii (95).

In 1984 the farm was reported (118) as containing mostly Crocodylus moreletii and "a few caimans".

$$
==ニ *==*==+*==\text { = }
$$

NAME OP OPERATION

Municipio Temaxcal

Presa Miguel Aleman

Oaxaca.

Operated by: Secretaria de Pesca.

SPECIES AND NUMBERS

Crocodylus moreletii: only a few animals (95).

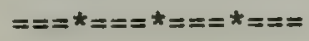

NAME OF OPERATION

Municipio del Centro

Ejido de Buenavista

Tabasco.

Operated by: Secretaria de Pesca.

SPECIES AND NUMBERS

Crocodylus moreletii: approximately 200 adults (95). 
NAME OF OPERATION

Lazaro Cardenas

Located in the estuary of the Rio Balsas, Michoacan.

Operated by: Secretaria de Pesca.

SPECIES AND NUMBERS

Believed to be Crocodylus acutus ( 95$)$.

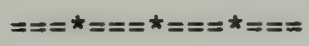

NAME OP OPERATION

Municipio Ciudad del Carmen

Ciudad del Carmen, "El Fenix"

Campeche.

Operated by: Secretaria de Desarrollo Urbano y Ecologia (SEDUE), Direccion General de Flora y Fauna Silvestre.

(This farm was recently transferred from the control of the secretaria de Pesca).

SPECIES AND NUMBERS

Crocodylus moreletii: approximately 200 adults (95).

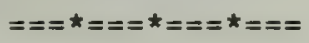

NAME OF OPERATION

Lagunas de Chacahua

Municipio Tututepec-Juquila

Oaxaca.

Operated by: Secretaria de Desarrollo Urbano y Ecologia (SEDUE), Direccion General de Flora y Fauna Silvestre.

SPECIES AND NUMBERS

Crocodylus moreletii: approximately 43 adults (95).

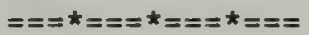

NAME OF OPERATION

Laguna Coyuca

Municipio Acapulco

Guerrero.

Believed to be operated by: Secretaria de Desarrollo Urbano y Ecologia (SEDUE), Direccion General de Flora y Fauna Silvestre.

DATE OF ESTABLISHMENT

The farm was reported to be "very recent" in June 1985 (95). SPECIES AND NUMBERS

Crocodylus moreletii (95).

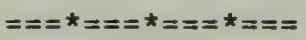

NAME OP OPERATION

Selva Lacadona

Chiapas.

Operated by: Instituto Nacional de Investigaciones Sobre Recursos Bioticos (INIREB).

DATE OF ESTABLISHMENT

The farm was reported to be "planned" in 1984 (118) and "operating" by June 1985 (95). 
SPECIES AND NUMBERS

Crocodylus moreletii and Crocodylus acutus ( 95 ). OTHER INFORMATION

The farm plans to breed crocodylus acutus and Crocodylus moreleti for commercial and conservation purposes, and will be managed by the rural people of the Lacadon Jungle. It will also serve as a tourist attraction and research centre. Funding is being supplied by INIREB, the Consejo Nacional de Ciencia y Tecnologia and the secretaria de Desarrollo Urbano y Ecologia (118).

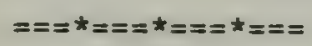

NAME OF OPERATION

Cuernavaca

Morelos.

The Earm is privately owned (95).

SPECIES AND NUMBERS

Crocodylus moreletii (95).

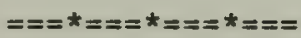

\section{NAME OP OPERATION}

Cancun

Quintana Roo.

The farm is privately owned, and is supported by the National Bank, SOMEX, who have made an initial investment of 60 million pesos (95).

DATE OP ESTABLISHMENT

The farm was reported to be "projected" in June 1985 (95).

SPECIES AND NUMBERS

Crocodylus moreletii: when operational, it is anticipated that this will be the largest crocodilian farm in Mexico (95).

\section{NAME OF OPERATION}

San Felipe Bacalar (?)

Quintana Roo.

Operated by: Centro de Investigaciones de Quintana Roo (CIQRO).

DATE OF ESTABLISHMENT

The farm was reported to be "projected" in June 1985 (95).

SPECIES AND NUMBERS

Crocodylus moreleti ( 95$)$.

$$
==ニ *=ニ *==* *===
$$

\section{NAME OR OPERATION}

Municipio Tecoman

Laguna de Alcozahue

Ejido Cofradia de Hidalgo

Colima.

Operated by: Secretaria de Desarrollo Urbano y Ecologia (SEDUE), Direccion General de Flora y Fauna Silvestre.

DATE OP ESTABLISHMENT

The farm was reported to be "in project" in June 1985 (95). 
Mexico

SPECIES AND NUMBERS

Crocodylus moreletii and Crocodylus acutus (95).

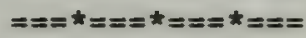

\section{NAME OP OPERATION}

Municipio de San Blas,

Laguna "El Tanque",

Ejido "La Palma",

Nayarit.

Operated by: Secretaria de Desarrollo Urbano y Ecologia (SEDUE), Direccion General de Flora y Fauna Silvestre.

DATE OP ESTABLISHMENT

The farm was reported to be "in project" in June 1985 (95). SPECIES AND NUMBERS

Crocodylus acutus ( 95 ). 


\section{MOZAMBIQUE}

Interest was expressed in developing a ranching programme for Crocodylus niloticus in Mozambique in 1981, and a pilot hatchery and hatchling pond was established at Marromeu. 7 nests were collected in December 1981, but the hatchery has potential for at least 30 nests (1500 eggs) (196). This farm was still operating on a small scale in 1984 (31).

A proposal was submitted to develop a ranch at Mungari Camp, Marromeu, utilizing waste meat and offal from mammal culling operations in the zambezi Wildife Utilization Area which totals $2.5 t$ a month, and should be sufficient for 2000 animals. A second ranch at Cubo village, Messingir, was proposed initially with 200 animals, but building up to 2000. This would utilize waste from the Tilapia and Clarias fishery in Messingir Reservoir (196). Captive-breeding operations for certain birds, reptiles and frogs were also being considered (175).

The ranching programme was still in the proposal phase in 1984, only one crocodile rearing station being reported at that time (31). The farm, EMOFAuNA Crocodile Farm, had 32 three-year-old crocodiles and had not collected any eggs in 1984. Previously the farm had held up to 800 crocodiles, and future expansion was still planned (176). 
There are no commercial crocodilian farms in Nepal, but there is a large breeding centre for gharial in the Royal Chitwan National Park.

NAME OP OPERATION

Gharial Breeding Farm

Royal Chitwan National Park

Kasara, Chitwan

Nepal.

Senior Warden: T.M. Maskey

DATE OF ESTABLISHMENT

1979

SPECIES AND NUMBERS

Gavialis gangeticus: 255 animals in 1983 (125). PRODUCTION AND TRADE

The Gharial Breeding Farm is not at present a commercial operation, however future commerce does not appear to have been ruled out.

Production of $G$. gangeticus for release to the wild can be summarised thus:

\begin{tabular}{lllll} 
Year & Place of release & & Age & Number \\
\cline { 5 - 6 } 1981 & Narayani River & 3 yrs & 50 \\
1982 & Narayani River & 3 yrs & 50 \\
1983 & Narayani River & 3 yrs & 50 \\
1983 & Koshi River & 3 yrs & 42
\end{tabular}

All of the animals released are tagged and some have been fitted with radio telemetry collars to allow monitoring (89). SOURCE OP ANIMALS

All of the animals have been obtained from the wild. The eggs are collected within Nepal.

Number of eggs obtained 1979-81

$\begin{array}{ll}1979 & 543 \\ 1980 & 350 \\ 1981 & 150\end{array}$

(125)

\section{BREEDING}

The animals do breed at the farm, however the main source of animals is from the hatching of wild-obtained eggs. A hatch rate of approximately 50 \% has been achieved.

\section{Number of eggs hatched and survival of hatchlings, 1979-81}

Year Number hatched Number survived

$1979 \quad 294$

$1980 \quad 187$

1981

64

\begin{tabular}{cc}
30 days & \\
\hline 200 & $68 \%$ \\
140 & 758 \\
30 & $46 \%$
\end{tabular}

HUSBANDRY

For the first year hatchlings are kept in the hatchling pools of size $2 \mathrm{~m} \times 2 \mathrm{~m} \times 0.5 \mathrm{~m}$. They are next moved to the yearling pool of size $4 \mathrm{~m} \times 4 \mathrm{~m} \times 1 \mathrm{~m}$. The pools are concrete and have a running water supply.

The animals are fed daily on locally available fish (125). 


\section{FINANCES}

The sponsors for the operation are His Majesty's Government of Nepal, the Frankfurt Zoological society and the Smithsonian Institution. RESEARCH AND PUBLICATIONS

Research is carried out by T.M. Maskey.

Some results of the operation have been published:

Maskey, T.M. and H.R. Mishra (1981). Conservation of Gharial in Nepal. In Majpuria, T.C. (Ed.) Wild is beautiful. pp. 185-196.

Maskey, T.M. (1982). Progress report on Gharial conservation project in Nepal. (Official memo).

Mishra, H.R. and T.M. Maskey (1982). Zuruck in die Flusse. Tier, Die Internationale Zeitschrift für Tier, Meuch und Natur, June. OTHER INPORMATION

This operation is at present purely conservation orientated (125).

It was estimated that there were a total of 250 captive $\mathbf{G}_{\text {. }}$ gangeticus and 10 captive C. palustris in Nepal in 1982 (197). 


\section{PARISTAN}

Interest in a crocodile conservation/management programne was expressed (201), and a Government plan to breed crocodiles and gharials in the Punjab and Sind was being considered for 1984 (163).

In $1979 \mathrm{Mr}$ s. Aftab Alam acting for IGUANA (2), a leather company of Pakistan, stated that the company intended to set up a commercial breeding programme involving Crocodylus palustris and Gavialis gangeticus, and that advice had been sought from WWF headquarters. The farm was planned to follow the pattern of Samutprakan, Thailand, but would not be started until a similar project, of greater priority to the company, involving Varanus griseus (desert monitor) had been established ( 3 ).

Address:

IGUANA

(Manufacturers of Reptile Skins and Leather Goods, Suede Wear and Footwear)

Noor Estate

Main Drigh Road

Karachi 8

PAKISTAN

The Ministry of Food, Agriculture and Co-operatives stated, in 1983, that IGUANA had not implemented their pian to breed Varanus and were unlikely to start breeding crocodiles (163).

The estimated total number of captive $c$. palustris in Pakistan in 1982 was $50(197)$. 


\section{PAPUA NEW GUINEA}

Most of the information in the Papua New Guinea section of this report was provided by Martin Hollands.

In the mid-1960s the Government of Papua New Guinea became concerned about the future of the crocodile industry in the country. In only two decades, unrestricted skin hunting had reduced the readily accessible populations to the extent that the harvests of both crocodylus porosus and Crocodylus novaeguineae had tailed off dramatically. Further indications about the state of the industry came from the size of skins exported; despite there being a marked preference for large skins the average size exported was down to below 8 inches (203 $\mathrm{mm}$ ) in belly width.

This concern led to the introduction of the crocodile Trade protection Act (1966), which set a maximum size on skins which could be traded, in an attempt to protect the remaining breeding stock. The Government's Wildlife Division also adopted a National Policy on Crocodile Farming, to try and substantially increase the potential revenue to the rural people from a sustained-yield management programme. This would be done by cropping at the readily-replaced hatchling level, with captive rearing of these to a commercially acceptable size. It was envisaged that the killing of wild crocodiles for their skins would slowly be replaced by the establishnent of hundreds of small village crocodile ranches.

Although the implementation of a ranching network, if somewhat different from that originally proposed, is progressing well, with nearly 30000 crocodiles now on ranches, it will be a number of years before ranched skins comprise the bulk of the trade of Papua New Guinea. However the harvesting of both skins and live crocodiles is now conducted in a controlled manner, with a monitoring programme to assess its impact. During the 1970 s and early $1980 \mathrm{~s}$ Papua New Guinea had been exporting a sustainable annual harvest of 15 000-35 000 $\mathrm{C}$. novaeguineae skins, and $7000-11000 \mathrm{C}$. porosus skins. This earns the country approximately US\$2 million a year.

Papua New Guinea now has a diverse, and somewhat confusing, range of crocodile ranching operations. These range from small village pens, which might never hold more than 25 animals, to large commercial ranches with up to 15000 which are still expanding. To appreciate the reasons for these, and to understand their respective roles it is necessary briefly to review the development of crocodile ranching in Papua New Guinea.

The original concept was that ranching would be on a village level. Virtually every village in crocodile areas would have a small, "bush material" pen, and feed a hundred or so crocodiles on fish. To encourage the development of these village operations the Government built a number of demonstration ranches in appropriate areas of the country. These would be used as models for village ranches, and as bases for extension work on crocodile husbandry, pen construction, skinning and skin treatment. Realizing the enormity of the task the Government requested, and received advice from the IUCN SSC Crocodile Specialist Group, and considerable assistance from the United Nations.

Between 1975 and 1979 considerable effort was put into the village ranching programme. At its paak there were approximately 200 village ranches operating, with a total stock of 8000 animals. However it soon became apparent that locating the rearing operations in the 
crocodile swamp areas had numerous problems, particularly ensuring a year round food supply, and siting the pens so that water is available in the dry season, without flooding in the wet season. It was realized that if village people were to be encouraged to keep crocodiles it would be necessary to develop a back-up rearing system, to which villagers could readily sell their animals when necessary. The opening of two large-scale commercial operations was therefore encouraged for development as the final rearing point for surplus village stock. These ranches were set up to utilise the large volume of cheap feed available as waste from the country's main poultry operations. Their location and available funding would allow many management and husbandry problems encountered in village operations to be overcome.

It was therefore essential to develop a live-purchase system capable of safely moving large numbers of small live crocodiles from villages to these commercial ranches. The basis of this network was to be the Government demonstration ranches, already built in the right places. These ranches took on the extra duties of acting as collection centres, and extensive patrols gave the village people the chance to sell stock they did not wish to rear themselves. By Government control of the price system it was ensured that prices of live animals were kept high enough to encourage hunters to spend their time trying to catch livestock instead of just skins. These Government ranches would continue buying stock until they had 300-400 crocodiles between about 50 and $90 \mathrm{~cm}$ total length. Representatives of one of the commercial ranches would then $f l y$ in a light aircraft to collect these. Specially designed cardboard tubes and boxes allowed the efficient loading of the animals, and their transport with extremely low mortality.

A number of private ranches also started selling direct to the commercial ranches. Some of these existed solely by catching and selling stock: others rear some stock and sell off any surplus. As feed is a greater constraint than crocodile availability, in virtually all places a "combined operations" ranch is the ideal. All live crocodiles brought in to these by outsiders can be purchased, hence helping the intended shift to ranching; those not too big to be kept on the available food are reared to culling size, any surplus is sold to the large commercial ranches. The Government is actively encouraging the development of these "midi-ranches" at abattoirs and fish plants throughout the country. The two already established at such localities are running very successfully; other operations in this category run well on locally-caught fish.

The details of the operations, included at the end of this section, only cover ranches involved in rearing; village ranches are not detailed, and operations which only sell live crocodiles are excluded. Skins both from ranches and the wild are sold through licensed exporters, and all shipments are checked and tagged by Government inspectors. Other crocodile products may only be sold by commercial ranches ( 97 ).

The total number of crocodile skins exported from Papua New Guinea since 1976 from both wild harvest and farms is shown in the following table. In $1983 \mathrm{farm}$ production was running at about 108 of the wild harvest but this seemed set to rise in the following two years. C. porosus comprised $18 \%$ of all wild-caught crocodiles but 298 of all skins exported from farms. This reflects the fact that it is 
preferentially kept on farms as it has a higher-value skin and it is easier to keep.

Crocodile skins exported from Papua New Guinea from 1976 onwards.

$\frac{\text { C. novaeguineae }}{\text { Wild }}$

$1976 \quad 23379$

$1977 \quad 26571$

$1978 \quad 30886$

197934836

$1980 \quad 27249$

$1981 \quad 14291$

$1982 \quad 23259$

$1983 \quad 13786$

1984

1985
C. porosus

Wild Farm

6257

6618

7157

7442

5717

3915

3923

3155

1304
460

731

Total

Wild Farm

29636

33189

38043

42278

32966

18206

27182

16941

830

540

1097

2401

1605

5600

4000

In 1982 France imported $63 \%$ of all the skins exported by Papua New Guinea, Japan imported 348 and Singapore 3\%. In 1983 the corresponding figures were France 378 , Japan 628 and Singapore 0.58 .

The Crocodile Trade (Protection) Ac 1974 established very firm controls over crocodile exploitation. Only citizens of Papua New Guinea may hunt or kill crocodiles, and licences are needed to trade in them. Traders must have lived in the country for at least two years and may only trade within a specified area. A separate licence is needed to export skins. Additional regulations were introduced in 1981 to control farms and the sizes of crocodiles exploited. No crocodile with a belly width greater than $510 \mathrm{~mm}$ may be traded or kept on farms, and crocodiles of less than $180 \mathrm{~mm}$ belly width may only be traded live for the purpose of stocking farms. Crocodile farms with more than 200 animals must acquire a licence, the conditions of which include completing 6-monthly stock returns and notifying the authorities of the outbreak of any disease (137).

The following sumnary details the numbers of live crocodiles taken onto ranches from the wild (97).

\begin{tabular}{|c|c|c|c|}
\hline Year & C. novaequineae & C. porosus & Total \\
\hline 1979 & 3958 & 974 & 4932 \\
\hline 1980 & 7669 & 2141 & 9810 \\
\hline 1981 & 8118 & 2178 & 10296 \\
\hline 1982 & 8602 & 2799 & 11401 \\
\hline 1983 & 2518 & 1091 & 4419 \\
\hline Total & 30865 & 9993 & 40858 \\
\hline
\end{tabular}




\section{Commercial ranches}

The large commercial ranches will be the final rearing station for the bulk of ranched crocodiles in Papua New Guinea. Rather than location being determined by crocodile distribution, the ranches are located where there is a plentiful supply of cheap food. The two already operating are in association with the countries two largest poultry operations, one in Port Moresby and one in Lae.

Details of pen design, husbandry, feed consumption, mortality and growth rates are in Melvin Bolton's "Crocodile Husbandry in Papua New Guinea", available from the Crocodile Project, Box 2141 Boroko, Papua New Guinea.

These ranches have now been granted permission to start breeding programmes, and it is probable that the considerably easier supervision of such large, centralised operations will allow them to be granted special dispensations on the size of skins they can market; they are already permitted to sell by-products, both domestically and for export (97).

\section{NAME OF OPERATION}

Mainland Reptiles

P.O. Box 196

Lae

Morobe Province.

Operated by: Mainland Holdings Pty. Ltd

DATE OP ESTABLISHMENT

Approved and established in August 1979.

SPECIES AND NUMBERS

$11250 \mathrm{C}$. novaeguineae

3750 C. porosus (97).

The total stock in March 1983 was 14000 animals (78).

By early 1984 the number had risen to 15000 (97).

PRODUCTION AND TRADE

Production is primarily aimed at skins but meat and other by-products which may have a commercial value are being examined (97). The meat cannot be sold locally as a Government licence is needed to buy or own any crocodile, or part thereof. Crocodile meat in a dried form is worth around $5 \$ 23 \mathrm{~kg}^{-1}$ in singapore, but as a $30-\mathrm{kg}$ crocodile yields only around $2 \mathrm{~kg}$ of dried meat this means crocodile meat is of little economic significance to the ranch. The managers are investigating the commercial possibilities of producing crocodile oil for the perfume industry (84).

Skins produced $(84, \# 85)$

$\underline{\text { YEAR }}$

1980

1981

1982

1984 *

\section{c. porosus}

0

318

459

1279

\section{C. novaeguineae}

15

250

804

6476
DESTINATIONS

$\begin{array}{ll}\text { Japan } & \text { France } \\ \text { Japan } & \text { France } \\ \text { Japan } & \text { France } \\ \text { Japan } & \text { France }\end{array}$

* estimated figures. These are artificially inflated as few animals were slaughtered in 1983 owing to the low price of skins (85). 


\section{SOURCE OF ANIMALS}

stock is mainly obtained from village type holding farms in the Sepik River area of north-east Papua New Guinea. These farms catch small crocodiles from the wild which are then transported by aeroplane to Lae. Mainland Holdings stated in 1983 that they prefer animals between $0.5 \mathrm{~m}$ and $1.0 \mathrm{~m}$ in length as these are easily transportable and have a lower mortality rate once introduced to the farm than smaller animals; 78 rather than 258. Prices paid for these animals are estimated on a sliding scale according to size, the highest price being paid for the $1.0-m$ animals. No extra is paid for animals over this size. In 1983 surplus stock was also taken from other farms (84).

Numbers of juveniles obtained from the wild, 1980 to 1982

\begin{tabular}{lcccc} 
YEAR & C. porosus & C. novaequineae & \multicolumn{1}{c}{ TOTAL } \\
1980 & 2469 & 5343 & 7812 & \\
1981 & 1159 & 4722 & 5881 & \\
1982 & 1813 & 3917 & $5730 \quad(84)$ \\
1983 & no details & & $1998(97)$
\end{tabular}

\section{BREEDING}

Breeding of $C$. porosus is intended. Breeding stock has been selected from animals reared on the farm and it is hoped to have 300 breeding females by the end of 1985. Breeding had not taken place by August $1983(84) . \bar{A}$ breeding licence was granted in 1983. The Government have also loaned the operation $28 \mathrm{C}$. porosus adults as breeding stock. Selected rearing stock of $c$. porosus will also be kept as breeders ( 97 ).

HUSBANDRY

The farm has at its disposal an area approximately $0.75 \mathrm{~km}^{2}$. stock is held in ponds and divided by size of animals. The animals are fed on chicken offal from the adjoining poultry farm. At present total food consumption by stock is about $10 \mathrm{t}$ a week. Breeding stock is to be kept in natural-type earth ponds with an initial male to female ratio of $1: 1$. The entire stock is counted once every year, each animal being measured and its condition examined (84). overall natural farm mortality averages 4.58 a year (97).

RINANCES

The crocodile farm is run in conjunction with a large commercial chicken farm. It is therefore not always possible to separate the costs of the two enterprises adequately; however it is considered to be a fully self-financing comercial venture.

RESEARCH AND PUBLICATIONS

A four-year study of growth and feeding trials is being carried out and the results are to be published.

Research on the growth and feeding of crocodiles has been carried out by Mark Rose (84). 
NAME OF OPERATION

Ilimo Farm

P.O. Box 1885 Boroko

Port Moresby

N.C.D.

DATE OF ESTABLISHMENT

1979

SPECIES AND NUMBERS

In 19792423 animals were held on the farm (2). By early 1984 this total was $5000: 3000$ C. novaeguineae

PRODUCTION AND TRADE

and 2000 C. porosus (97).

production is mainly of skins but also of meat, gall-bladders and penes. Production of other by-products is being considered (97).

SOURCE OF ANIMALS

All stock originates from wild-caught hatchlings (97) and has been almost entirely supplied, at Government-controlled prices, through the Government buying and redistribution schemes (115).

BREEDING

In 1983 a breeding licence was approved, and an initial breeding colony of 17 females and 7 males was loaned by the Government. Selected rearing stock will be kept for breeding (97).

HUSBANDRY

The farm is associated with the poultry industry and therefore has an assured supply of minced and chopped chicken offal from the local processing plant (97).

\section{"Midi-ranches"}

NAME OF OPERATION

Angoram Crocodile Farm

Angoram, East Sepik

Government of Papua New Guinea.

Previously a National Government demonstration, farm now operated by the East Sepik Provincial Government (97).

DATE OF ESTABLISHMENT

1979

SPECIES AND NUMBERS

350 C. novaeguineae

150 C. porosus (97).

PRODUCTION AND TRADE

A small number of skins are produced, the farm mainly sells live animals to the commercial farms (97).

SOURCE OP ANIMALS

All animals are obtained from the wild (97):

$\underline{\text { YEAR }}$

$$
\text { C. novaeguineae C. porosus }
$$

1981

$$
2161
$$

406

1982

599

153

HUSBANDRY

The crocodiles are fed on fish which is purchased locally (97). 


\section{NAME OF OPERATION}

Boboa Crocodile Farm

Boboa, Lake Murray

Western Province.

Previously a National Government demonstration farm, now run commercially by the provincial Government. It is proposed that the farm be handed over to the local council when proved commercially viable (97).

DATE OF ESTABLISHMENT

1968

SPECIES AND NUMBERS

C. novaeguineae and $C$. porosus

PRODUCTION AND TRADE

The farm sells approximately 250 skins a year, and some livestock to the commercial farms (97).

SOURCE OR ANIMALS

All animals are obtained from the wild (97):

YEAR $\quad$ C. novaeguineae $\quad$. porosus

$1981 \quad 950 \quad 27$

$1982 \quad 583 \quad 12$

HUSBANDRY

The diet consists of locally-caught fish (97).

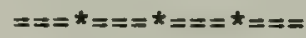

NAME OP OPERATION

Baimuru Crocodile Farm

c/o Fish Plant

Baimuru

Gulf Province.

DATE OR ESTABLISHMENT

1981

SPECIES AND NUMBERS

C. novaeguineae and $C$. porosus

PRODUCTION AND TRADE

The farm started production in 1984 of approximately 200 skins a year. Livestock is sold to the commercial farms (97).

SOURCE OF ANIMALS

All animals are obtained from the wild (97):

$\underline{\text { YEAR }}$

C. novaeguineae c. porosus

1982

127

302

HUSBANDRY

The farm is part of a fish processing plant (97). OTHER INPORMATION

Crocodiles on the farm have shown extremely high growth rates (97). 
Papua New Guinea

NAME OF OPERATION

Kikori Crocodile Farm

Kikori

Gulf Province.

Previously a National Government demonstration farm, now run commercially by the provincial Government.

DATE OF ESTABLISHMENT

1977

SPECIES AND NUMBERS

C. novaeguineae and $C$. porosus

PRODUCTION AND TRADE

The farm produces 100 - 200 skins a year. Livestock is sold to the commercial farms (97).

SOURCE OF ANIMALS

All animals are obtained from the wild (97):

YEAR

C. novaeguineae c. porosus

1981

1982

163

599

97

177

HUSBANDRY

Food consists of locally-caught fish and waste from a small fish plant (97).

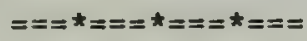

NAME OF OPERATION

Maningulai Import/Export

P.O. Box 46

Angoram

East Sepik.

DATE OF ESTABLISHMENT

1981

SPECIES AND NUMBERS

Approximately $1400 \mathrm{C}$. novaeguineae

Approximately 600 C. porosus (97)

PRODUCTION AND TRADE

The farm will produce skins and sell livestock (97). SOURCE OF ANIMALS

All animals are obtained from the wild (97):

$\underline{\text { YEAR }}$

c. novaeguineae c. porosus

1982

2232

616

HUSBANDRY

Diet consists of locally-bought fish. The operators are one of Papua New Guinea's main exporters of wild skins (97).

NAME OF OPERATION

Micro Enterprises

P.O. Box 995

Madang 


\section{DATE OF ESTABLISHMENT}

1980

SPECIES AND NUMBERS

Approximately $800 \mathrm{C}$. novaeguineae

Approximately 200 C. porosus (97)

PRODUCTION AND TRADE (97).

The farm produces skins and sells livestock to the commercial farms SOURCE OF ANIMALS

All animals are obtained from the wild (97):

YEAR

1982

\section{C. porosus}

113

\section{HUSBANDRY}

Food is obtained from a poultry operation. The company also deals in wild-caught skins (97).

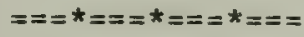

NAME OF OPERATION

Moitaka Crocodile Farm

Department of National Parks

P.O. Box 6601, Bokoko

N.C.D.

The operation was a Government demonstration farm but is currently run by the Department of National Parks as an educational/public display facility and for research by the Crocodile Management Project (97).

DATE OF ESTABLISHMENT

Early $1970 \mathrm{~s}$

SPECIES AND NUMBERS

C. novaeguineae - adults and $C$. porosus - adults.

In 1979 a total of 1150 crocodiles were held on the farm (194). PRODUCTION AND TRADE

The farm produced skins until 1982. There is no longer any commercial production from the farm ( 97 ).

SOURCE OR ANIMALS

All stock was originally wild-caught. There is no input of animals now ( 97$)$.

BREEDING

Both C. novaeguineae and $c$. porosus were bred and reared at the farm experimentally with the aim of improving rearing standards at the village level (194).

OTHER INPORMATION

A number of $C$. porosus reared at Moitaka were used for re-stocking depleted wild stocks in Gulf Province. By January 1981, 43 C. porosus from Moitaka had been released in Gulf Province for this purpose (59). 
NAME OP OPERATION

Pagwi Crocodile Farm

Pagwi

East Sepik Province.

An ex-demonstration farm.

DATE OF BSTABLISHMENT

1975

SPECIES AND NUMBERS

Approximately 300 C. novaequineae

Approximately 100 C. porosus (97)

PRODUCTION AND TRADE

The operation produces a small number of skins, but mainly sells livestock to commercial farms. A few breeding-size animals are kept (97).

SOURCE OP ANIMALS

All animals are obtained from the wild (97):

YEAR

C. novaeguineae

C. porosus

1981

1515

384

1982

293

195

BUSBANDRY

The crocodiles are fed on locally purchased fish (97). OTHER INPORMATION

The maximum holding capacity of the farm in 1982 was about 3000 animals (59).

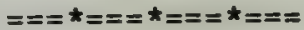

NAME OP OPERATION

Urimo Crocodile Farm

East Sepik Province.

The operation is intended as a rearing station for East sepik provincial Government stock. It is owned by the provincial Government (97).

DATE OF ESTABLISHMENT

1983

SPECIES AND NUMBERS

350 C. novaeguineae

150 C. porosus (97)

PRODUCTION AND TRADE

The operation will produce a few hundred skins a year and will possibly sell livestock to commercial farms (97).

SOURCE OF ANIMALS

In 1983 a total of 500 animals (detailed above) were obtained from the Angoram and Pagwi farms (97).

HUSBANDRY

The food is obtained from a local abbatoir (97). 


\section{PBILIPPINES}

At present there is one conservation-orientated operation breeding crocodiles in the Philippines, but no authenticated commercial farms. There is reported to be one private farm of unknown status. A Japanese consortium has expressed interest in establishing a commercial farm.

\section{NAME OP OPERATION}

Crocodile Breeding Project

Silliman University Marine Laboratory

near Dumaguete City

Negros Island.

Operated by the Silliman University Environmental Centre in conjunction with the Smithsonian Institution and the world Wildlife Fund.

DATE OF ESTABLISHMENT

$$
1980
$$

SPECIES AND NUMBERS

Crocodylus novaeguineae mindorensis: 25 including two breeding pairs and 11 hatchlings in September 1984 (4).

In 1982 the farm held an additional female $c . n$. mindorensis and one Crocodylus porosus (5).

\section{PRODUCTION AND TRADE}

The operation is an experimental project investigating conservation techniques and the viability of commercial farming. At present there is no commercial production.

SOURCE OP ANIMALS

All of the crocódiles have been obtained from captive sources, including both private collections and government projects on Mindanao and Luzon Islands (20).

BREEDING

The first pair of adults was acquired in 1980. In 1984 a second breeding pair was obtained (5); it was hoped that they would breed in 1985 (4).

One female $\mathrm{c}$. n. mindorensis laid three clutches totalling 32 eggs in 1981, however no surviving offspring were produced. In 198210 young were produced from 33 eggs, and 7 in 1983 from 20 eggs. This represents the first known captive propagation of this subspecies (5). Breeding took place again in 1984 when 12 young were hatched from 25 eggs laid (5). By September 1984 eleven of these were still alive (4).

BUSBANDRY

The animals are kept in two pens. One is used as a breeding pen $(15 \mathrm{~m} \times 11.6 \mathrm{~m})$, and has a large central oval pond $(11.1 \mathrm{~m} \times 3.8 \mathrm{~m} \times$ $1 \mathrm{~m}$ deep) with three small peripheral concrete ponds (5). The second pen is used for holding the animals; insufficient depth of water makes it unsuitable for breeding (20).

A second breeding pen measuring $14.5 \times 6 \mathrm{~m}$ with equal areas of land and water was built in 1984 (4).

The crocodiles are fed on locally caught and donated bats, cats, rats, dogs, frogs and insects. The carcases of experimental animals from the University are also used when available (20).

FINANCES

The Silliman University Environmental Centre, Smithsonian Institution, the World wildlife Fund and donations from government agencies finance the project $(20)$. 


\section{Philippines}

\section{RESEARCH AND PUBLICATIONS}

Areas of study include reproductive biology of the crocodile, growth in captivity, distribution and status of wild populations, feasibility of commercial crocodile farming and the use of crocodiles as an additional component of fish farming.

OTHER INPORMATION

The operators are looking for additional crocodiles for the breeding project. One of the objectives of the programme is to establish sanctuaries for release of captive-bred crocodiles. The farm is also being used as an educational base for crocodile conservation (20).

Two three-year-old crocodiles were planned to be released in Calauit wildlife sanctuary in late 1984 (4).

There are known to be a further $17 \mathrm{C}$. n. mindorensis in captivity in the islands of Luzon, Cebu and Negros (5).

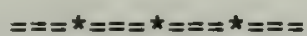

An association of 50 Japanese companies that manufacture products made from reptile skins has obtained financial support from the Japanese Government to start a crocodile breeding project (35):

NAME OF OPERATION

Japan Crocodile Farming Institute in the Philippines (Palawan)

DATE OF ESTABLISHMENT

Proposed for 1987 (35).

SPECIES AND NUMBERS

C. n. mindorensis: It is intended to start initially with a stock of 150 females and 50 males (26). (As the wild population is estimated to be less than 100 (5) it is difficult to see where these would come from.)

It is hoped eventually to breed 3000 crocodiles annually (35). PRODUCTION AND TRADE

The aim of the project is to conserve the near-extinct crocodile population in the area, eventually to re-introduce it to suitable areas to produce a sustainable yield of crocodile products.

The Institute intends to train project personnel and local residents in crocodile-farming techniques. The 6-year project is being jointly negotiated between the Japanese and Philippine Governments (26).

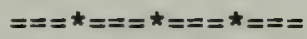

NAME OF OPERATION

Name unknown.

At San Ramon, Floridablanca, Pampanga.

Operated by: Mr Romeo Saldana.

DATE OF ESTABLISHMENT

1981.

SPECIES AND NUMBERS

Crocodylus porosus: parental breeding stock of 28 animals.

OTHER INFORMATION

Reported in 1983 to be in initial stages (6). 
In 1984 the office Rwandais du Tourisme et des Parcs Nationaux reported having given approval to a private enterprise to establish a wildlife farm utilizing crocodiles and several species of large mammals (90). A pilot project farming Crocodylus niloticus was reported to be in operation in 1984 (30). 


\section{SENBGAL}

It was reported in 1983 that there was a proposal to establish a crocodile (presumably crocodylus niloticus) farm in Casamance and that funds were being sought (77). 


\section{SINGAPORE}

A survey of crocodile farming operations, carried out by Internationaler Reptilleder-Verband E.V. established that there were three crocodile farms in singapore (74). However it is apparent that there are considerably more than this; many small-time farmers, who keep primarily pigs and chickens, feed the waste offal and carcases to some crocodiles (120).

Many crocodile skin businesses keep or have kept young wild crocodiles in back-yard enclosures, raising them until they are about two years old. Some of these establishments kept as many as 400 animals. The young animals were reported to be fed on a diet of shrimps and small fish until about $2 \mathrm{ft}(60 \mathrm{~cm})$ long. They were then fed on a diet of animal skins and intestines from abattoirs until they reached a length of $4 \mathrm{ft}(121 \mathrm{~cm})$ when they were killed (Singapore Trade, June 1961, fide 12).

According to king et al. (112), Crocodylus porosus has been extinct as a breeding resident in singapore for over 30 years. The large number of rearing farms flourishes in singapore by importing eggs and young from other Asian and Pacific areas. Stock is known to have been imported from Indonesia, Malaysia, Papua New Guinea, Australia, and the Philippines. Some limited breeding is done on the farms. Output from these farms is expected to decline as surrounding stocks decline.

Whitaker (200) visited two farms in 1984 and confirmed the presence of some Crocodylus novaeguineae. He asserted that "in general, claims of breeding can be discounted though an occasional nest may be produced".

Caiman crocodilus crocodilus and crocodylus novaequineae are both reported to be raised for both meat and skins in singapore (65).

\section{The Operations}

\section{NAME OF OPERATION}

Tan Moh Hong Reptile skin and Crocodile Farm

or Singapore Crocodile Farm.

782/790 Upper Serangoon Road, Singapore - 19.

DATE OF ESTABLISHMENT

The farm was established in 1945, and occupies a site of one acre ( 0.4 ha) of residential land (37).

SPECIES AND NUMBERS

A brochure produced by the farm shows photographs of crocodylus porosus and Tomistoma schlegelii ( 37 ).

A newspaper article mentions "sea crocodiles", "river crocodiles" and "alligators", reportedly from South-east Asia (10). Total stock approximately 600 (37).

Monitor lizards and pythons are also reported to be kept (37).

PRODUCTION AND TRADE

The farm is an integrated operation incorporating tanning and manufacturing facilities. Handbags, purses, wallets, belts, shoes and other souvenir items are produced. Crocodile meat is also sold, both as a delicacy and for medicinal use. The crocodiles are slaughtered at 3-5 years old. The products are sold in a farm shop and are also exported all round the world. Some whole skins are exported to F.R. Germany, France, Japan and other countries (37).

Some of the skins processed on the farm are imported (10). 
In promotional literature the farm states that "sea crocs offer the best skins. A handbag with the familiar sea croc markings of small scales can cost as much as $\$ \$ 850$, and $r$ iver crocodile is next down the 'scale', oddly because the scales are larger. Then comes the alligator." The farm sells belts from $\$ \$ 15$ to $\$ \$ 95$, and small alligator wallets from $\$ \$ 24$. (10)

The farm receives $300-400$ visitors a day (37). SOURCE OF ANIMALS

Some young reptiles are imported from Asian countries while most are "bred locally" (37).

\section{HUSBANDRY}

The crocodiles are kept in large concrete pools (10). The juveniles are fed on prawns and mussels while the older animals eat pigs' lungs and fish ( 37$)$.

The farm is linked to a country farm outside singapore where some 250 crocodiles are kept (10).

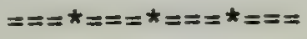

\section{NAME OP OPERATION}

Singapore Crocodilarium Pte Ltd

730 East Coast Parkway.

Parent company: Kaiyo Reptile Pte Ltd.

DATE OF ESTABLISHMENT

1979

SPECIES AND NUMBERS

Several hundred $C$. porosus are maintained as are a few dozen Tomistoma schlegelii $(102)$.

\section{BREEDING}

A 9-year breeding programe was initiated in 1982 (174).

\section{OTHER INPORMATION}

The operation takes the form of ranching and has been operating for several years (132). It is open to the tourists for exhibition of the live animals and for sale of crocodilian skin products (102). Depending on the success of the breeding programme, further similar farms may also be set up (174).

\section{$===*=ニ=*=ニ=*=ニ=$}

NAME OF OPERATION

544-C Lim Chu Kang Road,

Singapore (2470).

Owner: Mr Eng Gee Seng,

DATE OF ESTABLISHMENT

About 1975 (150)

SPECIES AND NUMBERS

The total stock was over 1800 in 1985. A photograph shows some Crocodylus porosus (150).

PRODUCTION AND TRADE

Skins are sold to local manufacturers of leather goods. The price was reported to be between $\$ \$ 100$ and $\$ \$ 600$ each $(150)$. 
SOURCE OF ANIMALS

The initial stock of 80 animals was obtained from Indonesia. In 1985 the farm was receiving about 50 young animals a month from Indonesia (150).

BREEDING

No breeding had taken place prior to 1985, but it was under consideration (150).

HUSBANDRY

The crocodiles are fed on chicken or pig offal, fish, prawns and cockles $(150)$.

OTHER INFORMATION

The farm also has about 600 pigs, some ducks and chickens (150). It is in an area where the Government has announced the intention of phasing out pig farms (120).

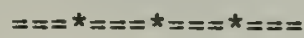

NAME OF OPERATION

Track 13

Punggol Road

Singapore (1954).

Owner: Mr Yang.

DATE OF ESTABLISHMENT

The farm was reported to be operating in 1980 (15).

SPECIES AND NUMBERS

The total stock was about 1000 in 1980. A photograph shows some Crocodylus porosus (15).

PRODUCTION AND TRADE

Skins were sold to local tanners about twice a year. Total annual production was about 400 in 1980 (15).

SOURCE OF ANIMALS

Animals were obtained from Indonesia (15).

HUSBANDRY

The crocodiles were kept in 16 enclosures (15). OTHER INFORMATION

The farm also had about 30000 poultry (15).

$==ニ *=ニ=*=ニ=*===$

A fifth farm is reported to exist in singapore which is operated by Leah Liang Joo. The farm started in 1970 with 60 crocodiles. By 1976 the stock had increased in size to 3000. Most of the crocodiles are probably $c$. porosus although some are reported to have been obtained from South America (208). 
The first crocodile farm in South Africa was established in 1968 outside Pretoria and has bred crocodiles regularly since 1970. From 1977 onwards several more farms were established around the country, and in 1983 formed themselves into the South African Crocodile Farmers' Association. In 1984 there were at least 12 farms with a total stock of about 2200 c. niloticus, mostly juveniles obtained from farms in Zimbabwe and South Africa. Breeding is planned at all farms but by 1983 had only occurred at three. The wild population of crocodiles in south Africa is very low, and to survive indefinitely all farms must therefore operate on a closed cycle. Many of the farms obtain income from tourists and the sale of livestock but none, except the original farm, anticipates being able to sell skins until at least 1988. It is not clear whether the latter has yet done so.

\section{Cape Province}

NAME OF OPERATION

Cango Crocodile Ranch Pty Ltd

Private Box 559

Oudtshoorn 6620 .

Di rector: P.H.S. Arnold.

DATE OP ESTABLISHMENT

The farm was established in 1977 and since that date has acted as a tourist interpretative centre but is not yet of commercial standing. SPECIES AND NUMBERS

Crocodylus niloticus: stock totals over 200 animals (39). PRODUCTION AND TRADE

In 1983 it was thought unlikely that this farm and others which belong to the South African Crocodile Farmers' Association would be able to produce skins before 1988 (38).

SOURCE OF ANIMALS

The farm was established in 1977 with a stock of 120 animals. One of these was an adult male supplied by the then Rhodesian Parks Board and the rest were reared from wild-taken eggs supplied by spencer's Creek Crocodile Farm, Victoria Falls, Zimbabwe. In 1978 a further five wild-caught aninals were obtained from the Rhodesian Parks Board. In 197960 ranched hatchlings were obtained from Sengwa Mouth Crocodile Ranch, Zimbabwe (39). All stock obtained since then has been purchased from the Natal Parks Board in the form of captive-bred juveniles of wild-caught parentage, totalling 50 animals in 1981 and 100 in 1982 (38).

BREEDING

In 19816 crocodiles were bred on the farm and in 198213 were bred. HUSBANDRY

Hatchling crocodiles are kept in tiled 'environmental tanks' which are temperature-controlled. older/adult animals are kept in open air enclosures, half land, half water, which have heated retreats for the crocodiles.

The diet consists of liver, offal, and ostrich by-products. FINANCES

The operation is self-financing. Some income is obtained from tourists (39). 
NAME OF OPERATION

Glenashby Crocodile Ranch

Glenashby

P. Bag X 513

East London

Cape Province.

Director: Ivan A. Kirk.

DATE OF ESTABLISHMENT

1983

SPECIES AND NUMBERS

C. niloticus: 48 juvenile animals are kept.

PRODUCTION AND TRADE

None as yet, production will eventually be of skins. SOURCE OF ANIMALS

The juvenile animals were obtained from zimbabwe but it is not yet clear whether they were from wild sources or from Zimbabwe crocodile ranches.

BREEDING

A breeding programme is planned. HUSBANDRY

The stock is held indoors in heated pools and is fed two or three times a week.

FINANCES

The farm is privately financed by the operator (113).

$$
==x_{*}==* *=\approx=* *==
$$

\section{NAME OF OPERATION}

Stewart's Farm

P.O. Box 4

Nkwalini

Cape Province.

Director: G.R.C. Stewart.

This farm was registered with the CITES secretariat as a recognised captive-breeding operation in August 1985 (101).

DATE OF ESTABLISHMENT

1979

SPECIES AND NUMBERS

C. niloticus: total stock, 80 animals in 1983 (171). 215 in 1984 (101).

PRODUCTION AND TRADE

The first skins from the farm were exported in 1985 (101). SOURCE OF ANIMALS

Three adult wild crocodiles have been caught in south Africa.

Captive animals have been obtained as follows (171):

Year

$\frac{\text { Year }}{1981}$

$\frac{\text { Adults }}{25}$

Juveniles

1982

1

13

\section{BREEDING}

It was reported in 1984 that some breeding had taken place. 27 out of 29 eggs kept in an incubator hatched successfully (93). 
South Africa

\section{HUSBANDRY}

Adult crocodiles are kept in open ponds. Juveniles are kept in hot houses. The diet comprises chicken, fish and beef (171).

A new hothouse is being built with viewing facilities for tourists (93).

BINANCES

The operation is said to be self-financing (171). 
Natal

NAME OF OPERATION

St Lucia Crocodile Centre

Private Bag

St Lucia Estuary

Natal 3936

Operated by the Natal Parks Board.

Director: D. Blake.

SPECIES AND NUMBERS

C. niloticus: main breeding enclosure contains 14 females, 5 males and young of unknown sex.

Osteolaemus tetraspis: 1 pair.

Crocodylus cataphractus: 2 males, 1 female (54).

In mid-1983 the Centre had 9 female, 2 male and 6 juvenile $c$. niloticus (148).

PRODUCTION AND TRADE

Over 400 live animals have been produced for sale to crocodile farmers, at R20 each (148).

OTHER INFORMATION

St Lucia crocodile Centre caters mainly for tourists, and is orientated towards public education on crocodiles. It has a small museum, a shop, aquaria and some live crocodiles.

Hatchling crocodiles are produced for restocking purposes and also for sale to crocodile farmers.

The Centre has a research role with a brief to monitor crocodile farming in Natal, and also to carry out investigations and produce recommendations on crocodile populations with special reference to Lake St Lucia. It has also functioned as an IUCN/SSC Crocodilian specialist Group breeding bank since 1975 (54).

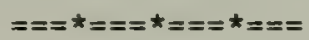

NAME OF OPERATION

River Bend Crocodile Farm

P.O. Box 245

Ramsgate 4285

Natal.

Director: N.H. Kelly.

DATE OR ESTABLISHMENT

October 1981

SPECIES AND NUMBERS

C. niloticus: total stock 117 animals in 1983 (111).

PRODUCTION AND TRADE

No products had been marketed by 1983 but it was planned that stock would be killed for their skins from 1987 onwards.

Live animals have been provided to two parks (111).

SOURCE OP ANIMALS

Animals have been obtained from crocodile ranches in zimbabwe and from crocodile farms in South Africa (148). Stock has been obtained as follows (111):

\begin{tabular}{ccc} 
Year & Adults & Juveniles \\
\cline { 1 - 2 } & 0 & \\
1982 & 2 & 0 \\
1983 & 1 & 44
\end{tabular}




\section{BREEDING}

A breeding programme is planned and it was hoped that stock would first produce eggs in the $1983 / 1984$ breeding season (111). HUSBANDRY

The farm has large open breeding pools with five different levels varying from $2 \mathrm{~m}$ to $2 \mathrm{~cm}$ deep and stocked with two species of fish. Sand nesting areas are provided as well as shade, lawned area and cement basking area. Indoor accommodation has under-floor and ceiling heating and solar-heated water is provided for crocodiles under $1.5 \mathrm{~m}$. The stock is fed on fish and chicken; the animals kept outside are fed one whole chicken rolled in bone meal each week (111).

FINANCES

The farm is self-financing, depending on tourists for income. OTHER INPORMATION

Educational slide shows are offered to the public on open days. The farm is a member of the South African Crocodile Farmers' Association. (111).

$$
==* \star=ニ *=ニ * *==
$$

NAME OF OPERATION

Crocworld

Crookes Brothers Ltd

P.O. Renishaw

South Coast Natal, 4181.

Manager: A.C. Pooley.

DATE OF ESTABLISHMENT

January 1984.

SPECIES AND NUMBERS

C. niloticus: a permit is held for keeping a total stock of 8500 crocodiles (149).

PRODUCTION AND TRADE

It is envisaged that the first hides will be available for sale in 1987/88. Income will also be derived from a tourist complex (149).

SOURCE OF ANIMALS

A permit has been granted to obtain 72 adult crocodiles $(60$ females and 12 males) from Malawi during 1984. It was hoped to purchase 1500 hatchlings from commercial farms in zimbabwe. Thereafter the farm will be self-supporting (149).

BREEDING

A breeding programme is planned.

\section{HUSBANDRY}

The farm has four controlled-environment buildings to house up to 2000 hatchlings for the first year of life. The buildings are designed to take advantage of winter sunshine, and are air-conditioned for the hot summer weather. From one year until slaughter at about 3.5 years the crocodiles will be kept in open stock ponds where they will be regularly graded. Breeding ponds are laid out in areas of natural bush with viewing paths and walkways for visitors. There is an incubation room with capacity for 5000 eggs under controlled temperature and humidity. A cool store has been built to contain up to 40 tons of food (149). 


\section{OTHER INFORMATION}

Tourism will be an important aspect of the farm. A scenic drive has been built from the main coast road and there will be a large restaurant with a playground and curio shops; this complex should be open by the end of 1984. Educational facilities are planned with a lecture room and nature trails. There will also be wildife exhibits, possibly including some exotics.

In the longer term, fish farming is being considered, using the effluent from the rearing ponds for catfish (Clarias spp.) and Tilapia spp. The fish will eventually be fed to the crocodiles (149).

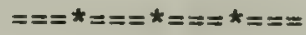




\section{Transvaal}

NAME OP OPERATION

Croco Farm

De Wildt

near Pretoria, Transvaal.

Postal address: P.O. Box 18100, Hercules, 0030 Pretoria.

Director: Jan-Gerd Kuhlmann.

DATE OF ESTABLISHMENT

Project started privately in 1968 (114); became commercial in 1978. SPECIES AND NUMBERS

C. niloticus: Total stock about $600-700$ animals (182). PRODUCTION AND TRADE

The purpose of the farm is to provide crocodiles for restocking into game reserves, as well as for commercial use (114). Although some reports indicate that crocodiles are released into South African rivers (11), there appears to have been no release to the wild so far. A 1978 report indicated the aim of the farm to produce 2000 crocodiles a year (9).

Crocodile products entering trade from the farm are marked to show that they are not from wild animals (114).

SOURCE OF ANIMALS

The farm was established with 14 mature 'nuisance' crocodiles caught in the Republic of South Africa under permit from the South African Nature Conservation Division. This is the only stock gained from the wild by the farm (114).

It is reported that 20 unsexed two-year-old crocodiles were purchased from Binga Crocodile Farm, Zimbabwe in August 1976 (182). BREEDING

All breeding has been from the original 14 crocodiles, which have been breeding in captivity since 1970. The farm is now beginning to breed third generation captive stock and is said to be a closed-cycle operation (114).

HUSBANDRY

The farm covers 20 ha (145). Breeding crocodiles are kept in landscaped concrete pools; eggs are hatched in incubators; hatchlings are kept in nurseries under controlled conditions; and young crocodiles are kept in hot-houses until they are ready for marketing (114). FINANCES

The farm is privately financed by Jan-Gerd Kuhlmann (114).

$$
==\approx *==\approx \star=\approx=*= \pm=
$$

NAME OF OPERATION

Sabie Crocodile Farm

P.O. Box 1410

Pretoria 0001.

Director: Trevor C. Bond.

DATE OF ESTABLISHMENT

May 1981

This farm and its stock were reported to be for sale in 1984 (54). SPECIES AND NUMBERS

C. niloticus: in April 1983 stock totalled 444 animals, 12 adults, 394 juveniles and 38 animals under one year old. 


\section{PRODUCTION AND TRADE}

The operation was not producing commercially in 1983. Production will be based on skins. Skins produced on the farm will be marked to indicate that they are from farmed animals.

SOURCE OF ANIMALS

Two animals were obtained under permit from the Kruger National Park, onto which the farm borders, in March 1981.

Stock has been obtained from the Natal Parks Board, the Cango Crocodile Ranch and Kariba Crocodile Farm in zimbabwe as follows:

$\begin{array}{ccc}\frac{\text { Year }}{1981} & \frac{\text { Adults }}{8} & \frac{\text { Juveniles }}{144} \\ 1982 & 4 & 250\end{array}$

\section{BREEDING}

In the $1982 / 1983$ breeding season 38 animals were bred on the farm. HUSBANDRY

The farm has earth-floored breeding pens skirted by concrete and containing natural and concrete rearing pens which are scrubbed out every 24 hours. Each pen type is surrounded by chain-link fence, has flowing water and natural shade. Further shade is provided by large cloths where necessary. The crocodiles are fed on meat provided by the culling operation in the Kruger National Park.

BINANCES

The farm is a commercial enterprise, run by five partners. OTHER INFORMATION

The taking of wild crocodiles in south Africa is controlled by the Transvaal, Natal, Cape Province and orange Free state Governmental Administrations.

The breeding which occurred in $1982 / 1983$ was the first captive breeding to have taken place in the Transvaal.

Infertile or arrested eggs are blown and sold as curios. There are tourist facilities and a shop. The farm is situated on the main road near the Skukuza Gate of the Kruger Park, and is therefore well-placed for attracting tourists $(60)$.

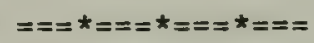

\section{NAME OF OPERATION}

Crocodile farm

Post Locker 21

1565 Volkskas Centre

Pretoria 0002 .

Director: H.O. Penzhorn.

This farm was registered with the CITEs secretariat as a recognised captive-breeding operation in July 1985 (101).

DATE OF ESTABLISHMENT

February 1982

SPECIES AND NUMBERS

C. niloticus: total stock 200 in 1983 (140).

PRODUCTION AND TRADE

It is thought that skins from the farm were exported in 1985 (101). 
SOURCE OF ANIMALS

No stock has been taken from the wild. The following stock has been obtained (140):

$\frac{\text { Year }}{1982} \frac{\text { Adults }}{0} \quad \frac{\text { Juveniles }}{100}$

$1983 \quad 0 \quad 100$

BREEDING

None by $1983(140)$.

PINANCES $(140)$.

The farm is privately financed but was not self-financing in 1983

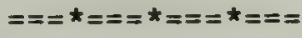

NAME OF OPERATION

Crocodile farm

Tzaneen (Farm Langbult)

Aqatha

Transvaal.

Director: Milan Darazs.

DATE OF ESTABLISHMENT

November 1982

SPECIES AND NUMBERS

C. niloticus: a total of 36 animals were held in 1983: 3 adults and 33 juveniles (69).

PRODUCTION AND TRADE

None by $1983(69)$.

SOURCE OF ANIMALS

The stock has been obtained from Zimbabwe and from an aquarium in pretoria, South Africa (69). It is not yet clear whether the animals from Zimbabwe are of ranch or wild origin. BREEDING

There are plans for a breeding programme. HUSBANDRY

The stock is held in three enclosures, each $20 \mathrm{~m} \mathrm{x} 30 \mathrm{~m}$ and is fed on fish and chicken (69).

FINANCES

The farm is privately financed (69).

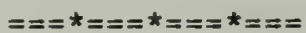

NAME OF OPERATION

Crocgrove Farm

Box 112

Schagen 1204

Transvaal.

Director: Michael Slogrove.

DATE OF ESTABLISHMENT

1983

SPECIES AND NUMBERS

C. niloticus: about 50 adults and sub-adults. PRODUCTION AND TRADE

The operation was not producing commercially in 1983. Production will be based on skins (168). 
SOURCE OF ANIMALS

About 50 animals, mainly females with enough males for breeding, were captured in the Caprivi strip (Namibia) and imported under permit (168).

BREEDING

HUSBANDRY

It is intended that breeding will take place.

The farm has large open-air ponds, surrounded by concrete and chain-link fence in which the broodstock are kept. It is intended that eggs will be laid in the soil amongst natural vegetation surrounding the ponds. Concrete rearing pens have been constructed to house any hatchlings and there is also a new block of buildings including an incubator room and food store (168).

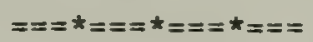

\section{NAME OP OPERATION \\ Lomati Estates \\ Malelane \\ Transvaal. \\ Director: P.J. Schoeman. \\ SPECIES AND NUMBERS}

C. niloticus: 14 breeding females

6 breeding males

200- hatchlings

$20+$ production stock ( 82 ).

\section{PRODUCTION AND TRADE}

The operation was not producing commercially in 1985. Production will be based on skins (82).

SOURCE OF ANIMALS

The broodstock was imported from Zimbabwe (82).

\section{BREEDING}

In 1984 approximately 200 hatchlings were produced from eggs laid on the farm. About 500 eggs were laid in 1985 which were expected to yield some 400 hatchlings ( 82 ).

\section{HUSBANDRY}

The broodstock is kept in an open pen of about $100 \mathrm{~m}$ by $30 \mathrm{~m}$ containing an artificial lake with a maximum depth of $2 \mathrm{~m}$. Breeding cubicles are located around the perimeter wall, and are floored with clean sand. The eggs are removed within $24 \mathrm{~h}$ of laying and are incubated in polystyrene boxes filled with vermiculite. After hatching, the young are transferred to circular corrugated iron tanks, about $2 \mathrm{~m}$ in diameter, and kept at $30^{\circ} \mathrm{C}$ for about the first year of life. Later they are moved to a hothouse with a transparent roof, where they are kept in concrete pens with sloping floors. Each pen holds about 20 females which are being raised as broodstock. Water temperature is not controlled and all heating is by natural sunlight.

Chicken carcases are provided as food, supplemented with vitamins and minerals (82).

\section{FINANCES}

It is planned to slaughter the animals at about three years old when they have reached a minimum of $30 \mathrm{~cm}$ belly width. Current skin prices were estimated to be R100 to R150 in 1985 (82). 


\section{$\underline{\text { SPAIN }}$}

A company known as Iberia Enterprises Ltd. requested "as many crocodiles as could be supplied" from the Natal Parks Board, Republic of South Africa, for unspecified purposes in 1979. The request was turned down. The species involved would have been crocodylus niloticus. The address of the company is:

Iberia Enterprises Ltd

Felipe Bertron y Güell

3 tda 4

Barcelona.

Directors: W. Martin Schutte; Roy Bates; Carmen Cano Canalis (146). 


\section{SRI LANKA}

The CITES Management Authority reported in 1983 that there were no farms or ranches in Sri Lanka, although there had been several attempts to start such operations (71). The estimated total number of captive Crocodylus palustris in Sri Lanka in 1982 was 20 (197). 


\section{SURINAME}

A caiman farm was reported to exist in suriname in 1979 (155): however no further confirmation of this farm has been found and its continued existence must be considered as dubious:

\section{NAME OF OPERATION}

Crocodile Parm of Suriname, N.V.

Groningen, District Saramacca.

SPECIES AND NUMBERS

Caiman crocodilus: numbers unknown.

PRODUCTION AND TRADE

skins were reported to be being exported, most likely to France, but possibly to the Netherlands and Germany (155).

SOURCE OF ANIMALS

The animals on the farm were probably caught on the Coesewijne River (155). 
The Taiwan Provincial Department of Agriculture and Forestry supplied the following details of crocodilian farms in Taiwan $(177,178)$ :

There are 35 farms in Taiwan, the first of which was established in 1976 (177). SPECIES AND NUMBERS

"South American short-mouthed caiman" (Caiman crocodilus): about 8000

"Indian sharp-mouthed crocodile" (Gavialis gangeticus): about 300

"SE Asia estuary crocodile and others" (Crocodylus porosus): about 300 $(177)$.

Fuchs (79) reported that there were some Tomistoma schlegelii on one farm, but Tsai (178) also confirmed the existence of some $G$. gangeticus. There are unconfirmed reports that some Alligator mississippiensis were obtained from the USA during 1984 by Taiwanese farmers.

PRODUCTION AND TRADE

Annual production from all farms (US\$1 = NT\$39):

Product Weight $(\mathrm{kg}) \quad$ Value (NT\$)

$\begin{array}{lrr}\text { Skins } & 12500 & 10 \text { million } \\ \text { Meat } & 30000 & 12 \text { million } \\ \text { Other } & 7500 & 8 \text { million }\end{array}$

Most of this is seld within Taiwan but some is exported to Japan and Korea (177).

The meat is sold for food rather than medicinal use, except those parts of the skeleton, blood, and male genitalia which have medicinal value. The skin is processed for leather manufacture (178).

BREEDING

About 2000 hatchlings are produced each year on the farms. Each mature female lays about 25-45 eggs with a hatching rate of 458 (177).

HUSBANDRY

Ponds are usually of concrete with a soil bottom and are surrounded by brick walls.

Juvenile crocodilians under 10 inches $(25 \mathrm{~cm})$ are fed on small fish and insects while larger animals are fed chickens and pig offal (177).

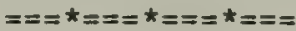

Fuchs (79) supplied the following details of a farm that he had visited:

NAME OF OPERATION

Taiwan Crocodile Ltd

Nr. 225 Shin Chung Road

Matou/Tainan 
SPECIES AND NUMBERS

Caiman crocodilus crocodilus: a total of 5200 are kept:

48003 months old, $0.3 \mathrm{~m}$ long.

801.5 years old, $1.2 \mathrm{~m}$ long.

3207 years old, $2.4 \mathrm{~m}$ long.

Crocodylus porosus: a total of 30 one-year-old animals.

Tomistoma schlegelii: A total of 15 one-year-old animals. PRODUCTION AND TRADE

skins and meat. The meat is worth Us\$26.7 $\mathrm{kg}^{-1}$ including bones. BREEDING

2700 eggs are laid each year on the farm with a hatching success rate of $13 \%$ to $15 \%$. It appears that 300 of the breeding stock were bred on the farm.

HUSBANDRY

The farm covers an area of $7500 \mathrm{~m}^{2}$ with two $60 \mathrm{~m} \times 60 \mathrm{~m}$ 'natural' lakes; four $10 \mathrm{~m} \times 10 \mathrm{~m}$ concrete ponds; two gas-heated greenhouses, each $20 \mathrm{~m} \times 10 \mathrm{~m}$ and containing twelve $2.5 \mathrm{~m} \mathrm{x} 2.5 \mathrm{~m}$ concrete ponds. Crocodiles are killed at two years old when they are about $1.5 \mathrm{~m}$ long and weigh about $15 \mathrm{~kg}$. The crocodiles are fed on chicken and freshwater fish (79).

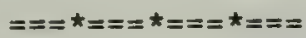

The following company wanted to purchase 1000 live hatchling C. niloticus, from the Natal Parks Board, Republic of South Africa, for import to Taiwan in 1979; the purpose was unspecified.

The EHISN International Corporation,

6th Fl. Chinar Rebar Building,

372 Lin Sen Nurih Building, 372 Lin Sen Nurih Rd,

Taipei (146). 
One crocodile farm was established in 1981 but closed down within four years for financial reasons. There are plans to establish another farm in another locality where there is readily available cheap food (176). Details of the original farm are given:

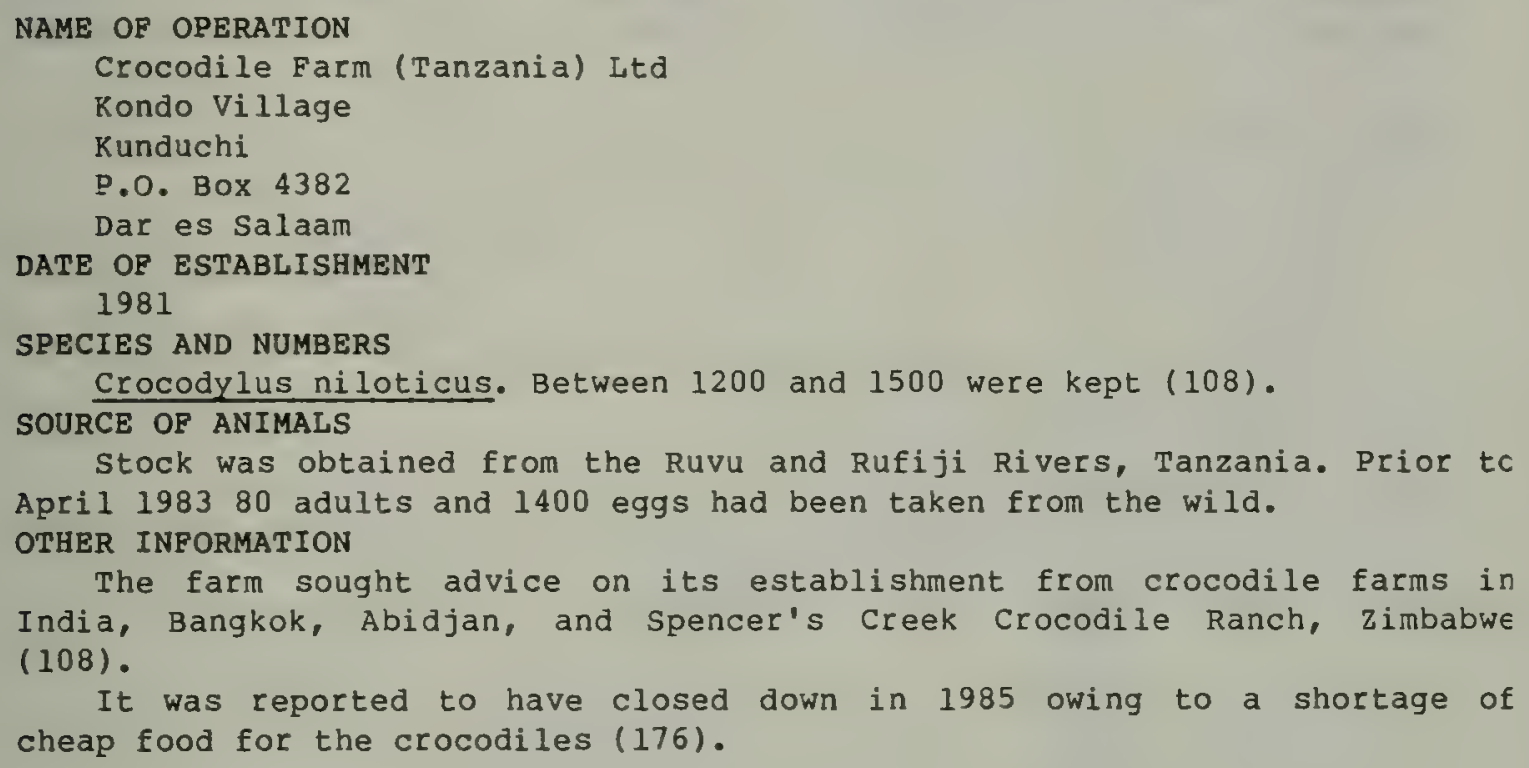


There is only known to be one crocodilian farm in Thailand. In 1985 this farm achieved regognition by the cITEs secretariat as an approved captive-breeding operation for Crocodylus siamensis, Crocodylus porosus and hybrids between the two. It is not yet (June 1985) an approved breeding operation for the other Appendix I species kept (Tomistoma schlegelii, Crocodylus rhombifer, Alligator sinensis).

NAME OF OPERATION

The Samutprakan Crocodile Farm and Zoo Co. Ltd

777 Mou 4 Taiban Road

Samutprakan

Thail land.

Founder: Utai Youngprapakorn. General Manager: Charoon Youngprapakorn.

DATE OF ESTABLISHMENT

1950. Became commercial in 1960.

SPECIES AND NUMBERS

over the years the total farm stock has been reported as follows:

\begin{tabular}{lll}
$\frac{\text { Year }}{1972}$ & \multicolumn{3}{l}{ Numbers } \\
\cline { 2 - 3 } 1973 & $12378(212)$ \\
1974 & $13637(212)$ \\
1975 & $12517(212)$ \\
1976 & $16980(212)$ \\
1980 & $20300(212)$ \\
1983 & $24500(173)$ \\
1984 & $30000(211)$ \\
& $10568(172)$
\end{tabular}

The age and species composition of the stock in 1984 was reported to be $(172)$ :

\begin{tabular}{llll} 
Breeding & stock & \multicolumn{3}{c}{ Immatures } \\
Male & Female & $1-5$ yrs & $6-9$ yrs
\end{tabular}

\begin{tabular}{lrrrrr} 
C. siamensis & 1157 & 1713 & 3860 & 850 & 7780 * \\
\hline C. porosus & 290 & 540 & 510 & 415 & 1755 \\
Hybrids & 112 & 208 & 270 & 120 & 710 \\
T. schlegelii & 2 & 3 & 0 & 80 & 85 \\
C. crocodilus & 8 & 15 & 202 & 0 & 225 \\
C. novaeguineae & 2 & 3 & 0 & 0 & 5 \\
A. sinensis & 1 & 1 & 0 & 0 & 2 \\
A. mississippiensis & 1 & 1 & 0 & 0 & 2 \\
C. rhombifer & 0 & 0 & 4 & 0 & 4 \\
TOTAL & & & & 10568
\end{tabular}

* Including 200 additional animals over 9 yrs old.

This represents a considerable reduction from the stocks of 11700 Crocodylus siamensis, 8550 Crocodylus porosus and 4100 hybrid C. siamensis $\times C$. porosus reported earlier (173). Whitaker (203) reported 
170 T. Schlegelii, of all sizes, in 1981. In 1982 the farm also had one Caiman latirostris and one paleosuchus palpebrosus (173). PRODUCTION AND TRADE

The crocodiles are bred for meat, skins and teeth, and are a tourist attraction. An average three-year-old c. porosus weighs $10-18 \mathrm{~kg}$. Of the average $14 \mathrm{~kg}$, approximately $5-7 \mathrm{~kg}$ of meat is marketable (173).

crocodiles reared for skins are usually slaughtered at three years. Between 1980 and 1982 skins were produced as follows (209):

$\begin{array}{ll}\text { Year } & \frac{\text { No. of skins }}{\text { produced }} \\ 1980 & 900 \\ 1981 & 200 \text { (few were slaughtered due to } \\ 1982 & \text { low market price for skins) }\end{array}$

The marked reduction in the total stock of crocodilians from 30000 in 1983 to 10568 in 1984 suggests either that the earlier figure was incorrect or that substantial slaughtering or other mortality occurred during 1983 and 1984.

PRODUCTION AND TRADE

Sixty percent of the skins are processed and sold locally, mostly to tourists, while the other $40 \%$ are salted and shipped abroad (173). In 1974 the farm was-supplying $80 \%$ of the Thai crocodile skin trade. The skins traded are not marked to show their origin (209). Early trade used to be directed towards Europe alone, mostly France (211).

of the skins produced on the farm in 1980, 700 were sold to France and 800 to Japan, in 1981400 to France and 500 to Japan, and in 1982 all the skins were sold to Japan (209).

The meat is sold locally, mostly to restaurants as a delicacy (for US\$5 $\mathrm{kg}^{-1}$ ); it is also used as a treatment for asthma (173). The meat is sold fresh on the local market with the surplus being dried and sold to Chinese tourists at the farm's shop.

The average value of a crocodile (skin plus meat) was about US $\$ 320$ in 1983. The skin business has slowed down since mid-1982. It is reported that the unprocessed skin of a three-year-old $C$. porosus sold for about US $\$ 250$ and the skin of $\mathrm{C}$. siamensis sold for about 108 less (173). A more recent report (1984) put the value of skins at US\$90 each (57).

Other trade is in teeth, which can be used as an ingredient of Thai medicine (210), and in live animals to zoos (209). Whitaker et al. quote values of US\$10 a $\mathrm{kg}$ for dried meat, US\$15 for lacquered heads and US\$3 for feet in Thailand (204).

In 1980 only one crocodile, an albino $\mathrm{C}$. porosus female, was sold to a zoo, the Glady Porter $z \circ 0$, Brownsville, Texas. No crocodiles were sold to zoos during 1981 or $1982(210)$.

SOURCE OF ANIMALS

The operation began with 20 wild-caught $C$. siamensis in 1950. According to Youngprapakorn (209) no animals (presumably of C. siamensis and $c$. porosus) have been taken from the wild since 1952. The C. crocodilus, C. novaeguineae, A. sinensis, C. latirostris and P. palpebrosus were acquired through the efforts of IUCN/SSC Crocodile Specialist Group, New York Zoological Society and the first working 
meeting of the IUCN/SSC Crocodile Specialist Group in 1971 (173).

Six Cuban crocodiles have been obtained through a dealer from a $z 00$ in Czechoslovakia (211).

BREEDING

In 1960150 young were hatched; in 1970 the hatch was 3500 (12). Between 1950 and 1972 the farm's crocodile population increased at 10-158 annually (40).

In 1975 the farm held a breeding herd of 1000 animals; by 1975 this had increased to 3000. In 1976 the farm reported that 5740 eggs had been laid in captivity, with a 608 hatching success $(40)$.

C. porosus, $C$. siamensis and $C$. crocodilus are regularly bred beyond second generation; T. schlegelii has bred to Fl (209).

In $C$. porosus hatch rate is 40-508; in C. siamensis hatch rate is 50-608. From 10-158 of hatchlings (or up to 30\% according to Leather magazine (12)) die in their first year, then mortality drops to below $58(173)$. Recent breeding $(209,210)$ :

Number hatched Number survived

\section{C. porosus}

1980

1981

1982

1984

c. siamensis

1980

1981

1982

1984

Caiman crocodilus

1980

1981

1982

1984

Tomistoma schlegelii

1980

1981

1982

\section{in captivity}

1200
1320
1410
399

3550
3670
3750
2050

16

4

7

32

15

20

22

30 days ( $* 1 \mathrm{yr})$

1165 (209)

1280 (209)

1375 (209)

$365(172)$

3515 (209)

3625 (209)

$3730(209)$

* 1855 (172)

$14(210)$

$3(210)$

$6(210)$

* $32(172)$

$12(210)$

$18(210)$

$20(210)$

The breeding success in 1984 was reported (172) to be:

\begin{tabular}{|c|c|c|c|c|c|c|c|}
\hline & \multirow{2}{*}{$\begin{array}{l}\text { No. of } \\
\text { clutches }\end{array}$} & \multicolumn{3}{|c|}{ Eggs/clutch } & \multicolumn{3}{|c|}{ Hatchlings/clutch } \\
\hline & & $\operatorname{Max}$ & $\operatorname{Min}$ & Mean & $\operatorname{Max}$ & Min & Mean \\
\hline C. siamensis & 100 & 45 & 20 & 32.5 & 41 & 0 & 20.5 \\
\hline C. porosus & 17 & 55 & 26 & 40.5 & 47 & 0 & 21.5 \\
\hline Hybrids & 17 & 58 & 30 & 44.0 & 53 & 23 & 37.5 \\
\hline C. crocodilus & 2 & 20 & 14 & 17.0 & 20 & 12 & 16.0 \\
\hline
\end{tabular}




\section{HUSBANDRY}

The total area of the farm in 1984 was 24.25 acres ( 9.81 ha) but there was a further 8.08 acres $(3.27 \mathrm{ha})$ available for expansion in the future (172). Pond facilities were listed as follows:

Breeding ponds (172):

$\begin{array}{lll}\text { Dimensions (m) Water } & \begin{array}{l}\text { Land } \\ \text { area (ha) area (ha) }\end{array}\end{array}$

$\begin{array}{lrrlll}44.5 & \times & 146 & 0.34 & 0.34 & \text { C. siamensis } \\ 37 & \times & 44 & 0.09 & 0.06 & \text { Hybrid } \\ 65 & \times & 81 & 0.27 & 0.27 & \frac{\text { C. siamensis }}{T . \text { schlegelii }} \\ 27.5 & \times & 43 & 0.03 & 0.08 & \frac{\text { C. siamensis }}{\text { C. crocodilus }} \\ 84.5 \times & 9 & 0.07 & 0.03 & \frac{\text { C. porosus }}{\text { C. porosus }} \\ 12 & \times & 12 & 0.01 & 0.01 & \text {. }\end{array}$

Rearing ponds for immature animals (172):

Dimensions $(\mathrm{cm}) \quad$ No. of ponds

$\begin{array}{rrr}200 \times 200 & 60 \\ 1600 \times 800 & 35 \\ 800 \times 600 & 6 \\ 400 \times 400 & 50 \\ 25 & \times 50 & 240 \\ 50 & \times 65 & 51 \\ 300 \times 300 & 4 \\ 1000 \times 500 & 1\end{array}$

Each pond is surrounded by a land area larger than the water irea, with areas of sand and grass and trees to provide shade. The breeding ponds are $1.5 \mathrm{~m}$ deep, irregular in shape, with circulating fresh water. Fish are dumped in adjacent feeding ponds at 18.00 hours every day. These pools are cleaned out daily after feeding and any excess food is removed (173).

In each breeding pool the sex ratio is one male to three females. crocodiles are fed on waste fish, but if the supply is inadequate it is supplemented with chicken wings, legs and necks. The young do not feed for the first 7-10 days but are then fed coarsely-chopped fish until large enough to be fed on whole fish (173).

Around the breeding ponds are 150 roofless nesting stalls, each with a drainage ditch and each approximately $4 \times 4 \mathrm{~m}$ with a $60 \times 60 \mathrm{~cm}$ door facing the pool. Nesting material (dried grass and other vegetation) is provided for both $c$. siamensis and $c$. porosus, by placing it in the stalls. Once the eggs are laid, the females are chased out of the pens and all further care is carried out by the farm 


\section{Thailand}

staff. The nest temperature is checked at regular intervals each day and steps are taken to keep the temperature at $95-98^{\circ} \mathrm{F}\left(35-37^{\circ} \mathrm{C}\right)$. The humidity is also monitored and kept as constant as possible. Upon hatching, the young are placed in a concrete nursery pool $30 \mathrm{~m} \times 2 \mathrm{~m}$ for 7-10 days. As the young animals grow they are moved to successively larger tanks but are always kept in crowded conditions with others of the same age (173).

\section{PINANCES}

The farm was opened to the public in 1969 and by 1971 was receiving 3000 visitors a week at a cost of $30 k$ each adult, 15k each child, and $\$ 1$ for foreign tourists. The farm now receives about one million visitors annually. Income also accrues from a gift shop, refreshment stands, elephant rides, photographers with tame pythons, stands selling fish to feed the crocodiles and assorted amusements. Some of the first-year hatchlings that die naturally are stuffed and sold as souvenirs (173).

The major continuing cost is food; approximately 4000-5000 kg of waste fish are needed daily at a cost of US\$0.20 $\mathrm{kg}^{-1}(173)$.

OTHER INPORMATION

The farm was established with the following objectives (212):-

a) Preservation of crocodiles;

b) Comnercial production:

c) Tourism.

It is the only major farm in that part of the world producing commercial quantities of crocodiles (40). Tiger, snake and lizard farms are also planned by the farm (173).

Besides the crocodilians there are 48 other species of native and exotic reptiles on show (173), as well as birds and mamals. Pythons are kept in large numbers and are bred (211). Other species kept include elephant, lion, tiger, leopard, chimpanzee, gibbon, deer, bears, wild pigs, civets, wild cats and birds $(57,172)$. The animals are reported to be kept in small, dirty pens (57).

'Leather' magazine (12) named Samutprakan Crocodile Farm, near Bangkok, as the 'Gordon Choisy Crocodile Farm'. Gordon Choisy own a leather tannery in Paris, France. 


\section{TOGO}

A crocodile (presumably crocodylus niloticus) farming project was expected in 1983 to be set up "in the near future" (75). 


\section{UGANDA}

The Kajansi Pish Culture Station, $12 \mathrm{~km}$ south of Kampala, introduced a crocodile-rearing programe, in 1959, as a conservation measure. In 1984, 18 very large Crocodylus niloticus and a number of smaller animals were being kept in neglected pens. The station is in danger of discontinuing its crocodile rearing as it cannot afford food for the crocodiles (43). 


\section{General Information}

The first records of "farming" alligators in the USA date from the end of the last century when a few entrepreneurs started keeping alligators as tourist attractions (40). Such operators continue today and, in Louisiana, are now termed "exhibitors" to distinguish them from "farmers" who are interested in the commercial products of alligators: skins, meat and live sales. The first commercial farms started in Louisiana, in 1954, but very few skins were produced (105). Farms were later established in Florida but they developed at a slow rate, and it was not until the summer of 1978 that they sold their first captive-raised skins (40).

SPECIES AND NUMBERS

The only species of crocodilian which is farmed commercially in the USA is Alligator mississippiensis. The table gives a summary of the numbers of farms which have been in existence in Louisiana (LA) and Florida (FL). Although the total numbers of farms in Louisiana has not changed much, many individual farms have been put into liquidation and new farms have started up. One farm is reported in Texas.

\begin{tabular}{|c|c|c|c|c|c|c|c|}
\hline & & $\begin{array}{l}\text { No. of } \\
\text { farms }\end{array}$ & $\begin{array}{l}\text { Alligator } \\
\text { stóck }\end{array}$ & $\begin{array}{l}\text { Skins } \\
\text { harvested }\end{array}$ & $\begin{array}{l}\text { Nests on } \\
\text { farms }\end{array}$ & $\begin{array}{l}\text { Hatchlings } \\
\text { produced }\end{array}$ & \\
\hline 1954 & LA & 6 & - & - & - & - & (105) \\
\hline 1975 & LA & 8 & 8357 & - & 26 & 493 & (105) \\
\hline 1976 & LA & 7 & 8261 & - & 42 & 713 & (105) \\
\hline 1977 & LA & 9 & 9162 & - & 59 & 889 & (105) \\
\hline \multirow[t]{2}{*}{1980} & LA & 8 & 13000 & - & - & 1500 & $(40)$ \\
\hline & FL & 5 & 7000 & - & - & 2500 & $(40)$ \\
\hline 1983 & FL & 12 & - & - & - & - & (83) \\
\hline \multirow[t]{2}{*}{1984} & LA & 9 & 16829 & 1113 & 73 & 1800 & (103) \\
\hline & FL & 19 & 32193 & 738 & $335+$ & 4075 & $(67)$ \\
\hline
\end{tabular}

Many zoos and exhibitors keep a variety of other crocodilian species, one of the most important conservation operations being for Crocodylus moreletii, which has been bred in large numbers by the Atlanta Zoological Society. About 150 of these have subsequently been released in Mexico. Other species which have been bred include Crocodylus intermedius, Crocodylus sianensis, crocodylus acutus, Crocodylus niloticus, crocodylus porosus, crocodylus rhombifer, Crocodylus cataphractus, Alligator sinensis, Caiman crocodilus, Osteolaemus tetraspis and paleosuchus trigonatus (186). 
U.S.A.

\section{PRODUCTION AND TRADE}

Harvesting of wild alligators takes place in Florida, Louisiana and on a small scale in Texas. In 1983 the harvest in Louisiana amounted to 16154 alligators, 88 of the estimated population, and produced $100000 \mathrm{lb}(45.5 \mathrm{t})$ of meat (195). The total skin production from farms in the state in 1984 was 1113 (103). Total farm skin production in Florida was 112 in 1983 but a further 1031 live animals were sold (25). In 1984 a total of 738 skins were produced from farms in Florida (67).

In 1981 there were more than 200 restaurants serving alligator meat in Florida. Farm-raised meat was said to fetch a premium price because of better processing and to have sold for us\$10 a pound $\left(\$ 22 \mathrm{~kg}^{-1}\right)$. Other by-products such as feet and heads as curios and gall bladders and penes for the Far Eastern market were said to be potentially valued at up US\$20-50 per animal although with current marketing practice US $\$ 5$ would be a more reasonable sum (41). Whitaker et al. (204) quoted more modest prices in 1985 of US $\$ 10 \mathrm{~kg}^{-1}$ for meat and US $\$ 20$ for lacquered skulls in the USA, with US $\$ 25 \mathrm{~kg}^{-1}$ for oil, US\$5 each for dried gall bladders and US\$5 a pair of dried scent glands obtainable in Hong Kong.

In Florida licences are issued to take "nuisance" alligators, and up to 1980 about 2000 such animals were being taken each year (30). An experimental harvest was initiated in 1981 on the Orange and Lochloosa Lakes and, until 1984, an annual average harvest of 330 alligators greater than $1.2 \mathrm{~m}$ in length was taken (96).

All trade in alligator products, whether farmed or wild-caught, is strictly regulated. Skins and meat must be tagged or labelled with tags issued by the state Authorities, and the killing and sale or processing of products of alligators also require licences. Alligator mississippiensis is listed on the US Endangered Species Act, and tanners of alligator skins and buyers who wish to engage in inter-state commerce of raw skins must hold a permit from the US Fish and Wildife Service (USFWS). The killing of alligators reared in captivity requires a Federal farming permit from the USFWS. Full details of the stock held and whether it derives from the wild or is captive-born must be submitted with the permit application.

Health regulations are set in each state controlling the slaughter and processing conditions for meat destined for human consumption.

SOURCE OF ANIMALS

The Louisiana ranch stocks are being supplemented with wild-caught animals during their first five to seven years of operation to help them acquire breeding stock and expand their operations. The farms so supplied must comply with specified standards of facilities and planning. Some type of environmental chamber to house juvenile alligators over winter must be available, and farmers must, if required, return to the state live alligators of length $0.9 \mathrm{~m}$ representing 58 of the hatchlings supplied. Periodic inspections are carried out, and farmers must submit annual reports of stock and husbandry records (105). In 1984 Louisiana Rockefeller Refuge supplied a total of 5050 hatchlings to farmers in the state, two-thirds of which derived from wild-collected eggs, and the remainder from eggs laid in captivity (103).

In Florida a programme to evaluate the impact of removing eggs and hatchlings from the wild was initiated in 1981. This relies on a 
helicopter to locate the nests, directing ground teams in airboats to make the collection. Using three boats, up to 1800 eggs have been collected in an 8-hour period. Hatchlings are mostly collected at night from boats. Collection costs in 1984 were about US\$5 an egg and US\$7.32-12.86 a hatchling (96). At least 3217 hatchlings were supplied to farmers in 1984 by this supplement programme (67). BREEDING

In 1980 the five active Florida ranches were collectively producing an average of 2500 hatchlings a year (40). In 19832635 hatchlings were produced from 6 ranches (25). In 1984 breeding took place on 11 ranches, producing a total of 4075 surviving hatchlings. These were derived from a total of 11818 eggs laid, giving a mean hatching succcess rate of 348 (range $0-818$ ). The mean number of eggs per nest was $33.0(67)$.

Only one of the Louisiana ranches was breeding alligators in 1984, when it produced 1800 hatchlings (103).

HUSBANDRY

According to Ashley (40) an area of at least 10 acres ( 4.2 ha) is needed for an alligator farm. Breeding ponds have to be constructed, and wells and pumps adequate to maintain water levels are essential. Concrete rearing pools capable of housing 500 to 1000 alligators of each age class would also have to be constructed. Storage facilities, freezers, coolers, food preparation areas, and skinning and handing areas are also needed.

FINANCES

Running costs for an alligator ranch were estimated in 1980 to total between US $\$ 50000$ and US $\$ 200$ 000 over the first three years $(40)$.

Based on average values of US\$49.21 a linear metre for skins and US\$11.02 $\mathrm{kg}^{-1}$ for meat, farmed animals were worth about US\$200-300 at slaughter in 1984. The costs of raising a hatchling to this size were estimated to be US\$75-100 which, assuming a $90 \%$ survival rate, gave a profit of US\$125 per animal. Very large wild-killed animals of $3.5 \mathrm{~m}$ have raised over US\$1000 each (96). Ashley (41) gave a value in 1981 of US\$355 for each animal, comprising US\$170 for a $17^{\circ}(43-\mathrm{cm})$ belly-width hide and US\$175 for 25 lb of meat (US\$15.4 $\mathrm{kg}^{-1}$ ). 


\section{Loui siana}

NAME OP OPERATION

Rockefeller Wildlife Refuge, captive propagation project

Rockefeller Refuge, Grand Chenier, Louisiana.

Operated by: Louisiana Department of Wildife and Fisheries.

DATE OP ESTABLISHMENT

In 1959 the Louisiana Department of Wildlife and Fisheries initiated an alligator research programme involving Alligator mississippiensis, in two parts:

i) Field studies on life history:

ii) a culture programme incorporating the facts derived from the field study (considering reproductive activity, stocking density, food requirements and social order).

The aim of the programme was to demonstrate the feasibility of raising alligators in captivity (104).

The Louisiana Department of Wildife and Fisheries controls all alligator harvest and farming activities in the state. The Rockefeller Refuge maintains incubation facilities to supply hatchlings to farmers. In 1984 two-thirds of the hatchlings supplied to farmers in the state derived from wild-collected eggs and one third from eggs laid at the Refuge (103).

In 1976 an Alligator sinensis propagation programme was begun (107). SPECIES AND NUMBERS

A. mississippiensis: about 200 broodstock were kept in 1978 (105). (44).

A. sinensis: this operation is based on three mature alligators

\section{PRODUCTION AND TRADE}

The operation is a conservation project and does not produce animals for trade (107). It does, however, supply the hatchlings from wild-collected, artificially incubated eggs to farmers. In 1984 a total of 5050 hatchlings were supplied to 9 farmers (103). The A. sinensis offspring produced have been transferred to the New York Zoological Park and the Texas Zoological Park at Houston (45). SOURCE OP ANIMALS

A. mississippiensis: This operation was based on wild-caught stock and eggs. The eggs collected from the wild within 24 hours of being laid or after the 4 th week of incubation produced the greatest success in the farm-incubation (104).

A. sinensis: All of the animals were obtained from captive sources. The original four adult alligators were from the New York Zoological Park and the U.S. National Zoological Park (107). BREEDING

A. mississippiensis: The first farming efforts involved capturing wild alligators and housing then in large breeding ponds. A stocking rate of one male and one female in each pen ( 0.4 ha) produced successful nesting. Attempts to keep several females with one male resulted in fighting and mortality. Subsequent improvements to the pen design to mimic natural conditions allowed higher stocking rates. Multiple nesting of wild adult females was achieved only after small isolation ponds were added to the breeding enclosures (104).

Use of wild-caught adults as breeders proved impractical because they were found to require more space than animals reared in captivity: but these animals did provide a source of eggs which later formed the 
basis for future breeding stock for a commercially acceptable breeding programme (107).

Age at first nesting, for alligators raised in chambers for three years then transferred to outside pens, was 5 years 10 months compared to 9 years 10 months for wild animals, but reproductive success may not be comparable until the captive-reared animals reach 10 years. The fecundity, fertility and hatching success all increased with age. By the fourth year of breeding the clutch size was approaching 39 eggs, the average for wild nests. Egg fertility of cultured stock averaged only 478 over three years, compared with $87.5 \%$ for wild-caught animals reared in pens. Hatchability was also lower at 448 compared to 588 for wild-caught animals (107).

Eggs were incubated at $29-33^{\circ} \mathrm{C}$ in trays, supported over water, completely enclosed in natural nesting materials to aid degradation of the eggshell (104). Hatching success was found to be best at a temperature of $31-31.7^{\circ} \mathrm{C}(105)$.

A. sinensis: The operation had some trouble in producing offspring at first but after a change in the diet, has had some success. In 1977 one hatchling was produced, however it died within six weeks. In 1979 four young were successfully raised and in 1980, 24 were raised. over this period the hatching success rate works out to be approximately 50 \% (45). HUSBANDRY

Wild-caught adults were found to require 10 times more space than captive-reared animals. Stocking rates for captive-reared animals ranged from 12-46 adults 0.4 ha-1. Juveniles up to three years of age were kept in environmental chambers maintained at $29-32^{\circ} \mathrm{C}$. Stocking densities were held at $10 \mathrm{~m}^{-2}$ for the first year and were then reduced to $3.3 \mathrm{~m}^{-2}$ for older animals (107).

The feeding rate was 258 of body weight a week for the first year reducing to 188 by the end of the third year. The alligators were fed on fish (Micropogon undulatus) or nutria (Myocastor coypus). The nutria-fed animals were $20 z$ heavier and $3 \%$ longer on average than the fish-fed animals, at the end of the study. Behavioural differences were also observed, the nutria-fed animals being more active and aggressive. On a fish diet 49.58 of the dry weight of food fed was converted to body weight over a 33-month period. The feeding rate of adults in outside pens was approximately $6-78$ of body weight a week (104).

Mortality of hatched animals was less than $5 \%$ for the three-year study (104). PINANCES

In 1973-75 it was estimated that it cost us\$20 to raise one alligator to an age of 33 months. This included all running costs, but excluded labour and capital outlay (107).

The A. sinensis project is financed by the New York zoological Society (107).

RESEARCH AND PUBLICATIONS

Researchers who have worked at Rockefeller Refuge include M.J.W. Ferguson, from Manchester University, and V. Lance from Tourlane University, New orleans.

Results from the operation have been published in a number of articles including those used as references here. 


\section{OTHER INFORMATION}

The A. sinensis project was initiated in response to the decline of the species in the wild and began with a pooling of adult specimens already in the USA for propagation purposes. The Rockefeller Refuge was chosen as the site for the captive-breeding project as this was seen to be the closest possible substitute for the animals natural habitat available in the USA. Production of offspring from the operation is hoped to provide a source of animals for the captive population (45).

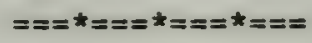

NAME OP OPERATION

Cocodrie Farms

9034 S. Vignes

Baton Rouge,

LA. 70817.

Operated by: D.R. Keller.

DATE OF ESTABLISHMENT (109).

The operation was established in 1977 and became commercial in 1980

\section{SPECIES AND NUMBERS}

Stock at 31 December 1983:

A. mississippiensis: 400 less than $2 \mathrm{ft}(0.61 \mathrm{~m})$

325 between $2 \mathrm{ft}$ and $3 \mathrm{ft}(0.91 \mathrm{~m})$

125 between $3 \mathrm{ft}$ and $4 \mathrm{ft}(1.22 \mathrm{~m})$

140 over $4 \mathrm{ft}$, including 9 breeding males and 33 breeding females

TOTAL

990

(136)

A. mississippiensis: in 1984 stock held before the harvest was 1215 immature and 42 adults (103).

PRODUCTION AND TRADE

The following numbers of skins have been produced on the ranch:

\begin{tabular}{cc} 
Year & Skins produced \\
\hline 1980 & 225 \\
1981 & 250 \\
1982 & 200 \\
1983 & 161 \\
1984 & 200
\end{tabular}

Trade destination

USA and Japan (109)

Japan (109)

USA and Japan (109)

? (136)

? (103)

All skins produced are tagged according to regulations set by the Louisiana Department of Wildlife and Pisheries so they may be distinguished as being from captive-raised animals (109).

Animals are also being kept for breeding purposes. SOURCE OP ANIMALS

All ranch stock has been obtained from the Louisiana Department of Wildlife as juvenile animals which are raised at the Louisiana Department of Wildlife Rockefeller Wildlife Refuge, Grand Chenier, Louisiana (110). Numbers are as follows: 


$\begin{array}{ll}\frac{\text { Year }}{1980} & \text { Numbers of animals } \\ 1981 & 250 \\ 1982 & 375 \\ 1983 & 350(109) \\ 1984 & 400(136) \\ & 500(103)\end{array}$

BREEDING

In 1983 and 1984 a total of 42 five-year-old alligators were being kept to establish a breeding programme. As these animals mature and begin to breed successfully the ranch should become self-sustaining with regard to stock (110). During 1983 these animals first attempted nesting. Four clutches comprising 113 eggs were laid, from which 14 young hatched $(136)$.

BUSBANDRY

The adult animals are kept in a 1.5-acre (0.62-ha) 'natural habitat enclosure enclosed by a 6 ft $(1.83-\mathrm{m})$ chain-link fence. The juveniles are kept in completely enclosed heated chambers measuring $10 \mathrm{ft} \times 32 \mathrm{ft}(3.05 \mathrm{~m} \times 9.75 \mathrm{~m})$, with drains and a fresh water source (109).

The alligators are fed mainly on non-oily saltwater fish but also on red meat procured during the local trapping season (110).

RINANCES

The operation is privately financed and was not self-financing in 1983 (109).

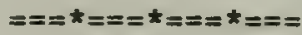

\section{NAME OF OPERATION}

Sauros Inc.

RTI BOX 270A

Bell City

LA 70630 .

Operated by: Emilie D. Perkins.

DATE OR ESTABLISHMENT

The operation was started in June 1979 and became commercial in October 1981.

SPECIES AND NUMBERS

Stock at 31 December 1983:

A. mississippiensis: 1050 less than $2 \mathrm{ft}(0.61 \mathrm{~m})$

987 between $2 \mathrm{ft}$ and $3 \mathrm{ft}(0.91 \mathrm{~m})$

995 between $3 \mathrm{ft}$ and $4 \mathrm{ft}(1.22 \mathrm{~m})$

277 over $4 \mathrm{ft}$

TOTAL

3309

(136)

A. mississippiensis: in 1984 stock held before the harvest totalled 3950, all immature (103).

PRODUCTION AND TRADE

The ranch hopes eventually to produce alligator meat, skins and teeth as commercial products, but as yet no animals have been killed. Alligators are also kept alive for medical research, release to the wild and to provide breeding stock for other alligator ranches. There was no production in 1980. 
U.S.A.

In 1981 and 1982 the ranch produced the following:

\begin{tabular}{|c|c|c|c|}
\hline Year & Product & $\frac{\text { No. of animals }}{\text { involved }}$ & $\frac{\text { Destination of }}{\text { product }}$ \\
\hline 1981 & $\begin{array}{l}\text { Live animals for } \\
\text { medical research. } \\
\text { Live animals for }\end{array}$ & 52 & Canada \& USA \\
\hline 1982 & $\begin{array}{l}\text { breeding stock. } \\
\text { Live animals for }\end{array}$ & 400 & USA \\
\hline & $\begin{array}{l}\text { medical research. } \\
\text { Live animals for }\end{array}$ & 50 & Canada \& USA \\
\hline & breeding stock. & 500 & USA (141) \\
\hline 1983 & & $?$ & \\
\hline 1984 & Skins harvested & 400 & $?(103)$ \\
\hline
\end{tabular}

During the period 1980-82, the following live alligators were released in Louisiana:

\begin{tabular}{llc} 
Year & Age of animals & Numbers of animals \\
\cline { 3 - 3 } 1980 & $\frac{\text { released }}{2}$ years & $\frac{\text { released }}{35}$ \\
1981 & 2 years & 50 \\
1982 & 1 year & 100 \\
& 2 years & $50(141)$ \\
1984 & $?$ & $50(103)$
\end{tabular}

\section{SOURCE OP AMIMALS}

Between 1980 and 1982 all stock was obtained from the Louisiana Department of Wildlife and Fisheries. This stock was captive-bred from animals which had themselves been "bred in captivity" (141). The numbers obtained are as follows:

$\begin{array}{ll}\frac{\text { Year }}{1980} & \text { No. of animals } \\ 1981 & 700 \\ 1982 & 1000 \\ 1983 & 1000(141) \\ 1984 & 1050(136)\end{array}$

\section{BREEDING}

Breeding stock is apparently being built up on the ranch, but as yet all the stock is too young to breed.

\section{HUSBANDRY}

The stock is kept in fibreglass tanks in heated buildings until three years old and is then kept in fenced outdoor ponds designed for breeding. The alligators are fed on the waste products of the local fur trapping and fishing industries (141).

\section{FINANCES}

The operation is privately financed and is not yet self-financing. RESEARCH AND PUBLICATIONS

Breeding results will be published after the breeding programme has been established.

Research work is carried out by the Louisiana Department of Wildife and Fisheries. 
NAME OF OPERATION

Operated by: George Bartmess.

DATE OP ESTABLISHMENT

The first hatchlings were obtained in 1984 (103). SPECIES AND NUMBERS

A. mississippiensis: 500 imnature in 1984 (103). SOURCE OR ANIMALS (103).

500 hatchlings were obtained from the Rockefeller Refuge in 1984

PRODUCTION AND TRADE

No animals were old enough to harvest skins in 1984 (103).

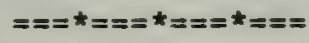

NAME OR OPERATION

Louisiana Land and Exploration.

DATE OR ESTABLISHMENT

The first hatchlings were obtained in 1984 (103). SPECIES AND NUMBERS

SOURCE OF ANIMALS

500 hatchlings were obtained from the Rockefeller Refuge in 1984 (103).

PRODUCTION AND TRADE

No animals were old enough to harvest skins in 1984 (103).

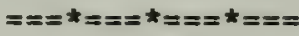

NAME OF OPERATION

10555 Barbara Drive

Baton Rouge

LA 70130.

Operated by: Steele B. McAndrews. SPECIES AND NUMBERS

Stock at 31 December 1983:

A. mississippiensis: 995 less than $2 \mathrm{ft}(0.61 \mathrm{~m})$

125 between $2 \mathrm{ft}$ and $3 \mathrm{ft}(0.91 \mathrm{~m})$

332 between $3 \mathrm{ft}$ and $4 \mathrm{ft}(1.22 \mathrm{~m})$

319 over $4 \mathrm{ft}$

TOTAL $\quad 1771$

In 1984 the stock before the harvest was reported to be 1772 immature (103).

SOURCE OR ANIMALS

1000 hatchlings were obtained from the Rockefeller Refuge in 1984 (103).

PRODUCTION AND TRADE

105 skins were harvested in 1984 (103).

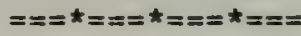

NAME OF OPERATION

Operated by: Robert Ferrington. 


\section{DATE OF ESTABLISHMENT}

The first hatchlings were obtained in 1984 (103). SPECIES AND NUMBERS

SOURCE OF ANIMALS (103).

500 hatchlings were obtained from the Rockefeller Refuge in 1984

PRODUCTION AND TRADE

No animals were old enough to harvest skins in 1984 (103).

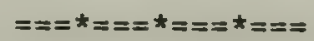

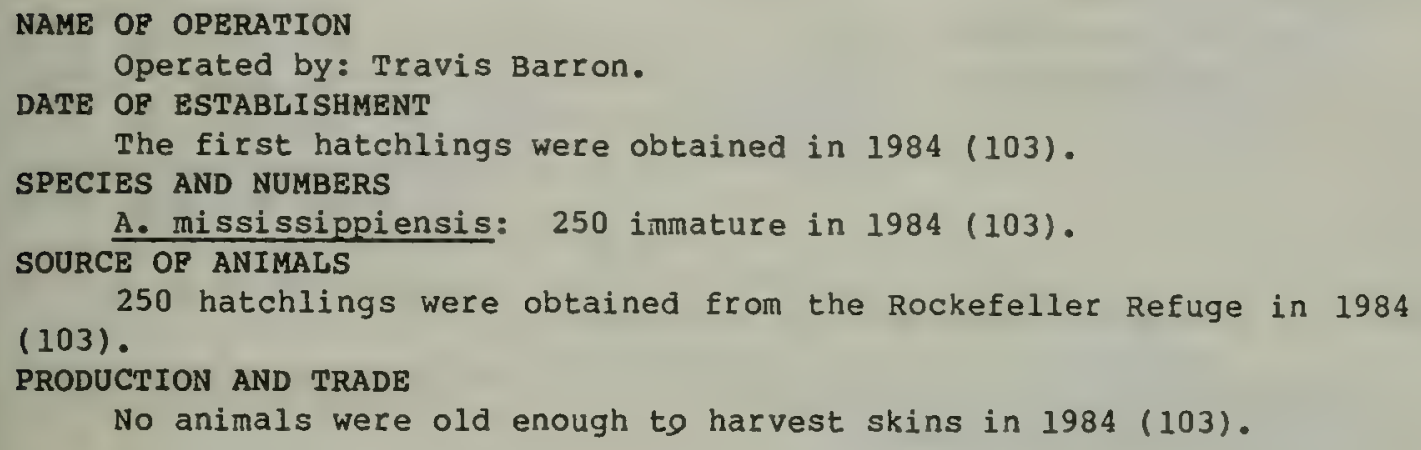

The addresses of 10 other alligator breeders in 1983 are given below. The first five are exhibitors and the remaining five non-commercial, merely keeping alligators as a hobby (103):

1. City of Alexandria Zoological Park, P.O. Box 71, Alexandria, LA 71301.

2. Greater Baton Rouge Zoo, P.O. Box 60, Baker, LA 70704.

3. Audubon Park Commission, P.O. Box 4327, New Orleans, LA 70178.

4. Snake Farm, P.0. Box 96, LaPlace, LA 70068.

5. La Purchase Gardens and Zoo, P.O. Box 123, Monroe, LA 71201.

6. John Paul Crain, P.O. Box 118, Grand Chenier, LA 70643.

7. Norman Perrilloux, 700 Glockner Ct., Mandeville, LA 70448.

8. Ernest Lile Jr., Star Route A, Box 411, Franklin, LA 70538.

9. Hazel Rottman, Star Route Box 206-A, Ponchatoula, LA 70454.

10. Ernest Winbourne, Gator, Inc., 4616 Beau Lac Lane, Metairie, LA 70001. 


\section{Florida}

NAME OR OPERATION

Gator Jungle

26205 Hy 50

PO Box 209

Christmas

Florida 32709.

Operated by: H.W. Brooks.

DATE OP ESTABLISHMENT

The operation was established and became commercial in 1970. SPECIES AND NUMBERS

Stock at 31 December 1983:

A. mississippiensis: 500 less than $2 \mathrm{ft}(0.61 \mathrm{~m})$

600 between $2 \mathrm{ft}$ and $3 \mathrm{ft}(0.91 \mathrm{~m})$

450 between $3 \mathrm{ft}$ and $4 \mathrm{ft}(1.22 \mathrm{~m})$

1970 over $4 \mathrm{ft}$, including 280 breeding males and 200 breeding females

TOTAL $\quad 3520$

(136)

The total stock at 31 December 1984 was 3947 A. mississippiensis and 15 Crocodylus niloticus (67).

\section{PRODUCTION AND TRADE}

The alligators are reared for their skins and meat. Some stock is being reared for breeding purposes.

Skins entering trade, produced on the ranch, are marked by means of tags attached to the hide so indicating that the hide is of ranched origin. Alligator meat produced on the ranch is packaged in boxes marked with seals.

No skins were sold in 1983 (136) or 1984 (67). SOURCE OP ANIMALS

A total of 200 juvenile alligators were taken from the wild in 1981 (62). A further 200 juveniles were acquired from the Florida Game and Freshwater Fish Commission in 1983 (136) and 500 in 1984 (67). BREEDING

Breeding has occurred as follows:

$\begin{array}{lcc}\text { Year } & \text { Number Bred in } & \text { Number Survived } \\ 1980 & \frac{\text { Captivity }}{861} & \frac{30 \text { Days }}{860} \\ 1981 & 688 & 681 \\ 1982 & 300 & 280(62) \\ 1983 & 191 & 180(136) \\ 1984 & 147 & ?(67)\end{array}$

A total of 21 clutches of eggs were laid in 1983, comprising 800 eggs (136). 657 eggs were laid in 1984 (67). HUSBANDRY PINANCES

The stock is kept in five lakes and ponds, and 45 concrete tanks.

The operation is privately financed. 


\section{RESEARCH AND PUBLICATIONS}

Research is carried out by the Florida Alligator Farmers Association and the University of Florida. The results of the operation are published $(62)$.

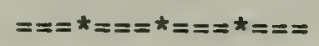

\section{NAME OF OPERATION}

CST Gator Farm

P.O. Drawer 1208

Keystone Heights

Florida 32656.

Operated by: Don R. Morgan.

DATE OP ESTABLISHMENT

The operation was established in June 1980, and was planned to be commercial by September 1984 .

\section{SPECIES AND NUMBERS}

Stock at 31 December 1983:

A. mississippiensis: 988 less than 2 ft $(0.61 \mathrm{~m})$

114 between $2 \mathrm{ft}$ and $3 \mathrm{ft}(0.91 \mathrm{~m})$

176 between $3 \mathrm{ft}$ and $4 \mathrm{ft}(1.22 \mathrm{~m})$

500 over $4 \mathrm{ft}$, including 72 breeding males and 157 breeding females

\section{TOTAL 1178}

2406 alligators were held on 31 December 1984 (67). PRODUCTION AND TRADE

It is intended that the operation will produce meat and skins as well as animals for release to the wild (129).

This farm is allowed to harvest skins but no permit was applied for in 1983 and no sales took place (25). 42 hides were sold in 1984 (67).

\section{SOURCE OP ANIMALS}

Alligators have been obtained from the wild within the state of Florida as follows:

$\begin{array}{ccc}\text { Year } & \text { Number obtained } & \frac{\text { Number survived }}{30 \text { days }} \\ 1981 & 1000 & \frac{995}{740(129)} \\ 1982 & 800 & 988(25) \\ 1983 & 1000 & 506(67)\end{array}$

Capture is regulated by the Florida Game and Fish Department.

275 animals were obtained in 1980 from other alligator ranches (129).

\section{BREEDING}

In 198215 young were bred in captivity and 150 wild-collected eggs were hatched. The number of hatchlings to survive to 30 days from the wild eggs was 148 , mortality just over 18 (129).

In 198313 clutches of eggs were laid with a total of 205 eggs, of which only one hatched (25).

In 198435 clutches were laid with a total of 1105 eggs, of which 122 hatched $(67)$. 


\section{HUSBANDRY}

The alligators are kept in an environmentally controlled concrete building, and also in lakes. They are fed all year (129). EINANCES (129).

The operation is privately financed and is not yet self-financing RESEARCH AND PUBLICATIONS

Dr Paul Cardeilhac carries out research at the operation (129).

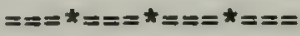

\section{NAME OP OPERATION}

\section{Froehlich's Gator Country}

26256 E. Hwy 50

Christmas

FL 32709.

Operated by: Ed Froehlich.

This farm moved from 8900 W Lake Park Road, Lake Park, FL 33401 to Christmas in 1983 (186).

SPECIES AND NUMBERS

Stock at 31 December 1983:

A. mississippiensis: 2000 less than $2 \mathrm{ft}(0.61 \mathrm{~m})$

1050 between $2 \mathrm{ft}$ and $3 \mathrm{ft}(0.91 \mathrm{~m})$

1500 between $3 \mathrm{ft}$ and $4 \mathrm{ft}(1.22 \mathrm{~m})$

1000 over $4 \mathrm{ft}$, including 68 breeding males and 122 breeding females

TOTAL 5550

The total stock at 31 December 1984 was 3845 alligators (67). PRODUCTION AND TRADE

The farm is allowed to harvest skins but the permit to sell skins was not renewed in 1983 as no request was received. A total of 1031 live alligators were sold during 1983, 996 juveniles and 35 breeding stock (25). No skins were sold in 1984 (67).

BREEDING

1389 eggs were laid in 1983 in a total of 46 clutches. From these 1053 hatched, of which 1000 survived until 31 December 1983 (25).

At Lake Park the broodstock was kept in two natural ponds, several acres in size. In 198040 nests were laid, from which it was hoped to hatch 800 young at an average hatching rate of $65 \%$. Eggs are removed from the nests and incubated artificially in trays containing decomposing vegetation (30).

HUSBANDRY

At Lake Park hatchlings up to one year old were reared in enclosed chambers measuring $5 \mathrm{ft} \times 6 \mathrm{ft} \times 14$ in $11.52 \mathrm{~m} \times 1.83 \mathrm{~m} \times$ $0.36 \mathrm{~m})$ with 100 in each. 100 two-year-olds were reared in each open pen measuring $6 \mathrm{ft} \times 12 \mathrm{ft}(1.83 \mathrm{~m} \times 3.66 \mathrm{~m})$, and 3 - to 4-year-olds are kept in larger pens, measuring $20 \mathrm{ft} \times 20 \mathrm{ft}(6.10 \mathrm{~m})$, again with 100 in each. Alligators reared in these pens were found to be more easy to manage than those reared in natural pens $(30)$.

It is not known what facilities are available at the new site at Christmas.

Food is mostly mixed saltwater fish and chicken necks. Breeding females are given vitamin supplements $(30)$. 


\section{PINANCES}

In 1980 skins were selling at about us\$7 a belly inch $\left(\$ 2.76 \mathrm{~cm}^{-1}\right)$, and the meat, which was supplied to local gourmet restaurants, at US\$6 $1 \mathrm{~b}^{-1}\left(\$ 13.20 \mathrm{~kg}^{-1}\right)$. A 6 -ft $(1.83-\mathrm{m})$ alligator weighs about $80 \mathrm{lb}(36 \mathrm{~kg})$, half of which is meat. This therefore fetched twice the value of the skin $(30)$.

OTHER INFORMATION

Turtles (Trionyx spp.) were also being bred for the pet trade, hatchlings fetching US $\$ 2$ each $(30)$.

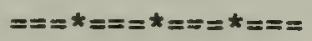

\section{NAME OF OPERATION}

Rt. 1, BOX 340

Bell

FL 32619.

Operated by: Joel w. Smith.

SPECIES AND NUMBERS

Stock at 31 December 1983:

A. mississippiensis: 597 less than 2 ft $(0.61 \mathrm{~m})$

480 between $2 \mathrm{ft}$ and $3 \mathrm{ft}(0.91 \mathrm{~m})$

542 between $3 \mathrm{ft}$ and $4 \mathrm{ft}(1.22 \mathrm{~m})$

2251 over $4 \mathrm{ft}$, including 158 breeding males and 494 breeding females

\section{TOTAL}

3870

(136)

Total stock at 31 December 1984 was 4282 alligators (67). SOURCE OF ANIMALS

No animals were acquired from captive sources during 1983 (25). PRODUCTION AND TRADE

118 skins were sold in 1983 (136) and 540 in 1984 (67). BREEDING

The farm also sells alligator meat (166).

2104 eggs were laid in 1983 in a total of 57 clutches. From these 670 hatched, of which 665 survived until 31 December 1983 (136).

In 1984, 94 nests were laid, totalling 2777 eggs, from which 1023 hatchlings were produced (67).

OTHER INFORMATION

A few freshwater turtles are also kept at the farm (166).

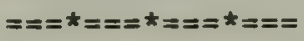

NAME OF OPERATION

Hunt's Alligator Breeding

Route 1, Box 25

Gator Farm Road

Bushnell

FL 33513.

Operated by: Clyde Hunt. 


\section{SPECIES AND NUMBERS}

Stock at 31 December 1983:

A. mississippiensis: 1060 less than $2 \mathrm{ft}(0.61 \mathrm{~m})$

243 between $2 \mathrm{ft}$ and $3 \mathrm{ft}(0.91 \mathrm{~m})$

705 between $3 \mathrm{ft}$ and $4 \mathrm{ft}(1.22 \mathrm{~m})$

1331 over $4 \mathrm{ft}$, including 113 breeding males and 178 breeding females

TOTAL

3339

Total stock at 31 December 1984 was 4026 alligators (67). SOURCE OF ANIMALS

None during 1983 (25).

PRODUCTION AND TRADE

65 skins were sold in 1983 (25) and 78 in 1984 (67). BREEDING

2545 eggs were laid in 1983 in a total of 65 clutches. From these 768 hatched, of which 755 survived until 31 December 1983 (25).

In 1984, 49 clutches, totalling 2121 eggs were laid, from which 717 hatchlings survived (67).

All offspring are captive-bred and no eggs or hatchlings are taken from the wild (186).

NAME OF OPERATION

Godwin's Gatorland, Inc.

Hwy 441 North

Kissimmee

FL 32741 .

Operated by: Frank Godwin.

(The US Fish and Wildlife Service supplied a different address for this operation in 1985: Gatorland Zoo, 14501 S. Orange Blossom Trail, orlando, FL 32821).

SPECIES AND NUMBERS

Stock at 31 December 1983:

A. mississippiensis: 996 less than $2 \mathrm{ft}(0.61 \mathrm{~m})$

777 between $2 \mathrm{ft}$ and $3 \mathrm{ft}(0.91 \mathrm{~m})$

857 between $3 \mathrm{ft}$ and $4 \mathrm{ft}(1.22 \mathrm{~m})$

90 over $4 \mathrm{ft}$

+ approximately 1000 breeding animals

TOTAL $\quad 3720$

At 31 December 1984 the farm held a total of:

4181 A. mississippiensis

36 Crocodylus acutus

23 Caiman crocodilus

1 Crocodylus porosus

1 Crocodylus moreletii (67).

SOURCE OF ANIMALS

952 young were supplied by the Florida supplement programme in $1983(25)$ and 788 in 1984 (67). 


\section{PRODUCTION AND TRADE}

No skins were sold in 1983. The farm is allowed to harvest skins but did not request a permit in 1983 (25). 78 hides were sold in 1984 (67). BREEDING

1241 eggs were laid in 1983 in a total of 47 clutches. From these 55 hatched $(25)$.

In 1984, 35 nests, totalling 1074 eggs were laid, from which 238 hatchlings survived (67).

gUSBANDRY

The breeding stock is kept in one large open pond, making an accurate census impossible (25).

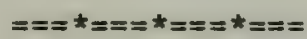

J. \& M. Game Farm

PO Box 24

Kirby Thompson Road

Palmdale

FL 33935.

Operated by: James L. and Maduine Posey.

DATE OF ESTABLISHMENT

The farm was established prior to 1983

SPECIES AND NUMBERS

Stock at 31 December 1983:

A. mississippiensis: 1 less than $1 \mathrm{ft}(0.30 \mathrm{~m})$

57 between $1 \mathrm{ft}$ and $2 \mathrm{ft}(0.61 \mathrm{~m})$

22 between $2 \mathrm{ft}$ and $4 \mathrm{ft}(1.22 \mathrm{~m})$

47 between $4 \mathrm{ft}$ and $6 \mathrm{ft}(1.83 \mathrm{~m})$

16 over $8 \mathrm{ft}(2.44 \mathrm{~m})$

TOTAL

143

Total stock at 31 December 1984 was 367 alligators (67). PRODUCTION AND TRADE

No skins were sold in 1983. The farm has no permit to harvest skins (25).

BREEDING

252 eggs were laid in 1983 in a total of 6 clutches. From these 58 hatched of which all were surviving on 31 December (136).

In 1984, 7 nests were laid, totalling 277 eggs, from which 224 hatchlings survived (67).

BUSBANDRY

The breeding stock is kept in one large open pond, having an area of about $0.5 \mathrm{ha}$. There is a separate 1-ha rearing enclosure with a similar-sized pond.

An incubator constructed from a converted freezer truck is also present (25). 
U.S.A.

NAME OF OPERATION

Limestone Farms, Inc.

1419 Taylor Road

Brandon

FL 33511.

Operated by: John W. Evans \& Mr Davis.

DATE OP ESTABLISHMENT

The farm was described as "new" in 1984 (25). SPECIES AND NUMBERS

Stock at 31 December 1983:

A. mississippiensis: 91 less than $2 \mathrm{ft}(0.61 \mathrm{~m})$

34 between $2 \mathrm{ft}$ and $3 \mathrm{ft}(0.91 \mathrm{~m})$

0 over $3 \mathrm{ft}$

TOTAL

125

Total stock at 31 December 1984 was 124 alligators (67). SOURCE OR ANIMALS

All the animals were obtained from the savage Alligator Farm during 1983 (25).

PRODUCTION AND TRADE (25).

No permit to harvest skins was issued in 1983 as the farm was new

BRBBDING

None reported in 1983 (25) or 1984 (67).

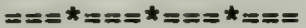

NAME OF OPERATION

357 S. Orange street

Sebring

FL 33807.

Operated by: Steve Kackley.

DATE OP BSTABLISHMENT

The farm was described as "new" in 1984 (25). SPECIES AND NUMBERS

Stock at 31 December 1983:

A. mississippiensis: 292 less than $2 \mathrm{ft}(0.61 \mathrm{~m})$

116 over $6 \mathrm{ft}(1.83 \mathrm{~m})$

TOTAL $\quad 408$

Total stock at 31 December 1984 was 1074 alligators (67). PRODUCTION AND TRADE (25).

No permit to harvest skins was issued in 1983 as the farm was new BREEDING

41 nests were laid in 1984, totalling 1145 eggs, from which 666 hatchlings survived $(67)$. 
NAME OP OPERATION

Howell Alligator Farm

Route 1, Box 1675

Plant City

FL 33566.

Operated by: John T, Howell.

DATE OF ESTABLISHMENT

The farm was described as "new" in 1984 (25).

SPECIES AND NUMBERS

Stock at 31 December:

A. mississippiensis: 230 in 1983

158 in 1984

(67)

\section{PRODUCTION AND TRADE}

No permit to harvest skins was issued in 1983 as the farm was new (25).

BREEDING

No breeding took place in 1984 (67).

$==ニ *=ニ=*===*==0$

NAME OF OPERATION

Swampy Farms (AKA Hilltop Farms)

PO BOX 818

1107 West Main Street

Avon Park

FL 33825.

Operated by: Lawler M. Wells.

DATE OF ESTABLISHMENT

The farm was described as "new" in 1984 (25).

SPECIES AND NUMBERS

Stock at 30 June 1984:

A. mississippiensis: 172 less than $2 \mathrm{ft}(0.61 \mathrm{~m})$

939 between $2 \mathrm{ft}$ and $4 \mathrm{ft}(1.22 \mathrm{~m})$

713 between $4 \mathrm{ft}$ and $6 \mathrm{ft}(1.83 \mathrm{~m})$

206 between $6 \mathrm{ft}$ and $8 \mathrm{ft}(2.44 \mathrm{~m})$

189 over $8 \mathrm{ft}$

TOTAL

2219

(25)

Total stock at 31 December 1984 was 2689 alligators (67). PRODUCTION AND TRADE

No skins were sold in 1984. No permit to harvest skins was issued as the farm was new (25).

BREEDING

31 nests were laid in 1984, containing 1066 eggs, from which 377 hatchlings survived $(67)$.

$$
==* *==* *=\approx *=\approx=
$$

\section{NAME OP OPERATION}

Circle G Alligator Ranch

Route 3, Box 219

Bushnell

FL 33513.

Operated by: John F. Galvin. 
U.S.A.

DATE OP ESTABLISAMENT

The farm was described as "new" in 1983, and was probably established in April 1982 (83).

SPECIES AND NUMBERS

A. mississippiensis: 59 at 31 December 1984 (67). PRODUCTION AND TRADE

No skins were sold in 1984. No permit to harvest skins was issued as the farm was new (25).

BREEDING

No breeding took place in 1984.

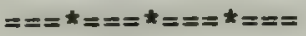

\section{NAME OP OPERATION}

Nelson Fence Co.

Exotic breeders

755 South Little John Road

Inverness

FL 32650.

Operated by: Ron Nelson.

SPECIES AND NUMBERS

Stock at 31 December 1984:

2 Paleosuchus sp.

2 Crocodylus acutus

3 Crocodylus niloticus

1 Crocodylus siamensis

(67). PRODUCTION AND TRADE

No skins were sold in 1984. The farm only intends to breed animals for live sale (25).

BREEDING

No breeding took place in 1984 (67).

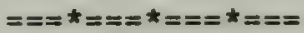

NAME OF OPERATION

Flying " $P$ " Ranch

PO Box 892, Hwy 471 North

Bushnell

FL 33513.

Operated by: George O. Parrot.

DATE OP ESTABLISHMENT

The farm was reported to exist prior to July 1983 (83). SPECIES AND NUMBERS

Stock at 31 December 1983:

A. mississippiensis: 673 less than $2 \mathrm{ft}(0.61 \mathrm{~m})$

0 between $2 \mathrm{ft}$ and $3 \mathrm{ft}(0.91 \mathrm{~m})$

0 between $3 \mathrm{ft}$ and $4 \mathrm{ft}(1.22 \mathrm{~m})$

70 over $4 \mathrm{ft}$, including 19 breeding males and 51 breeding females

TOTAL

743

Total stock at 31 December 1984 was 1256 alligators (67). 


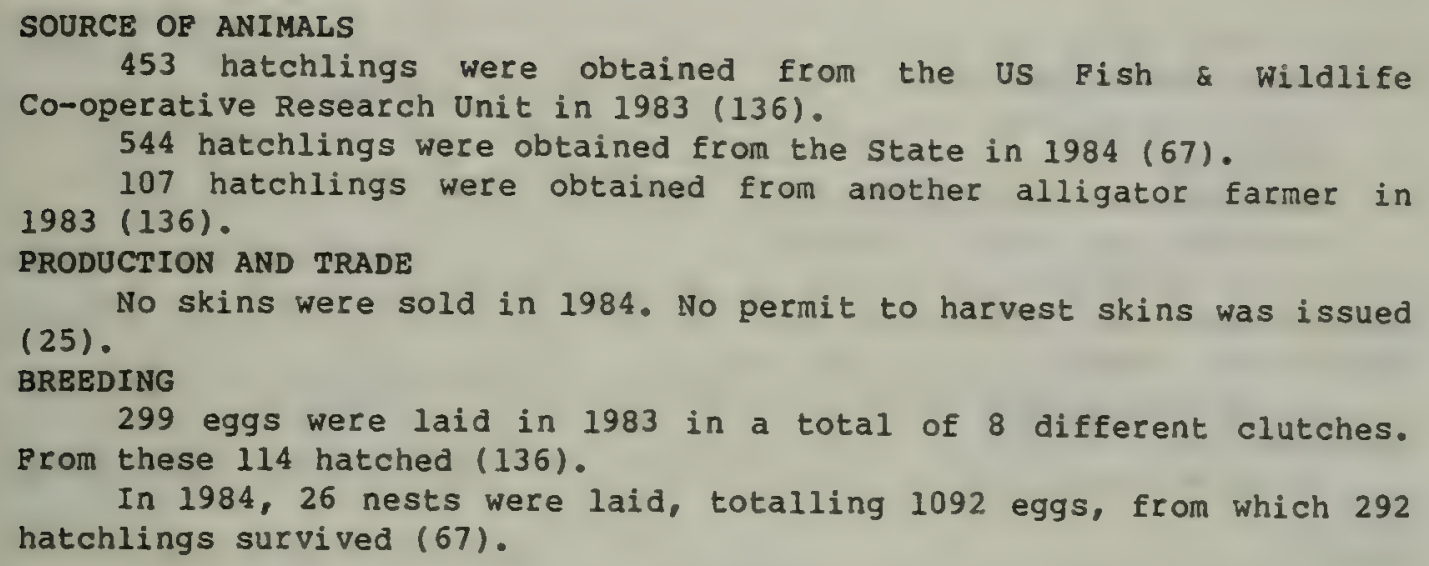

Total stock at 31 December 1984 was 1581 alligators (67). SOURCE OR ANIMALS

175 hatchlings were obtained from the Florida Game \& Fish supplement Programme in 1983 (136) and 879 in 1984 (67). PRODUCTION AND TRADE (25).

No skins were sold in 1984. No permit to harvest skins was issued

\section{BREEDING}

264 egg.s were laid in 1983 in a total of 9 clutches. From these, 144 hatched of which 144 survived until 31 December (136).

In 1984, 16 nests were laid, totalling 369 eggs, from which 213 hatchlings survived (67). 
NAME OP OPBRATION

Gomes Gator Farm

Route 1, Box 484

Riverview

PL 33569.

Operated by: Prank R. Gomes.

DATE OP BSTABLISHMENT

The farm was reported to exist prior to July 1983 (83). SPECIES AND NUMBERS

A. mississippiensis: 53 at 31 December 1984 (67). PRODUCTION AND TRADE

No skins were sold in 1984. No permit to harvest skins was issued (25).

BREEDING

No breeding took place in 1984 (67).

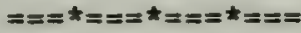

NAME OP OPERATION

Ken's Land Clearing

2460 State Road 17 South

Avon Park

FL 33825 .

Operated by: Ken Geiger.

DATE OP ESTABLISHMENT

The farm was described as "new" in 1984 (25). SPECIES AND NUMBERS

A. mississippiensis: 200 at 31 December 1984 (67). PRODUCTION AND TRADE

No skins were sold in 1984. No permit to harvest skins was issued as the farm was new (25).

BREEDING

No successful breeding took place in 1984, although one nest of 34 eggs was laid (67).

$==$ $*==$ * $=$ = $=$ * $=$

NAME OP OPERATION

Gator Jungle of Plant City

Route 2, Box 884

Plant City

FL 33527.

Operated by: Tracy Howell.

DATE OP ESTABLISHMENT

The farm was described as "new" in 1984 (25). SPECIES AND NUMBERS

A. mississippiensis: 365 at 31 December 1984 (67). PRODUCTION AND TRADE

No skins were sold in 1984. No permit to harvest skins was issued as the farm was new (25).

BREEDING

56 hatchlings were produced in 1984 from 101 eggs (67). 


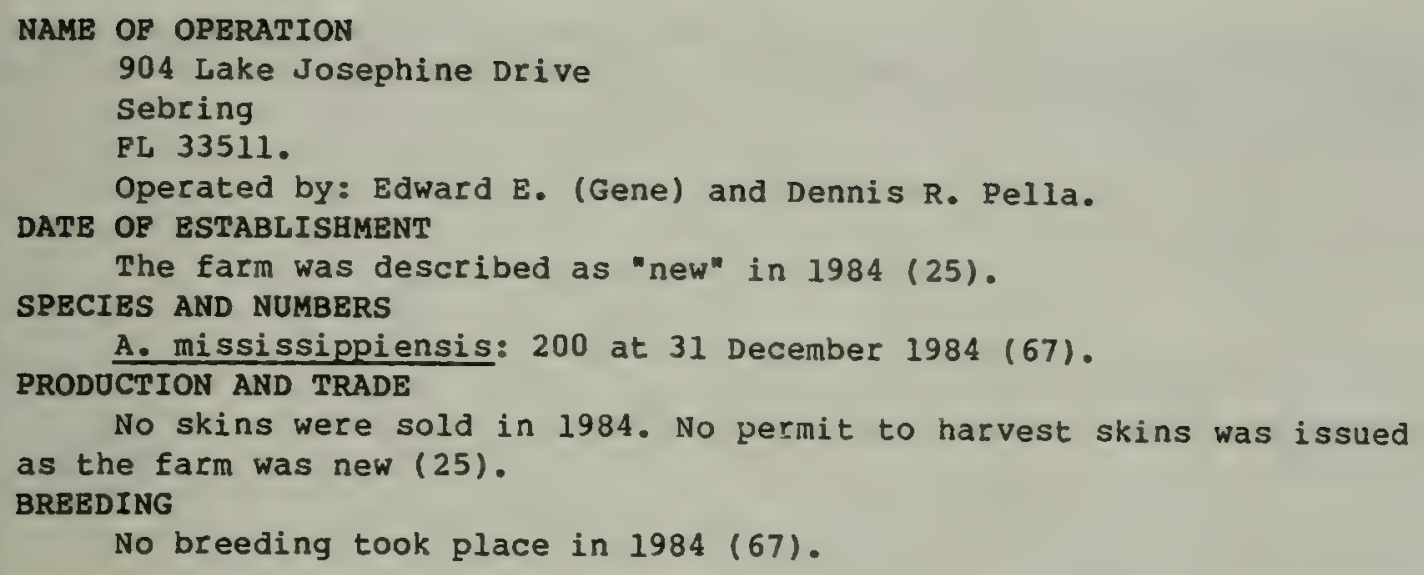

One farm was reported to exist in July 1983, by the Florida Game and Freshwater Fish Commission (83) but not in 1984:

Savage Gator Farm, Route 1, Box 142, Arcadia, FL 33812.

Limestone Farms report having purchased livestock from this farm in 1984 (25).

The address of a further farm was supplied by the US Fish and wildlife service in 1985 (136):

Thomas A. Taylor, Gatorland Alligator Farm, Rt. 3, Box 27B, St Augustine, FL 32084 .

\section{Texas}

The address of one farm was supplied by the US Fish and Wildife Service in 1985 (136):

Warren Lynch, Star Rt. 1, Box 624-A, Rockport, TX 78382. 


\section{URUGUAY}

A project involving the captive breeding of Caiman latirostris for conservation purposes was planned in 1977 (8) but has not so far been implemented (1). 


\section{VENEZUELA}

Following excessive hunting, all crocodilians were protected in Venezuela. However the Ministerio del Ambiente y los Recursos Naturales Renovables (MARNR), encouraged by the recovery of wild populations of Caiman crocodilus, has recently proposed a possible multi-level management scheme for skin exploitation of this species. An experimental scheme allows for a controlled harvest of caimans mainly on private ranches, based on population estimates conducted by MARNR (152). The means by which these estimates are produced and the level of the harvest are under discussion.

It is proposed that the population should receive continued protection outwith the licensed harvest and several measures have been suggested to encourage the wild population. At the lowest level this would involve the protection of nesting areas and ponds from agricultural pressures. More active assistance could be provided by constructing ponds in regions where they normally dry up in the dry season, the relocation of threatened groups of juveniles, and the control or exclusion of predators.

other options under consideration are ranching, either by collecting and incubating caiman eggs and releasing the juveniles, or by rearing them to commercial size in captivity. The MARNR already runs an experimental centre to investigate techniques of captive rearing. As a result of this experience it recommended, in 1982, taking eggs from the nests of wild crocodiles, and incubating them; raising the hatchlings in $1 \mathrm{~m} \times 3 \mathrm{~m}$ tanks, with 100 animals to a tank, for one year; feeding the young on small fish, finely chopped meat and insects, which would be attracted to the tanks at night by bright lights hanging above. After one year the young caiman would be returned to semi-wild conditions in the form of fenced-off natural lakes and rivers where again they would be fed on fish and meat. The animals would be harvested after three years for their skins, the meat being fed back to the younger stock (17).

Two private ranches in the Llanos region, Hato Masaguaral and Hato El Frio, have been keeping Crocodylus intermedius and have succeeded in breeding them. Some hatchlings have been released to the wild, but this is purely a conservation exercise, as the wild population is too low to allow exploitation at present. Experiments have also begun on collecting and incubating eggs of Caiman crocodilus to evaluate the pfofectation folpasing juveniles, on the potential harvest of the wild 
WESTERN SAMOA

According to a newspaper report in 1981, a West German proposed to build a crocodile farm on the island (21). No more has been heard of the proposal, but the Government Director of Agriculture and Forests declared that there was no wildlife farming of any kind in 1983 (156). 


\section{ZAMBIA}

There are up to four crocodile farms in zambia, but only two of these are operating on a large scale. The first was established in 1980.

NAME OR OPERATION

Kariba Crocodile and Fish Farms Ltd

P.O. Box 34284

Lusaka

Zambia.

Director: Mr G.J. Parker.

DATE OF ESTABLISHMENT

1981

SPECIES AND NUMBERS

Crocodylus niloticus: around 2000 crocodiles were held in 1984, consisting of 800 two-year-olds, 800 one-year-olds and 400 hatchlings (139).

The stock later in 1984 was reported to be 2273 animals (176). PRODUCTION AND TRADE

In 1982, 90 farm-raised crocodiles were expected to be ready for marketing by the end of 1983 (18), however no commercial production took place (138). It was hoped that the sale of skins to French tanners would comnence in 1985 (139).

SOURCE OR ANIMALS

All stock has been obtained from the wild. Eggs have been collected in Zambia under Government licence and hatched at the farm. The Government controls the number of eggs allowed to be taken and the areas from which this can be done. They then demand the release of $10 \%$ of the stock after two years (138).

Eggs obtained from the wild and hatching success 1981-82

$\begin{array}{lccccc}\text { Year } & \text { Number of eggs } & \text { Number hatched } & & \text { Hatch rate } \\ 1981 & \frac{\text { obtained }}{1655} & 1417 & 868 & \\ 1982 & 880 & 794 & 908 & \text { (138) }\end{array}$

The quota for the collection of eggs in 1984 was 4000 (176).

The operation hoped to be permitted to catch adult animals for breeding purposes in 1984. The Zambian Government requires the operation to have suitable holding facilities prepared before they will issue licences to capture adult crocodiles (139).

BREEDING

Breeding has not yet commenced on the farm as the rearing stock is still immature (138), however there are plans to acquire a breeding nucleus of 10 females and two males from the wild (176).

BUSBANDRY

The animals are held in concrete enclosures of approximately $60 \%$ land and $40 \%$ water. They are fed on small whole fish, obtained from the fishing aspect of the operation, and some goat meat (138).

The farm was reported to be experiencing difficulties with the water system and hygiene in 1984 (176).

BINANCES

The operation depends upon the commercial fishery run in conjunction with it on Lake Kariba, Zambia, for both income and feed (138). 
Zambia

RESEARCH AND PUBLICATIONS

Research is carried out by Gordon Parker mainly for the Zambian Government. Nesting data are collected for Mr G.B. Kaweche, Chief Research officer of the Zambia National Parks and Wildlife Service, and it is proposed that data on reproductive biology will be collected when breeding starts (138).

OTHER INPORMATION (138).

Eggs are collected from Game Management areas and Open Areas only

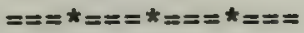

NAME OF OPERATION

The farm is located by Lake Tanganyika.

Director: Mr A. Carr.

DATE OP ESTABLISHMENT

About 1980 (176)

SPECIES AND NUMBERS

C. niloticus: around 500 crocodiles are held, - estimated from photographs seen by $K$. Van Jaarsveldt (183).

PRODUCTION AND TRADE

No skins had been sold by 1984 (176).

OTHER INFORMATION

In 1985 the farm was reported to have serious management problems and to be in danger of being closed down by the Wildlife Authorities (176).

$=ニ *=\approx * *==* *==$

NAME OF OPERATION

Luangwa Crocodile and Safaris

P.O. Box 37542

Lusaka.

Directors: Mr K. Asherwood and Mr C. Beukes.

DATE OF ESTABLISHMENT

1984

SPECIES AND NUMBERS

C. niloticus: it was intended to collect about 5000 eggs to operate along the lines of the farms in Zimbabwe (183).

The target is for a stock of 9000 crocodiles (176). SOURCE OF ANIMALS

The farm had a quota to collect 5000 eggs and 25 adult breeding crocodiles in $1984(176)$.

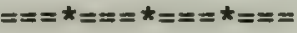

A farm owned by Mr A. Bowyer is reported to exist at siavonga, on Lake Kariba. In 1982 he obtained permission to collect 1000 eggs on the Zambezi (206). The present status is uncertain, and the farm was not mentioned by Tello in 1985 (176). 


\section{ZIMBABWE}

\section{General Information}

Nile crocodiles have been ranched in zimbabwe since 1965; there are now six crocodile ranches in existence there. Three further ranches existed previously but were all short-lived. Binga Ranch, Karoi Ranch and Mini Crocodile Ranch were established at Lake Kariba in 1965, 1966 and 1967 respectively, but all closed within two years (66).

\section{SPECIES AND NUMBERS}

Crocodylus niloticus: In 1984 there were a total of 27704 animals on the ranches comprising 16000 rearing stock, 11466 hatchlings, 52 mature males and 186 mature females (55).

Approximate figures for the total stock on farms in previous years are given below $(66)$ :

\begin{tabular}{lrrr} 
Year & Stock & Year & Stock \\
\cline { 3 - 4 } 1967 & 1400 & 1977 & 9000 \\
1968 & 2400 & 1978 & - \\
1969 & 3700 & 1979 & 15500 \\
1970 & 5000 & 1980 & 20000 \\
1971 & 6000 & 1981 & 20000 \\
1972 & 6600 & 1982 & 24000 \\
1973 & 7300 & 1983 & 28500 \\
1974 & 7100 & & \\
1975 & 9000 & & \\
1976 & - & &
\end{tabular}

\section{PRODUCTION AND TRADE}

In the 1981 season, 2890 skins were produced for export from zimbabwe (179). On projected hatching of juveniles in 1984/85 the potential production in $1987 / 88$ is 13850 skins (55).

Approximately 10-348 of the animals over one year of age are slaughtered each year. Skin sales from farms can be expected to grow at about 228 a year. In 1984 the industry was said to generate us $\$ 334000$ a year in foreign exchange (66).

zimbabwe's annual report to CITES for 1983 reported the following comercial exports of skins and live animals:

$\begin{array}{rll}\text { Quantity } & \text { Product } & \text { Destination } \\ 427 & \text { Live } & \text { South Africa } \\ 66 & \text { Skins } & \text { South Africa } \\ 25 & \text { Skins } & \text { UK } \\ 860 & \text { Skins } & \text { France }\end{array}$

All exports are currently through the Crocodile Farmers Association of Zimbabwe. When the Zimbabwe population of Crocodylus niloticus was on CITES App. I the skins were marketed only in France. However, enquiries about the purchase of products had come from the UK, F.R. Germany, Switzerland, USA, Canada and Japan (179). The population was transferred to Appendix II in 1983 and sales are now also made to other countries.

The skins of animals ranched in zimbabwe are tagged to show their origin and the numbers of the tags on skins exported must correspond 
with the record on the export permit; the records are also kept by the zimbabwe Department of National parks and Wild Life Management. The tags come in two parts which, once clipped together, cannot be reused. Prior to issue the two sections are kept separately, one kept by the Crocodile Farmers' Association and one by the Department. Skins must be tagged on a specified margin which is varied from time to time $(66)$.

\section{SOURCE OF ANIMALS}

Crocodile ranching was experimentally introduced into zimbabwe with the emphasis placed on collecting eggs from good breeding population areas, artificially incubating them and rearing the hatchlings $(40)$. From 1967 to 1973 a total of 22679 eggs were collected and 16679 were hatched, giving a mean hatching success rate of 73.58 (40). From 1979 to 1983 a total of 38077 eggs were collected, hatching with a success of $88.68(66)$.

Eggs are normally collected in early November, 50-60 days after laying, when they may be moved with less danger of damage. Experienced collectors can distinguish between fertile and infertile eggs, and collect only the former. This may explain some of the reported improved hatching percentage. The eggs are incubated in moist vermiculite in styrofoam boxes stored in a temperature-controlled shed at about $32^{\circ} \mathrm{C}$. Hatching usually occurs in late December (66).

The stocks come from "Government egg supplementary programmes" and each ranch is annually designated an egg-collecting area and a number of eggs that may be collected $(180)$ :

$\underline{\text { Egg-collecting }}$

\begin{tabular}{lrrr} 
Station & Current & Increase & Total \\
\cline { 2 - 3 } Binga & $\frac{\text { quota }}{2500}$ & - & 2500 \\
Kariba & 2000 & - & 2000 \\
Rokari & 1000 & 1000 & 2000 \\
Sengwa Mouth & 2000 & 500 & 2500 \\
Spencers Creek & 2500 & - & 2500
\end{tabular}

Captive-breeding stock

\begin{tabular}{lll}
\multicolumn{1}{c}{ Females } & Males \\
$72(40)$ & $15(10)$ \\
$62(40)$ & $20(10)$ \\
$(40)$ & $(10)$ \\
$(40)$ & $(10)$ \\
$94(30)$ & 20
\end{tabular}

(figures in brackets "are from present capture programmes initiated by National Parks and Wild Life Management and should be completed before May 1983. Unbracketed figures are stock on hand currently capable of breeding" in 1982 180) The capture programme will probably not be completed until 1985 (182).

The captive-breeding stock comes from the ranches' own hatched stock or from problem-animal control programmes. Every effort is made by the Department of National Parks and Wildife Management to capture problem animals from the wild, and there are severe and strictly enforced penalties for poaching and unauthorised killings. A maximum of twelve crocodiles a year have been allocated to registered safari hunting operations. The ranches provide a safe repository for wild animals which have genuinely become a menace to humans and livestock (179). 
Zimbabwe

The total numbers of eggs collected from the wild from 1979 to 1983 and the hatching success is given below $(66)$ :

$\begin{array}{lrrrr}\text { Year } & \begin{array}{c}\text { No. } \\ \text { collected }\end{array} & \begin{array}{c}\text { No. } \\ \text { hatched }\end{array} & & \text { Hatching } \\ & & & \text { success } \\ 1979 & 8279 & & 4497 & 85.28 \\ 1980 & 8079 & & 7069 & 87.58 \\ 1981 & 8768 & 7879 & 89.98 \\ 1982 & 10389 & 8943 & 86.18 \\ 1983 & 10908 & 9961 & 91.38\end{array}$

\section{BREEDING}

The ranches had breeding facilities involving 152 crocodiles and a production of 3000 eggs in 1982. The hatching percentage and numbers are expected to increase each year, however, to retain viability it is necessary to supplement the breeding stocks with the collection of eggs from the wild (179).

In 1984 there was a total breeding stock of 186 females which were expected to produce 13440 hatchlings in 1984/85 (55). Initially equal numbers of males and females were kept but this was found to be unnecessary as each male can serve up to 20 females (66).

From 1979 to 1983 a total of 8828 eggs were laid at two farms, which had an average hatching success of $72.78(66)$.

\section{HUSBANDRY}

All five ranches operate under a closed incubation/hatchery construction.

Hatchlings are removed to open pens, are graded by size and condition and are housed in densities calculated to minimise stress. originally earth ponds were used but problems were experienced with burrowing, and now most ponds are of concrete. In the first year of life about 150-200 animals are kept in each pen, comprising two ponds 10-15 $\mathrm{m}$ long by $1.5 \mathrm{~m}$ wide by $60 \mathrm{~cm}$ deep. Later they are moved to larger pens (ca $20 \mathrm{~m}$ by $8 \mathrm{~m}$ ) with 75-100 animals in each. They are initially fed on freshwater sardine known as kapenta (Limnothrissa miodon) and later on elephant meat (supplied under special permit from the Dept. of National Parks and Wild Life Management) to which is added bone meal, vitamins and trace elements (66).

The animals are normally slaughtered at 2-4 years old at a length of $1.5 \mathrm{~m}$, when their belly skin is about $35 \mathrm{~cm}$ wide. Each animal is shot in the head with a short .22 bullet. Eviscerated carcases are fed back to the other crocodiles as no market has been developed for the meat $(66)$.

\section{RINANCES}

A financial analysis reported in 1982 that the average cost per egg was US\$2.49 for those collected from the wild and US\$1.25 for those laid on the farm. It was found that the cost of feeding one male and 10 females was US $\$ 457$ a year, food consumption averaging at 5.68 of the body weight a year $(80)$.

Whitaker et al. reported that lacquered skulls and feet sold as curios for US $\$ 10$ and US\$2.5 respectively. Back skins, for use in belt manufacture, were worth a further US\$20 (204). 


\section{Zimbabwe}

\section{OTHER INPORMATION}

Crocodile farmers in zimbabwe must provide the Department of National Parks and wild Life Management with a monthly return of stock on hand, hatchlings, deaths, killings, eggs collected and hatches. Government policy requires that some suitably-sized crocodiles be made available for reintroduction for conservation purposes. Originally this was set at $10 \%$ of the eggs or hatchlings collected, but this was later reduced to $5 \%(66)$. This availability "is in the form of crocodiles of a size suitable for restocking denuded habitats, augmenting wild populations, research or the meeting of international obligations" (179). No return of stock took place from 1978 to 1984 and the Department of National Parks and wildlife Management has waived its right to its quota for these years (55). A total of 910 animals have been returned to the wild under this scheme, and a further 30 used for research or donated to other countries (66). 
NAME OP OPERATION

Binga Crocodile Farm

P.0.Box 16, Binga, Lake Kariba West.

Operators: K.R. \& A. Van Jaarsveldt.

DATE OP ESTABLISHMENT

The ranch was established in August 1967 and became commercial in 1970 (184).

SPECIES AND NUMBERS

C. niloticus: the ranch on average holds a stock of around 4000 animals but this may increase annually to around 7000 as a result of breeding, before decreasing as stock is slaughtered (181).

Stock held in January 1982 (19)

\begin{tabular}{lr}
\hline Hatchlings & 2137 \\
Slaughter Stock & 3715 \\
Breeding stock & 30 \\
Total & 5882
\end{tabular}

PRODUCTION AND TRADE

Product

Skins

Skins

Skins

Live Animals

$\frac{\text { Date of }}{\text { production }}$
1980
1981
1982
1982

\begin{tabular}{lr} 
Stock held in & December \\
\hline Hatchlings & 1865 \\
Rearing & 3622 \\
Breeding & 33 \\
Total & 5520
\end{tabular}

(68)

\begin{tabular}{|c|c|}
\hline Quantity & Destination \\
\hline 774 & France (184) \\
\hline 1414 & $\begin{array}{l}\text { France and Japan } \\
(184)\end{array}$ \\
\hline 1039 & France (184) \\
\hline Nil & (68) \\
\hline
\end{tabular}

\section{SOURCE OF ANIMALS}

In 1982, 1865 hatchlings were produced from eggs of wild origin. The ranch holds 6 problem animals which have been included as breeding stock in the figures above (68). See also General Information, above.

Stock taken from the wild:

\begin{tabular}{|c|c|c|c|c|}
\hline Date & Adults & Eggs & Country 0 & f origi \\
\hline 1980 & 0 & 2047 & Zimbabwe & \\
\hline 1981 & 0 & 2491 & zimbabwe & \\
\hline 1982 & 6 & 2058 & Zimbabwe & $(184)$ \\
\hline 1983 & - & 2518 & Zimbabwe & $(66)$ \\
\hline
\end{tabular}

Hatching success of the wild-taken eggs:

$\underline{\text { Date }}$

1980

1981

1982

$$
\frac{\text { No. of eggs }}{\text { hatched }}
$$

1789

2145

1865
No. of hatchlings survived

$$
\text { over } 30 \text { days }
$$

1757

2137

$1803 \quad(184)$

\section{BREEDING}

Provision for breeding on the ranch was first made in 1982. A total breeding stock of 33 animals ( 30 females and 3 males) exists; 27 six-year-old ranch-reared crocodiles, and 6 wild-caught animals purchased 
from the National Parks. The breeding stock is held in separate breeding pens (184).

The first breeding occurred on the farm in 1983 when a total of 60 eggs were laid $(66)$.

See also General Information, above. HUSBANDRY

The crocodiles are kept in two types of enclosures:

a) Concrete pools with cement feeding apron and areas of lawn grass, enclosed by brick walls;

b) Natural earth ponds enclosed by sheet metal fencing.

Fresh food is provided to all pools in the form of freshwater sardine and elephant meat (184).

Mortality of animals in excess of one year-old averaged 58 from 1981 to 1983. Hatchling mortality averaged 28.48 over the same period $(66)$.

FINANCES

Private $(68)$.

RESEARCH AND PUBLICATIONS

Research has been carried out by Dr C. Foggin, Veterinary Department, Zimbabwe (184).

$=ニ *=ニ * *=* *==$

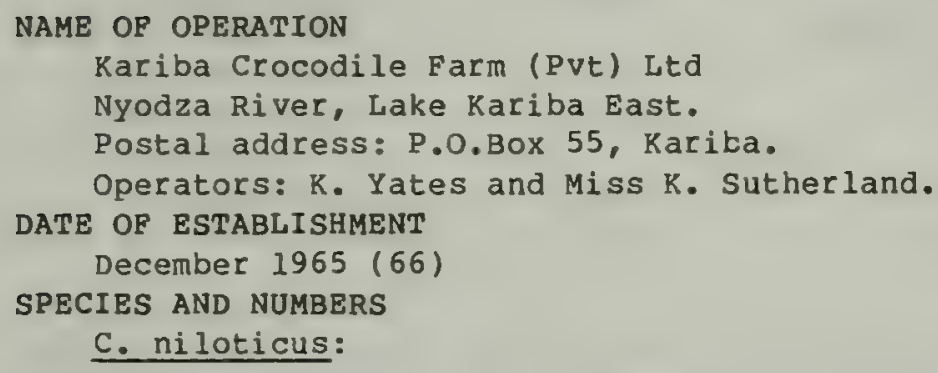

Stock held in January 1982 (19)

Hatchlings 1879

Slaughter stock 3170

Breeding Stock 44

Total 4093

4

PRODUCTION AND TRADE (68)

$\begin{array}{ll}\text { Product } & \frac{\text { Date of }}{\text { production }} \\ \text { Skins } & \frac{1982}{\text { Live Animals: }} \\ \text { yearlings } & 1982 \\ 3 \text { year-olds } & \\ \text { c. } 15 \text { year-olds }\end{array}$

\section{Quantity Destination}

$186 \quad$ France

\begin{tabular}{lr} 
Stock held & in \\
\hline Hatchlings & 1762 \\
Rearing & 3955 \\
Breeding & 41 \\
Total & 4758
\end{tabular}

Total 
SOURCE OF ANIMALS

In December 1982 the ranch held five problem animals which have been included in the breeding stock figures above (68).

Total numbers of eggs collected from the wild were as follows (66):

$\begin{array}{lll}\text { Year } & \text { No. collected } & \frac{\text { Hatching }}{\text { Success }} \\ 1979 & 1323 & \frac{\text { Su.48 }}{89.48} \\ 1980 & 2019 & 82.58 \\ 1981 & 1847 & 91.78 \\ 1982 & 1687 & 76.78 \\ 1983 & 1876 & 97.38\end{array}$

\section{BREEDING}

In December 1982 the ranch held a breeding stock of 41 animals. Of these, 36 were ranch-reared and five were problem animals (68).

Total production of eggs laid on the farm was as follows $(66)$ :

\begin{tabular}{|c|c|c|}
\hline Year & No. Iaid & Hatching \\
\hline & & success \\
\hline 1979 & 565 & 59.88 \\
\hline 1980 & 292 & 82.58 \\
\hline 1981 & 310 & 71.68 \\
\hline 1982 & 602 & 77.48 \\
\hline 1983 & 505 & 95.08 \\
\hline
\end{tabular}

\section{HUSBANDRY}

The animals are kept in enclosures surrounded by either cement blocks or security fencing, with either earth or concrete ponds (68).

Mortality of animals in excess of one year-old averaged 1.48 from 1980 to 1983. Hatchling mortality averaged 30.98 over the same period $(66)$.

PINANCES

Private (68). Entrance fees paid by tourists to view the crocodiles are an important part of the total income. Handicraft and curio shops are supplied by local craftsmen (179).

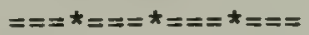

\section{NAME OP OPERATION}

Game and Fishing (Pty) Ltd

P.O.Box 381, Marondera, Bumi River, Lake Kariba.

Operator: S.P. Grobler.

DATE OP ESTABLISHMENT

November 1981

SPECIES AND NUMBERS

\section{C. niloticus:}

Stock held in January 1982 (19)

Hatchlings 997

slaughter stock 0

Breeding stock 0

Total

Stock held in December 1982

(68)

$\begin{array}{lr}\text { Hatchlings } & 1487 \\ \text { Rearing } & 900 \\ \text { Breeding } & 0 \\ \text { Total } & 2387\end{array}$




\section{PRODUCTION AND TRADE}

The crocodiles are being raised for their skins, but by 1983 no crocodile products from the ranch had entered trade (184).

\section{SOURCE OF ANIMALS}

Eggs taken from the wild.

$\begin{array}{lll}\frac{\text { Date }}{1980} & \frac{\text { Eggs }}{0} & \text { Country of origin } \\ 1981 & 1000 & \text { Zimbabwe } \\ 1982 & 2000 & \text { Zimbabwe }(184) \\ 1983 & 1889 & \text { Zimbabwe }(66)\end{array}$

Hatching success of wild-taken eggs.

$\begin{array}{lcrl} & \text { No. of eggs } & \text { No. of hatchling } \\ \frac{n}{1980} & \frac{\text { hatched }}{0} & \text { over } 30 \text { days } \\ 1981 & 980 & 960 & \\ 1982 & 1927 & 1846 & (184) \\ 1983 & 1791 & & (66)\end{array}$
BREEDING

See also General Information, above.

Some of the animals being reared are to be used for breeding purposes.

\section{HUSBANDRY}

The animals are kept in enclosures with concrete ponds (68) surrounded by $4 \mathrm{ft}(1.2 \mathrm{~m})$ high concrete walls (184). They are fed on fish and game meat (184).

Mortality of animals in excess of one year-old averaged $2.0 \%$ from 1982 to 1983. Hatchling mortality averaged 16.48 over the same period (66).

\section{PINANCES}

Private $(68)$.

\section{RESEARCH AND PUBLICATIONS}

Research has been carried out by Dr C. Foggin, Veterinary Department, Zimbabwe and R. Taylor (184).

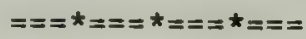

\section{NAME OF OPERATION}

Spencer's Creek Crocodile Ranch (Pvt) Ltd

P.O.Box 18, Zambezi River, Victoria Falls.

Operators: R. Gee, S. Brown, D. Higgins.

DATE OF ESTABLISHMENT

The operation started in July 1971 and became commercial in 1975. SPECIES AND NUMBERS

C. niloticus:

Stock held in Sanuary 1982 (19)

\section{Hatchlings} 3408

Slaughter stock

Breeding stock

Total
1518
Stock held in December 1982 (68)

Hatchlings 1934

Rearing 2719

Breeding $\quad 70$

Total
70
723 
PRODUCTION AND TRADE (68)

Product

Skins

Live Animals

( 3 years old)

Live Animals

( 12 years old)
1982

Date of production 1982

1982
Quantity

128

128

13

\section{Destination}

France

South African croc. farmers.

South African croc. farmers.

Meat from the crocodiles is also utilised (81). SOURCE OP ANIMALS

In 1982593 hatchlings were produced from eggs of wild origin. See also General Information, above.

Animals taken from the wild:

Year Country in which taken

Form \& number taken
Adults Juveniles Eggs

Survival rate taken

1980

1981

1982

Zimbabwe

1983

zimbabwe

Zimbabwe

30

$0 \quad 0$

1868

1296

748

1053

\section{Adults Eggs}

\begin{tabular}{rrr}
3 & 1569 & \\
0 & 1024 & \\
1 & 688 & $(81)$ \\
& \multicolumn{2}{c}{$(66)$}
\end{tabular}

\section{BREEDING}

900 animals were obtained from Sengwa Mouth Rearing Station in 1982.

The breeding stock consists of 41 ranch-reared animals and 29 problem animals (68).

Total production of eggs laid on the farm was as follows (66):

$\begin{array}{lll}\text { Year } & \text { No. laid } & \begin{array}{l}\text { Hatching } \\ \text { success }\end{array} \\ 1979 & 1341 & 69.88 \\ 1980 & 1499 & 67.28 \\ 1981 & 1895 & 72.68 \\ 1982 & 1790 & 75.88 \\ 1983 & 1819 & 74.38\end{array}$

See also General Information, above. HUSBANDRY

The ranch has rearing and breeding ponds; the rearing ponds are of concrete and the breeding ponds are of earth and are positioned on a natural stream bed. The enclosures have cement-block walls and a security fence (68). Mortality of animals in excess of one year-old averaged 30.28 from 1980 to 1983. Hatchling mortality averaged $60.7 \%$ over the same period (66).

PINANCES

Private (68). Entrance fees paid by tourists to view the crocodiles are an important part of the total income. Handicraft and curio shops at the ranch are supplied by local craftsmen (179).

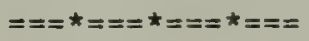

NAME OP OPERATION

Sengwa Mouth Rearing Station

Sengwa Mouth, Lake Kariba.

Operator: R. Van Der Riet. 
DATE OP ESTABLISHMENT

October 1977.

SPECIES AND NUMBERS

C. niloticus:

Stock held in January 1982 (19)

Hatchlings 1925

Slaughter stock 4339

Breeding stock 0

Total 6264

PRODUCTION AND TRADE (68)
Product

Skins

Live Animals

(hatchlings)
Date of production

1982

1982
Stock held in December 1982

Hatchlings 3312

Rearing

Breeding

Total

5112

83

8507

\section{Quantity $\quad$ Destination}

575

France

Spencer Creek croc. Farm, Zimbabwe.

SOURCE OR ANIMALS

The ranch holds ten problem animals which are included in the breeding stock figures above (68).

The numbers of eggs collected and the hatching success are given below $(66)$ :

Year No. collected

$$
1979
$$

1980

1981

1982

1983
2067

2145

2079

3854

3572
Hatching

\section{success}

96.08

96.98

94.68

85.98

91.28

See also General Information, above. BREEDING

In December 1982 the ranch's breeding stock consisted of 73 immature, ranch-reared animals as well as the 10 problem animals (68).

See also General Information, above. HUSBANDRY

Mortality of animals in excess of one year-old averaged 1.98 from 1980 to 1983. Hatchling mortality averaged $13.3 \%$ over the same period (66).

PINANCES

Private $(68)$.

$==+*==+*==+*===$

Basic details of a sixth farm were given by G. Child (66):

NAME OR OPERATION

McIlwaine/Harare area.

Operator: V.H. Bristow.

DATE OP ESTABLISHMENT

November 1983

SPECIES AND NUMBERS

C. niloticus: 


\section{$\underline{\text { References }}$}

1. Achaval, F. (1983). In litt. 10 November.

2. Aftab Alam, S. (1979). In litt. to J. Berney, 23 september.

3. Aftab Alam, S. (1980). In litt. to J. Berney, 5 January.

4. Alcala, A.C. (1984). In litt. to A.K.C. Fernhout, 5 september.

5. Alcala, A.C.. Ross, C.A. and Alcala, E.L. (in press). Aspects of reproduction in captive Crocodylus mindorensis schmidt.

6. Alvarez, J.B. (1983). In litt. 29 March.

7. Andau, P.M. (1984). In litt. 24 January.

8. Anon. (1977). Comprehensive Action Programme for the

Conservation of Crocodiles. Draft Project 3 : Conservation of

Caiman latirostris in Uruguay, Argentina and Southern Brazil. IUCN/SSC Crocodile Specialist Group.

9. Anon. (1978). Conservation of reptiles backed by industry part 2. Leather (November): 37.

10. Anon. $(1979)$. Croc it to me. The Singapore Visitor February 17 March 2.

11. Anon. (1979). Leather (December).

12. Anon. (1979). The crocodile: a vanishing or a developing resource. Leather (April): 63-66.

13. Anon. (1980). Crocodile expert supports NT farming plan. Australian Fisheries (April): 16.

14. Anon. (1980). IUCN/SSC Crocodile Specialist Group Newsletter No.18.

15. Anon. (1980). Shin Min Daily News 11 March.

16. Anon. (1980). brochure of Applied Ecology Pty Ltd.

17. Anon. (1982). Aprovechamiento Racional de la Baba o Babo (Caiman crocodilus). Ministerio del Ambiente y los Recursos Naturales Renovables, Venezuela.

18. Anon. (1982). Zambia's crocodile farm. The Standard (Zambia) 21 May.

19. Anon. (1983). Amendments to Appendices I and II of the

Convention. Proposals submitted pursuant to Resolution Conf. 3.15 on ranching. Transfer from Appendix 1 to Appendix 2 of the Zimbabwe population of Crocodylus niloticus. (submitted to the Fourth meeting of the Conference of the Parties). CITES Document Doc 4.39. Annex 5 .

20. Anon. (1983). Breeding success at crocodile farm. WWF Month1y Report September.

21. Anon. (1983). IUCN/SSC Crocodile Specialist Group Newsletter $2(1): 8$.

22. Anon. (1983). Managing tropical animal resources. Crocodiles as a resource for the tropics. National Research Council. National Academy Press, Washington D.C.

23. Anon. (1983). Measures to save the Yangtze crocodile. (In Chinese) Po-Wu $4: 35-36$.

24. Anon. (1984). 9 crocodiles already dead at new farm. Voice of Nature (Bogor) 22: 4 .

25. Anon. (1984). Annual report of Florida alligator farmers. Florida Game and Freshwater Fish Commission files.

26. Anon. (1984). Asia-Pacific Forestry Commision country reports Philippines. Tigerpaper 11(2): 11-13.

27. Anon. (1984). Crocs off to Japan. Northern Territory News 8 October. 
28. Anon. (1984). Kenya plans a home for 20,000 crocodiles. New York Times 4 May.

29. Anon. (1984). Nang Fang Ribao (People's Rebublic of China), 10 April.

30. Anon. (1984). Proposal to transfer the African population of Crocodylus niloticus from Appendix I to Appendix II, submitted to the 5 th meeting of the Conference of the Parties to CITES by the Republic of Malawi.

31. Anon. (1984). Proposal to transfer the Mozambican population of Crocodylus niloticus from Appendix I to Appendix II, submitted to the 5 th meeting of the Conference of the Parties to CITES by the People's Republic of Mozambique.

32. Anon. (1984). Proposal to transfer from Appendix I to Appendix II the Indonesian population of estuarine crocodile, Crocodylus porosus, submitted to the 5 th meeting of the Conference of the Parties to CITES by the Republic of Indonesia.

33. Anon. (1984). US Fish and Wildlife Service, Endangered species Permit; receipt of applications. Federal Register 49(91): 19744.

34. Anon. (1984). USAID co-financing grant proposal. Crocodile conservation and industry development in Irian Jaya; preparatory phase I consultancy, $8 \mathrm{pp}$.

35. Anon. (1985). Animal house. Time Magazine (April 1): 32.

36. Anon. (1985). Crocodile farming in North Sumatra. Voice of Nature 25(January): 18.

37. Anon. (undated). Tan Moh Hong Reptile Skin and Crocodile Farm. Publicity brochure, 2 pp.

38. Arnold, P.H.S. (1983). In litt. 31 May.

39. Arnold, P.H.S. (1983). In litt. 3 August.

40. Ashley, J.D. (1980). Crocodilian farming: past, present and future. Paper presented to the society for the study of Amphibians and Reptiles (USA) and to a meeting on crocodile conservation of the International union for Conservation of Nature and Natural Resources, Gainesville, Florida, USA.

41. Ashley, J.D. (1982). Marketing opportunities and problems for crocodilian products. Paper presented to the symposium on crocodile conservation and utilisation, Victoria Falls, Zimbabwe. Abstracted in Singh, L.A.K. (1984).

42. Assouad, F. (1984). In litt. to CITES Secretariat, 23 March. 43. Balarin, J.D. (1984). In litt. 8 November.

44. Behler, J.L. and Brazaitis, P. (1982). The Chinese Alligator, its status and propagation in captivity. Zoologische Garten N.F. Jena 2: 73-77.

45. Behler, J.L. and Joanen, T. (1982). Captive management of the Chinese Alligator, Annual Proceedings 1982 of the American Association of Zoological Parks and Aquariums.

46. Bejarano, G.B. (1982). Actual status in the commercialisation of crocodile skins from Bolivia. Proposal to transfer Caiman crocodilus yacare from Appendix II to Appendix I, submitted to CITES, TRAFFIC (USA), 19 July, Appendix I.

47. Bejarano, G.B. (1983). In litt. 4 April.

48. Ben-Moshe, G. (1982). Acclimatization of the American alligator in Israel. Paper presented to the 6 th working meeting of the IUCN/SSC Crocodile Specialist Group, Victoria Falls, Zimbabwe.

49. Ben-Moshe, G. (1983). In litt. November.

50. Berney, J. (1983). In litt. 13 May.

51. Bishaw, A. (1984). In litt. to J.D. Ovington, 2 March. 
52. Blake, D.K. (1981). A report on the possible uses of crocodilians of the Ivory Coast 1981. Unpublished report.

53. Blake, D.K. (1982). Crocodile ranching in Zimbabwe, The Zimbabwe Science News $16(9)$.

54. Blake, D.K. (1984). Pers. comm.

55. Blake, D.K. (1984). Status, conservation and utilization of the Nile Crocodile in Zimbabwe. Paper presented to the 7 th working meeting of the IUCN/SSC Crocodile Specialist Group, Caracas, Venezuela.

56. Blohm, T. (1984). Pers. comm.

57. Blouch, R.A. (1984). Report on a visit to Thailand, 24-30 May 1984. WWF Unpublished report, $7 \mathrm{pp}$.

58. Bolton, M. (1984). Crocodile management in Ethiopia. F.A.O. Report TCP/ETH/2307.

59. Bolton, M. and Laufa, M. (1982). The crocodile project in Papua New Guinea. Biological Conservation 22: 169-179.

60. Bond, T.C. (1983). In litt. 6 september.

61. Boonsong Lekagul (1981). Wildife resources for rural community development. Tigerpaper 8(3).

62. Brooks, H.W. (1983). In litt. $6 \mathrm{July.}$

63. Caughley, G. (1980). Crocodiles in Burma. FAO Report.

64. Chabreck, R.H. (1982). Crocodile management programmes in cuba. F.A.O. Unpublished report, $8 \mathrm{pp}$.

65. Chandler, J.L. (1983). In litt. 15 April.

66. Child, G. (1985). Management of Nile crocodiles in zimbabwe. Paper presented at the technical conference on crocodile conservation and management, Darwin, 14-18 January.

67. Cook, B. (1985). In litt. 3 March.

68. Cumming, D.H.M. (1983). In litt. 18 March.

69. Darazs, M. (1983). In litt. 6 September.

70. Davidar, M. (1983). Hamadryad : Newsletter of the Madras Snake Park Trust $8(3): 24-25$.

71. De Alwis, L. (1983). In litt. 7 March.

72. De Lanessan, C. (1983). In litt. 29 October.

73. De Vos, A. (1984). Crocodile conservation in India. Biological Conservation 29: 183-189.

74. Dieh1, K. (1983). In litt. 22 February.

75. Dogbe-Tomi, A.K.H. (1983). In litt. 23 December.

76. Donadio, A. (1982). Wildlife legislation and enforcement in Colombia. TRAFFIC (USA) Newsletter $4(3 \& 4)$.

77. Fall, Abdoul 0. (1983). In litt. 24 March.

78. Fallas, C.F. (1983). In litt. 29 March.

79. Fuchs, K.-H. (1983). Crocodile farming and ranching in Taiwan. IUCN/SSC Crocodile Specialist Group Newsletter 2(2): 13.

80. Gee, R. (1982). Some comparisons between crocodile farming and crocodile rearing in zimbabwe. Paper presented to the symposium on crocodile conservation and utilisation, Victoria Falls, Zimbabwe. Abstracted in Singh, L.A.K. (1984).

81. Gee, R.E. (1983). In litt. 23 May.

82. Gittens, C. (1985). Cash crocs. Farmers Weekly (South Africa) (January 18): 34-36.

83. Goodwin, T.M. (1983). In litt. $22 \mathrm{July.}$

84. Goudie, G.S. (1983). In litt. 12 August.

85. Goudie, G.S. (1984). Pers. comm.

86. Graham, A. (1983). In litt. 26 September.

87. Graham, A. (1983). In 1itt. 24 october. 
88. Graham, H.D. (1983). In litt. 14 June.

89. Groombridge, B. (1982). The IUCN Amphibia - Reptilia Red Data Book, Part 1. IUCN, Gland, Switzerland, $426 \mathrm{pp}$.

90. Habiyaremye, L. (1984). In litt. 5 January.

91. Haller, R.D. (1983). In litt. 30 March.

92. Harrison, G.H. (1981). Raising crocs, not cane. Animal Kingdom (June/July): 27-29.

93. Heinson, O. (1984). Hothouse crocs. South African Digest 20 April.

94. Hemley, G. and Caldwell, J.R. (1984). The crocodile trade since 1979. Paper presented to the $7 \mathrm{th}$ working meeting of the IUCN/SSC Crocodile Specialist Group, Caracas, Venezuela.

95. Herrera, O. (1985). In litt. 27 June.

96. Hines, T., Abercrombie, C., Percival, F. and Woodward, A. (1984). Florida alligator: economics, harvest and conservation. Paper presented to the 7 th working meeting of the IUCN/SSC Crocodile Specialist Group, Caracas, Venezuela.

97. Hollands, M. (1984). In litt. 14 February.

98. Huang Chu-chien, (1983). In litt. December.

99. Huertas, H. (1985). 5000 crocodiles au pied des centrales nucléaires. Le Matin 21 May.

100. Hunt, R.H. (1984). Pers. comm.

101. Huxley, C.R. (1985). Pers. comm.

102. Inskipp, T.P. (1984). Pers. comm.

103. Joanen, T. (1984). In litt. 29 November.

104. Joanen, T. and McNease, L. (1982). Louisiana alligator farming research programme. The Zimbabwe Science News 16(a): 202-203.

105. Joanen, T. and McNease, L. (1978). Status of Louisiana alligator farm program. Paper presented to the meeting of the IUCN/SSC Crocodile Specialist Group, Madras.

106. Joanen, T. and McNease, L. (1984). Louisiana's alligator conservation program; management of a valuable renewable resource, 1972-1983. Paper presented to the 7 th working meeting of the IUCN/SSC Crocodile specialist Group, Caracas, Venezuela.

107. Joanen, T., McNease, L., Tarver, J. and Behler, J. (1981). Captive propagation of alligators in Louisiana, Paper presented at International Herpetological Congress, October 1-8, 1981, Oxford, England.

108. Katalihwa, M. (1983). In litt. 21 April.

109. Keller, D.R. (1983). In litt. 17 June.

110. Keller, D.R. (1983). In litt. 5 August.

111. Kelly, N.H. (1983). In litt. 6 September.

112. King, F.W., Campbel1, H.W., Messel, H. and Whitaker, R. (1979). Review of the status of the estuarine or saltwater crocodile, Crocodylus porosus. Unpublished report.

113. Kirk, I.A. (1983). In litt. 6 september.

114. Kuhlmann, J. (1983). In litt. 10 June.

115. Kwapena, N. and Bolton, M. (1980). The national crocodile project in Papua New Guinea. A summary of policy and progress. Unpublished report.

116. Kyle, R.A.M. (1983). In litt. 31 August.

117. Lau, S.K. (1984). Crocodile meat for dinner, anyone? Sunday Tribune (Sarawak), 15 January.

118. Lazcano-Barrero, M.A. (1984). Mexico. IUCN/SSC Crocodile Specialist Group Newsletter $3(2): 9-10$. 
119. Le François, R. (1974). L'élevage du crocodile du Nil; résultats d'une expérience préliminaire practiquée au Tchad. Centre

Technique Forestier Tropicale, Notes et documents sur la pêche et la pisciculture. Nouvelle Série, No, 8 (March 1974): 13-38.

120. Lee Toh Ming (1985). In litt. $17 \mathrm{July.}$

121. Lever, J. $(1980)$. Crocodile conservation and industry development in Irian Jaya. Report on consultancy, sponsored by FAO, prepared for the Directorate of Nature Conservation, Directorate General of Forestry, Bogor, Indonesia, 53 pp.

122. Lever, J. (1983). In litt. November.

123. Magnusson, W.E. (1984). Economics, developing countries, and the captive propagation of crocodilians. Wildlife Society Bulletin 12: $194-197$.

124. Marsh, C.W. (1985). A resurvey of Tana River primates. Institute of Primate Research, Kenya. Unpublished report, 27 pp.

125. Maskey, T.M. (1983). In litt. December.

126. Medem, F. (1980). Caimans and crocodiles - a tale of destruction. Oryx 15(4): 390-391.

127. Medem, F. (1980). Sanctioned exportation of caiman hides from Colombia. TRAPFIC (International) Bulletin 2(9\&10): 95-96.

128. Medem, F. (1983). In litt., 12 April.

129. Morgan, D.R. (1983). In litt. December.

130. Moya, R. (1975). Los crocodrilos de Guama. Technica Pesquera $7(92)$.

131. Mukherjee, S.K. (1983). In litt. 9 March.

132. Nash, N. (1983). In litt. 13 April.

133. Onions, J.T.V. (1982). Crocodile farm project- Edward River, Queensland, Australia. Proceedings of the 5 th Working Meeting of the Crocodile Specialist Group of the Species Survival Commission of the International Union for Conservation of Nature and Natural Resources convened at Florida State Museum, Gainesville, Florida U.S.A. 12-16 August 1980.

134. Onions, J.T.V. (1983). In litt. I December.

135. Ottenwalder, J.A. (1983). In litt. to F. Wayne King, 22 July.

136. Parisot, T.J. (1985). In 1itt. 24 January.

137. Parker, F. (1981). New crocodile laws for Papua New Guinea. Wildlife in Papua New Guinea, Wildlife Publication $81 / 1$, Division of Wildlife, Konedobu, $50 \mathrm{pp}$.

138. Parker, G. (1983). In litt. 2 December.

139. Parker, G. (1984). In litt. 17 February.

140. Penzhorn, H.O. (1983). In litt. 6 september.

141. Perkins, E.D. (1983). In litt. 17 June.

142. Petocz, R. (1983). In litt. 20 December.

143. Petocz, R. (1984). In litt. 25 August.

144. Pfotenhauer, L. $(1984)$. Maun's new crocodile farm. Kutlwano (November): $18-20$.

145. Pooley, A.C. (1980). In litt. to R.S.R. Fitter, Fauna and Flora Preservation Society, London, 2 January.

146. Pooley, A.C. $(1980)$. In litt, to S. Bennet, 8 February.

147. Pooley, A.C. (1981). In litt. 5 March.

148. Pooley, A.C. (1983). Pers. comn.

149. Pooley, A.C. $(1984)$. In litt. to C.R. Huxley 24 July.

150. Pow Chong, G. (1985). Crocodiles everywhere but there are no tears. Sunday Times (Singapore) 13 January.

151. Quaino, B.A. (1983). In litt. 21 November. 
152. Quero de Pena, M. (1984). Wildlife administration policies with respect to the experimental commercial exploitation of the spectacled caiman (Caiman crocodilus) in the Venezuelan Llanos. Paper presented to the 7 th working meeting of the IUCN/SSC Crocodile Specialist Group, Caracas, Venezuela.

153. Ranot, S. (1984). Pers. comm.

154. Rebêlo, G.H. (1984). Pers. comm.

155. Reichart, H.A. (1979). In litt. to N. Duplaix, 23 October.

156. Reti, I. (1983). In litt. 21 March.

157. Rubini, A. (1984). In litt. $26 \mathrm{July.}$

158. Salter, R.E. (1983). In litt. 21 July.

159. Sanogho, N.N. (1983). In litt. 5 April.

160. Saunders G.W. (1983). In litt. 13 September.

161. Saunders, G.W. (1983). In litt. to J.D. Ovington, $18 \mathrm{July}$.

162. Seaman, J.J. (1983). In litt. 3 August.

163. Shirazi, K. (1983). In litt. 13 August.

164. Shuja, J.D. (1985). In litt. 1 March.

165. Singh, L.A.K. (1983). In litt. 26 April.

166. Singh, L.A.K. (1984). Developments in crocodilian management and research. India: Establishment of the Wildlife Institute of India. F.A.O. Field Document No. 1. FO: IND/82/003, $123 \mathrm{pp}$.

167. Singh, L.A.K., Kar, S. and Choudhury, B.C. (1984). Indian crocodilians: a 10-year review of management. Paper presented to the 7 th working meeting of the IUCN/SSC Crocodile specialist Group, Caracas, Venezuela.

168. Slogrove, M. (1983). Pers. comm.

169. Soepangkat, S. (1985). In litt. 9 April.

170. Sondhi, R. (1984). Pers. comm.

171. Stewart, G.R.C. (1983). In litt. 6 september.

172. Suvanakorn, P. (1985). In litt. to CITES secretariat, 10 June.

173. Suvanakorn, P. and Youngprapakorn, C. (Undated). The breeding of crocodiles in captivity at Samutprakan, Thailand.

174. Tan Chye Hock, R. (1984). In litt. 11 September.

175. Tello, J.L. (1983). Mozambique's cropping scheme in the zambezi Delta Area. Report presented to 59 th SSC meeting of the International Union for Conservation of Nature, Harare, Zimbabwe, 16 April 1983.

176. Tello, J.L. (1985). CITES Consultancy report on Nile crocodile Crocodylus niloticus. Annex to the "Proposal to transfer Crocodylus niloticus from Appendix I to Appendix II and to allow legal trade with set quotas", submitted to the 5 th meeting of the Conference of the Parties to CITES.

177. Tsai, Yih-Hsiung (1984). In litt. 20 september.

178. Tsai, Yih-Hsiung (1984). In litt. 9 November.

179. Van Jaarsveldt, K.R. (1982). The present trade in skins of Crocodylus niloticus ranched and reared in zimbabwe. Paper presented to the 6 th working meeting of the IUCN/SSC Crocodile Specialist Group, Victoria Falls, Zimbabwe.

180. Van Jaarsveldt, K.R. (1983). In litt. 14 February.

181. Van Jaarsveldt, K.R. (1983). In litt. 9 June.

182. Van Jaarsveldt, K.R. (1983). In litt. 30 september.

183. Van Jaarsveldt, K.R. (1984). In litt. $20 \mathrm{July.}$

184. Van Jaarsveldt, K.R. and Van Jaarsveldt, A.B. (1983). In litt. 26 April.

185. Varona, I.s. (1980). Protection in Cuba. Oryx 15(3): 284. 
186. Vliet, K.A. (1984). In litt. 26 october.

187. Waithman, J. (1983). In litt. 18 May.

188. Wallis, B.E. (1980). Marketing assistance programme for agricultural products from least developed countries. Market prospects for reptile leathers. UNCTAD/GATT International Trade Centre ITC/DIP/12.

189. Watanabe, M.E. (1983). In litt. 29 August.

190. Watanabe, M.E. (1983). The Chinese alligator: is farming the last hope? oryx 17(3): 176-181.

191. Watanabe, M.E. and Huang Chu-Chien (1982). Status of the Chinese alligator in the People's Republic of China. Paper presented to the 6 th working meeting of the IUCN/SSC Crocodile specialist Group, Victoria Falls, Zimbabwe.

192. Webb, G., Manolis, S., Whitehead, P. and Letts, G. (1984). A proposal for the transfer of the Australian population of Crocodylus porosus Schneider (1801) from Appendix I to Appendix II of CITES. Conservation Commission of the Northern Territory, $82 \mathrm{pp}$. Proposal submitted to the 5 th meeting of the Conference of the Parties to CITES.

193. Whitaker, R. (1974). Notes on behaviour, ecology and present status of the marsh crocodile (Crocodylus palustris) in south India. World Wildlife Pund Project No. 631 .

194. Whitaker, R. (1980). Interim report on the status and biology of crocodiles in Papua New Guinea. FAO/UNEP Project PNG/74/029, Field Document No. 1.

195. Whitaker, R. (1980). Report on a visit to crocodile and alligator facilities in USA, JulY-August 1980. Unpublished report.

196. Whitaker, R. (1981). Crocodile farming and management in Mozambique. FAO Project working document MOz/76/007, 23 pp.

197 Whitaker, R. (1982). Crocodile conservation in India. The Zimbabwe Science News $16(9): 211-213$.

198. Whitaker, R. (1982). Export prospects from commercial crocodile farms in Bangladesh. International Trade Centre/UNCTAD/GATT, DOC. ITC/DIP/63.

199. Whitaker, R. (1984). Multiple clutching: conservation and commercial implications. Unpublished report, Madras Snake Park Trust.

200. Whitaker, R. (1984). Preliminary survey of crocodiles in Sabah, East Malaysia. Report prepared for WWF Malaysia and the Game Branch, Forest Department, Sabah, IUCN/WWF Project no. 3127, 69 pp.

201. Whitaker, R. (1984). Status of Asian crocodilians: an update. Unpublished report, Madras Snake Park Trust.

202. Whitaker, R. (1984). The International Crocodile Bank. Unpublished report, Madras Snake Park Trust.

203. Whitaker, R. and. Whitaker, 2. (1981). In litt. to B. Groombridge, 10 April.

204. Whitaker, R., Hartono, C. and Sukran, P. (1985). Crocodile farming prospects in Irian Jaya. WWF Monthly Report (April): 83-85.

205. Wilson, J. (1985). In litt. 25 January.

206. Yates, K. (1982). Minutes of the Zimbabwe Crocodile Rearers meeting, 18 March.

207. Yi Lee Kong (1984). Crocodile farming. The Star Section 2, (Penang), 9 October. 
208. Youngblood, R. (1976). Baby crocodiles become big business. Jakarta, December, Unpublished report.

209. Youngprapakorn, C. (1983). In litt. 21 March.

210. Youngprapakorn, C. (1983). In litt. 23 May.

211. Youngprapakorn, c. (1983). In litt. 27 October.

212. Youngprapakorn, U. (undated). The biggest crocodile farm in the world. (brochure), Samutprakan Crocodile Parm. 



4 